Review

\title{
Regulation of CAR and PXR Expression in Health and Disease
}

\author{
Martine Daujat-Chavanieu $(\mathbb{D}$ and Sabine Gerbal-Chaloin * \\ IRMB, University of Montpellier, INSERM, CHU Montpellier, 34295 Montpellier, France; \\ martine.daujat@inserm.fr \\ * Correspondence: sabine.gerbal-chaloin@inserm.fr
}

Received: 28 September 2020; Accepted: 28 October 2020; Published: 31 October 2020

check for updates

\begin{abstract}
Pregnane $X$ receptor (PXR, NR1I2) and constitutive androstane receptor (CAR, NR1I3) are members of the nuclear receptor superfamily that mainly act as ligand-activated transcription factors. Their functions have long been associated with the regulation of drug metabolism and disposition, and it is now well established that they are implicated in physiological and pathological conditions. Considerable efforts have been made to understand the regulation of their activity by their cognate ligand; however, additional regulatory mechanisms, among which the regulation of their expression, modulate their pleiotropic effects. This review summarizes the current knowledge on CAR and PXR expression during development and adult life; tissue distribution; spatial, temporal, and metabolic regulations; as well as in pathological situations, including chronic diseases and cancers. The expression of CAR and PXR is modulated by complex regulatory mechanisms that involve the interplay of transcription factors and also post-transcriptional and epigenetic modifications. Moreover, many environmental stimuli affect CAR and PXR expression through mechanisms that have not been elucidated.
\end{abstract}

Keywords: CAR; PXR; regulation; expression

\section{Introduction}

Pregnane $X$ receptor (PXR, NR1I2) and constitutive androstane receptor (CAR, NR1I3) are members of the nuclear receptor superfamily that mostly includes ligand-activated transcription factors. Their activity has long been associated with the regulation of drug metabolism and disposition through drug metabolizing enzyme and transporter (DMET) expression modulation [1,2]. It is now well established that PXR and CAR participate in the regulation of physiological and pathological conditions and are implicated in disease development [3,4]. PXR is involved in drug metabolism, bile acid and cholesterol metabolism, inflammation, and cancer. Its more flexible ligand-binding pocket, compared with that of other nuclear receptors, explains the wide spectrum of structurally diverse ligands [5]. CAR can modulate the fate of glucose, lipids, and bile acids, and it is also involved in cell cycle regulation and chemical carcinogenesis. Unlike PXR, CAR can be activated through ligand-dependent and also ligand-independent mechanisms [6].

Considerable efforts have been made to understand PXR and CAR activity regulation, mainly by their cognate ligand(s); however, additional regulatory mechanisms influence their activity (for instance, through regulation of their expression). This aspect has been poorly investigated; thus, in this review we present the data generated in several species and organs on CAR and PXR expression regulation in physiological and pathological conditions. 


\section{CAR and PXR Expression during Development}

Little is known on CAR and PXR expression during embryonic and fetal development. In rat liver, Pxr mRNA levels are between 2.4 and $6.2 \%$ of the adult levels from embryonic day (E) 17 to E21, and $20 \%$ of the adult level at day 1 after birth [7]. This level rises gradually to $80 \%$ of the adult values by week 4 after birth. The nuclear expression level and activity of the PXR protein at E20 are about $40 \%$ of the adult value, suggesting posttranscriptional regulation [7]. During the postnatal period, there is a gradual increase in PXR protein amount, as observed for Pxr mRNA [7]. These findings were confirmed by a systematic analysis of the expression of nuclear receptors and their target genes, including cytochrome P450 enzymes (CYPs) in rat during in utero development, birth, neonatal age, weanling, puberty, adulthood, and aging. Specifically, the mRNA expression of Car and Pxr reaches a plateau at day 28 (beginning of puberty) [8]. Unlike Pxr, Car expression strongly decreases at day 800 of life. It has been shown that miR-137 inhibits Car expression in mouse neonatal liver. In newborn and adult mice, miR-137 and Car expression levels are inversely correlated, suggesting a miR-137 role in Car expression regulation at birth [9].

In calves, the abundance of CAR and PXR mRNA progressively increases from birth to day 5 and day 159 , while that of their partner retinoic $X$ receptor $(R X R \alpha)$ remains constant [10]. In the marine flatfish Solea senegalensis, sspxr 1 mRNA expression is first detected at $18.5 \mathrm{~h}$ post-fertilization and its level increases until day 3 post-hatch (dph) [11]. Then, ssprx 1 expression remains low until the onset of metamorphosis ( $9 \mathrm{dph}$ ), but increases progressively during pre-metamorphosis, reaching the highest levels in larvae after metamorphosis (20 dph) [11].

In humans, Funakoshi et al. [12] found that CAR and PXR mRNA expression levels at 20 and 23 weeks of gestation represent $0.2 \%$ and $3.8 \%$, respectively, of those observed in adult liver. This suggests very low expression levels in human liver at mid-gestation. Betts et al. also found similar expression levels and showed that they were strongly correlated with CYP3A7 and CYP3A4 mRNA expression [13]. As observed in rodents, in human liver tissue samples (fetal, neonatal, young, middle-aged, and elderly), PXR mRNA expression is low at the fetal and neonatal stages, increases up to middle age [14], and then decreases to fetal levels in the elderly [15]. In liver, CAR mRNA level is relatively high late in the first trimester and early in the second trimester (to gestational day $\approx 137$ ), although these levels are approximately 100-fold lower than those measured in adult liver [14].

PXR mRNA is also detected in fetal intestine (5 to 12 gestational weeks) at levels comparable to those in fetal liver. Surprisingly, $C A R$ expression in fetal intestine is much higher than in liver $\left(\times 10^{8}\right)$. $P X R$ and CAR mRNA are detected in fetal adrenal gland, but their expression is much lower than in intestine and liver [15].

Stem cell differentiation to hepatocyte-like cells (HLC) is used to reproduce liver development in vitro, and one of the most studied end-points is detoxication [16]. CAR and PXR are upregulated during stem cell differentiation, but to levels much lower than those observed in primary hepatocytes [17]. Gene copy number analysis showed that CAR mRNA expression during human embryonic stem cell differentiation toward HLC reaches values close to those detected in liver during the first gestational trimester. Conversely, PXR mRNA remains almost undetectable [12,14].

PXR and CAR do not seem to have essential developmental roles in mammals. Indeed, PXR [18] and CAR [19] knock-out (KO) mice are phenotypically normal, unless challenged with potential toxic compounds. Moreover, the liver expression of CAR and PXR remains low during fetal and neonatal life. They expression reaches a plateau at puberty, suggesting a role of sexual hormones in the regulation of their expression. Kennedy et al. proposed that growth and/or sex hormones that control sexual dimorphism $[20,21]$ may act as biochemical regulators of DMET activity via interaction with CAR and PXR [22]. The effect of growth/sex hormones on CAR and PXR expression has been poorly explored.

\section{PXR and CAR Tissue Distribution}

PXR tissue distribution was first studied by Zhang et al. in the rat in 1999 [23]. They found that rat Pxr is expressed in liver; intestine; and to a lower extent in kidney, lung, and stomach. However, 
they could not detect any expression in spleen, heart, brain, and testis [23]. A tissue-specific mRNA expression profile analysis of human nuclear receptors showed that $P X R$ is abundant in liver, $\approx 10$ times less abundant in small intestine and colon, and $\approx 100$ times less abundant in stomach and skeletal muscle [24]. In the mouse, Pxr expression varies along the intestine; it is similar to that of liver in jejunum, ileum, cecum, and colon, but lower in duodenum [25]. In the pig, PXR mRNA level is high in liver, small intestine, heart, kidney and colon [26]. In fish, pxr mRNA expression presents similarities with the distribution observed in mammals, with higher levels in liver and intestine [11,27]. The high expression level of PXR in the enterohepatic system explains its crucial role as a sensor of environmental cues [28].

Data are limited on CAR tissue distribution. In the Protein Atlas database (https://v18.proteinatlas. org/), human CAR mRNA is predominantly expressed in liver and to a lesser extent in small intestine, duodenum, and kidney, but also in brain, skin, and lung. Human CAR mRNA is also detected in colon and the Caco2 cell line (human colorectal adenocarcinoma), whereas mouse CAR protein is present in colon and ileum [29]. Low CAR mRNA expression has been described in rat and human lung, but is absent in rabbit and mouse lung [30-32].

In mouse liver, $P x r$ and Car are strongly expressed in hepatocytes [33]. Moreover, Car expression is significantly higher in tetraploid $(4 \mathrm{~N})$ than octoploid $(8 \mathrm{~N})$ hepatocytes [34]. PXR mRNA is detected in primary human Kupffer [35] and stellate cells [36]. Conversely, it is absent, like Car, in primary female mouse Kupffer and endothelial cells [33]. PXR and CAR mRNA are also detected in human circulating blood cells, CD4+ and CD8+ T cells, CD19+ B cells, and primary CD14+ monocytes [37,38]. PXR is also observed in the THP1 cell line (acute monocytic leukemia) [35], in mouse peritoneal macrophages [39], mesenteric adipose tissue [40], and calvaria osteoblasts [41]. PXR and CAR expression profiles in placenta and brain have been reviewed recently [42,43].

\section{Splicing Variants}

Several splice variants of human CAR have been identified [44-46], and they might contribute to CAR functional diversity [47-50]. Among the major splice variants present in human liver, CAR2 and CAR3 are estimated to account for $10 \%$ and $40 \%$ of the total CAR transcripts, respectively [45,51]. Both variants encode proteins that contain short insertions within the ligand-binding domain. Unlike the reference CAR isoform, these variants exhibit low constitutive activity, function as ligand-activated nuclear receptors, and may modulate the activity of the reference CAR isoform. CAR mRNA splicing variants are expressed in brain, kidney, liver, testis, intestine, adrenal gland, bone marrow, skin, and fetal liver, and each of them shows a tissue-specific expression pattern [46,52]. In some of the human CAR isoforms, the functional domains, for instance the ligand binding domain or the zinc fingers necessary to dock to the CAR binding element in DNA, are modified. Thus, it is possible that some CAR splice variants have unique functions that remain to be identified.

A mouse CAR2 variant without the C-terminal portion of the ligand binding/dimerization domain cannot transactivate on its own and does not inhibit transactivation mediated by mouse CAR1 [32]. Five alternatively spliced variants of pig CAR also have been described, each of which generates a truncated protein. The pig CAR splice variant 2 has a dose-dependent dominant negative effect on the activity of the reference CAR isoform [53].

Many PXR gene variants have been described in human liver [46,54,55] and intestine [56] with altered transactivation activity towards target genes. The identification of more than 15 PXR splicing and transcript variants in human liver may contribute to the interindividual variability in DMET expression [54,57]. Recent work has focused on four of these variants. Transcript variant 1 (PXR1) and 2 (PXR2) originate from exon 1a and 1b, respectively, and share exon 2 to exon 9 . They respond to agonists by activating target gene expression. Conversely, PXR3, which lacks part of exon 5 that encodes the ligand-binding domain, does not induce target gene expression, but plays a dominant negative effect on PXR1 transcriptional activity (reviewed in [58]). The small PXR (sPXR) variant encodes a dominant negative PXR isoform of $37 \mathrm{kDa}$ that represses the function of full length PXR 
(51 kDa), likely through competition for cofactors such as steroid receptor coactivator 1. PXR1 and sPXR are downregulated in cancer tissue compared to adjacent normal tissue [59]. The expression profiles of the main PXR variants have not been fully studied. Human PXR variants are expressed in adult and fetal liver, heart, colon, small intestine, stomach, adrenal gland, bone marrow, specific brain regions (thalamus and spinal cord) [55], and in primary and secondary sarcoma cell lines [60]. PXR2 mRNA represents approximatively 6 to $15 \%$ of all PXR transcripts in liver, with high interindividual variability (from $1 \%$ to $60 \%$ ) [55,61]. PXR3 mRNA represents $0.32 \%$ (0 to $3.84 \%$ ) of all human PXR transcripts [55].

Two mouse PXR isoforms were originally described: PXR1 and PXR2. PXR2 shows reduced ligand activation profile compared with PXR1 [57], decreases the basal transcription of CYP3A4, and directly represses PXR1 regulatory effects [62]. Similar to human PXR, the pig PXR gene has multiple splice variants in the ligand-binding domain [26] that represent about 5.3\% of all pig PXR transcripts. None of the pig PXR splice variants is active in a luciferase reporter assay, but two of them significantly increase the transactivation of the reference PXR variant in co-transfection experiments [63].

Additional detailed and comparative mechanistic studies are required to predict the effect of PXR and CAR variant expression in physiological and pathological processes.

\section{Circadian Clock}

Biological rhythms are controlled in part by circadian clocks, i.e., transcriptional mechanisms that synchronize the organism to the daily changes in an anticipatory way. The master clock located in the hypothalamus suprachiasmatic nucleus coordinates all peripheral clocks through neuronal connections and hormonal signals. At the molecular level, circadian clocks comprise a network of genes/transcription factors, including CLOCK and BMAL1, and their target genes period (PER), cryptochrome (CRY), and the orphan nuclear receptor REV-ERB $\alpha$ that forms several cell-autonomous feedback circuits. REV-ERB and retinoic acid receptor-related orphan receptors (RORs) show opposite circadian expression and transcriptional activity [64]. BMAL1/CLOCK heterodimers activate the transcription of clock-controlled genes, including CRY/PER. Consequently, PER and CRY proteins accumulate, inhibit the transcriptional activity of BMAL1/CLOCK, and block their own transcription. Conversely, REV-ERB $\alpha$ represses BMAL expression, whereas RORs induce it $[64,65]$.

CAR and PXR, like many other hepatic transcription factors [66,67], exhibit a peak of mRNA expression around the light/dark transition before the beginning of the active period in animals and in relation to their regular feeding patterns. Therefore, they contribute to the temporal detoxification cycle in liver. However, conflicting findings have been reported, depending on the species and the methodology used to assess whether a gene displays a significant day-night oscillation. For example, according to a cosine-wave pattern algorithm, the nuclear receptors Car, Shp, and Rxr are rhythmically expressed in mouse liver, but not $P x r$ [66]. Other studies reported a clear diurnal variation of mouse Pxr expression [68,69]. In rats, Pxr displays significant daily oscillations. On the other hand, Car mRNA expression tends to be higher in the dark than in the light period [70], whereas it clearly exhibits diurnal difference according to another study [71]. Moreover, the circadian variation of Car, Pxr, and the related Cyp genes is sexually dimorphic, with higher expression reported in female over male mouse liver [21]. Sex hormones and STAT5b mediate differences in growth hormone (GH) secretion patterns between males and females, and together with HNF4 $\alpha$ regulate the sexually dimorphic expression of CYPs and other liver-expressed genes [20], possibly including nuclear receptors.

In mouse liver and small intestine, Car but not Pxr expression is regulated by the circadian PAR domain basic leucine zipper (PARbZip) transcription factors DBP, HLF, and TEF. Ablation of these three genes results in the loss of the rhythmic expression of Car and its target genes and higher sensitivity to xenobiotics. CAR-dependent induction of Cyp2b10 mRNA expression upon exposure to phenobarbital displays a higher circadian accumulation in epithelial intestinal cells (eightfold) compared with hepatocytes [69]. Importantly, the regulation by circadian rhythms of numerous transcriptional regulators of Car expression (see Section 8) may indirectly contribute to the non-transcriptional 
temporal modulation of Car expression. Aryl hydrocarbon receptor (AHR) and its heterodimerization partner aryl hydrocarbon receptor nuclear translocator (ARNT), which regulate CAR levels in mouse and human liver, follow the same rhythmic pattern [72,73]. Similarly, BMAL1 participates in the circadian regulation of $H n f 4 \alpha$ in mice, mainly through action on its P1 promoter [74]. ROR $\alpha$ and ROR $\gamma$ also regulate the circadian transcription of DMET-related genes [75]. PGC-1 $\alpha$ is rhythmically expressed and activates the expression of BMAL1 and REV-ERB $\alpha$ through ROR co-activation [76]. The rhythmic repression of glucocorticoid receptor transcriptional activity mediates glucocorticoid signaling that follows a circadian pattern [77].

Chronic circadian misalignment is sufficient to disrupt the liver clock and circadian metabolism and to drive the development of non-alcoholic fatty liver disease (NAFLD), non-alcoholic steatohepatitis (NASH), and hepatocellular carcinoma (HCC) in mice, independently of dietary, exogenous, or genotoxic stress [78]. For example, conditions that simulate long-term jetlag in mice induce sympathetic nervous system dysfunction and peripheral clock suppression, resulting in the downregulation of Nr1h4 (or Fxr, the gene encoding bile acid receptor), disruption of bile acid homeostasis, and upregulation of Car and transcription factors that stimulate cell proliferation. The transcriptional activation of Car promoter may involve AP1 and CREB factors activated in response to sympathetic nervous system-ADR $\beta$-c-AMP-PKA signaling [78].

\section{Hepatic Functional Zonation}

In the hepatic lobule, hepatocytes are organized in trabeculae and perform different functions depending on their location: periportal (PP) or perivenous (PV). PP hepatocytes are mainly responsible for neoglucogenesis, urea formation, and lipid $\beta$-oxidation. PV hepatocytes are primarily involved in glycolysis, glutamine synthesis, lipogenesis, bile acid synthesis, and drug metabolism. These enzyme gradients are conditioned by blood flow, oxygen and nutrient gradients, paracrine signaling, contact with other cell types, and extracellular matrix composition (reviewed in [79]). The APC/Wnt/ $\beta$-catenin signaling pathway has been identified as the main molecular regulator of liver functional zonation $[80,81]$.

In a global gene expression analysis of PP and PV mouse hepatocytes, following collagenase/digitonin perfusion, Braeuning et al. identified CAR and AHR as PV hepatocyte-enriched proteins [82]. In a mouse model of liver-specific $\beta$-catenin $\mathrm{KO}, \mathrm{Car}$ and Ahr were drastically downregulated in both sexes, whereas Pxr mRNA was slightly reduced only in females [83]. Immuno-histochemistry analysis in rodent and human liver showed that CYP2B and CYP3A, the main CAR and PXR targets, were localized in the PV zone. In liver of $C$ tnnb1 ${ }^{-/-}$mice, Cyp $2 b 10$ expression was strongly induced, while Cyp3a was modestly affected [83]. Conversely, their induction by exposure to pregnenolone $16 \alpha$-carbonitrile was comparable in wild type and $C t n n b 1^{-/-}$animals. This suggests that $\beta$-catenin may regulate Cyp2b10 expression in a direct and indirect manner through CAR expression, but has a modest effect on Cyp3a and Pxr gene regulation. By using mice in which $\beta$-catenin is conditionally activated or ablated, Gougelet et al. demonstrated that the drug and bile metabolism pathways are preferentially targeted by $\beta$-catenin, partly through CAR and AHR. Following $\beta$-catenin activation, transcription factor 4 (TCF-4) and $\beta$-catenin showed strong chromatin occupancy on CAR Wnt-responsive elements (WRE), demonstrating its direct regulation by $\beta$-catenin [84]. Moreover, $\beta$-catenin-TCF/LEF binding activity was identified on the mouse Pxr proximal promoter, but $\beta$-catenin activation cannot upregulate the Pxr promoter activity, suggesting that $\beta$-catenin does not regulate, at least directly, Pxr expression [85].

Data are limited on $\beta$-catenin-mediated regulation of xenoreceptors in humans. In primary human hepatocytes (PHHs), activation of the $\beta$-catenin pathway increases $A H R$ mRNA expression, but has no effect on rifampicin-mediated CYP3A4 induction. This suggests that PXR is not a direct target of $\beta$-catenin, as observed in rodents. CAR expression was not explored in this study [86]. In differentiated HepaRG cells, $\beta$-catenin is required for AHR-, CAR-, and PXR-mediated induction of CYP1A, 
CYP2B6, and CYP3A4, respectively [87]. This effect might be mediated through a synergism between xenoreceptors and $\beta$-catenin activity, rather than through the regulation of xenoreceptor expression.

Mouse liver tumors induced by a single injection of the liver carcinogen $\mathrm{N}$-nitrosodiethylamine (DEN) frequently harbor activating mutations in the Ha-ras or B-raf proto-oncogenes. When DEN is combined with chronic administration of phenobarbital (a liver tumor promoter), tumors show activating mutations in the Ctnnb1 proto-oncogene [88]. Schwartz's group reported that gene expression patterns in mouse liver tumors harboring activating mutations in Ctnnb1 and Ha-ras or B-raf correspond to those of PV and PP hepatocytes, respectively [89]. Car mRNA expression is reduced in Ha-ras and B-raf mutated tumors compared with normal liver, whereas its expression is not affected in Ctnnb1-mutated tumors [90-92]. Despite the reduced Car mRNA expression level in B-raf- and Ha-ras-mutated tumors, $B$-raf-mutated tumors respond with pronounced induction to a CAR activator, as observed in normal tissue, whereas induction is weak in Ha-ras-mutated tumors [92]. This difference could be explained by the strong extracellular signal-regulated kinase (ERK) phosphorylation in Ha-ras-mutated tumors that may reduce CAR nuclear translocation in response to its activators. These data highlight that besides Car expression level, the cell context of activation is very important.

Incubation of mouse primary hepatocytes or 70.4 hepatoma cells with increasing amounts of serum causes a concentration-dependent attenuation of PV markers, whereas the expression of PP markers is increased. Epidermal growth factor (EGF) partly mimics the serum effects in hepatoma cells, and EGF effect can be blocked by ERK inhibitors [93]. By examining the effects of mitogen-activated protein kinase (MAPK) in PHHs, Bachleda et al. observed a strong inhibition of CAR mRNA expression in response to sorbitol, anisomycin, or EGF, while PXR mRNA was much less affected [94]. Transcriptomic analysis showed that $C A R$ is among the most downregulated genes in PHHs incubated with EGF. This downregulation is accompanied by inhibition of CYP2B6 induction mediated by CITCO (a direct CAR activator) and a shift towards PXR-mediated gene regulation [95].

The zonation pattern is regulated in a complex and coordinated manner. Regulation of mouse Car gene expression is controlled by $\beta$-catenin and growth factors, specifically EGF that may participate in CAR PV expression. Nevertheless, due to the lack of good antibodies, CAR protein expression pattern has not been explored in tissue sections. In humans and mice, PXR gene expression is not regulated, at least directly, by EGF and $\beta$-catenin. Like for CAR, PXR zonal expression pattern needs to be investigated in tissues, but this is limited by the poor antibody quality. Single-cell technology, recently used to describe the expression of bile acid metabolizing enzymes, may be a source of information about xenoreceptor expression pattern [96,97].

\section{Nutritional Status and Microbiome Metabolites}

PXR and CAR are involved in the regulation of energy homeostasis [4]. CAR activation improves insulin sensitivity, inhibits lipogenesis and gluconeogenesis, and increases brown adipose tissue energy expenditure [98]. Unlike CAR beneficial effects, PXR activation quite consistently leads to increased hepatic lipid accumulation and promotes the fatty liver phenotype [4]. In agreement, PXR KO improves high-fat diet (HFD)-induced obesity via induction of FGF15 expression, resulting in suppression of bile acid synthesis and reduction of lipid absorption and liver triglyceride levels [99]. PXR gene variants might be associated with disease severity in NAFLD and contribute to progress towards more severe disease stages [100]. However, differences in the mechanisms observed between preclinical models and humans question the physiological relevance of findings in animal models. CAR glucose-lowering effect is consistently found in rodents and humans. Conversely, PXR activation leads to opposite effects on gluconeogenesis in rodents and humans [4].

On the other hand, several studies have indicated that PXR/CAR function and target gene regulation could be controlled by the nutritional status and cellular energy state. Specifically, it has been shown that CAR expression can be induced during the feeding-fasting switch. Fasting and caloric restriction increase CAR expression and activity, and then CAR coordinates the adaptive response by slowing down energy expenditure and weight loss [101]. Fasting and glucagon increase 
cyclic adenosine monophosphate (cAMP) and activate PKA signaling, leading to the induction of peroxisome proliferator-activated receptor coactivator- $1 \alpha$ (PGC- $1 \alpha$ ). PGC- $1 \alpha$ interaction with HNF4 $\alpha$ directly regulates $C A R$ gene expression through an evolutionarily conserved HNF4 response element identified in the mouse and human CAR promoters, leading to an increase of ligand-independent CAR activity [102]. Wieneke et al. described an alternative or concomitant mechanism [103]. Fasting typically increases the plasma level of free fatty acids that are natural ligands of peroxisome proliferator-activated receptor alpha (PPAR $\alpha)$. PPAR $\alpha$ controls the expression of a plethora of genes involved in the lipid metabolic pathway. Consistently, PPAR $\alpha$ is widely expressed in tissues with high fatty acid oxidation rate, such as liver [104]. Incubation of rat hepatocytes with the PPAR $\alpha$ activator WY14643 and experiments in PPAR $\alpha$-deficient mice showed that a PPAR $\alpha$-dependent increase in CAR expression is needed to obtain the full response to starvation $[103,105]$. A conserved DR1 motif in the CAR promoter is necessary and sufficient for this control [103].

Zhang et al. showed that PPAR $\alpha$ ligands, such as clofibrate, increase Pxr transcript level in rat hepatocytes [23]. An in silico analysis of the human PXR proximal promoter identified several putative binding sites for liver-enriched transcription factors [106] that harbor a functional PPAR responsive element (PPRE). Fasting-mediated upregulation of PXR expression and function in mice is mediated at least partially by PPAR $\alpha$ [107]. While PGC- $1 \alpha$ and glucagon increase PXR expression and transactivation function, SIRT1 inhibits PXR coactivation by PGC-1 $\alpha$ [107]. Fasting also results in the differential expression of pxr in the Senegalese sole [11].

Feeding rhythm drives the circadian transcriptional regulation by the liver clock. The microbiome is essential to integrate the hepatic clock genes and the regulation of metabolic gene expression for optimal liver function. Many bacterial metabolites in the colon lumen activate PXR and CAR, such as the tryptophan metabolite indole-3-propionic acid (IPA) and the secondary biliary acids deoxycholic acid and lithocholic acid [108]. The gut microbiome affects the activity and expression of PXR and CAR and also the expression of their target genes. Car and Pxr are upregulated in germ-free mice compared with conventional mice [109-111]. IPA can activate PXR that regulates aorta and pulmonary vascular vasodilatory function through endothelial nitric oxide synthase (eNOS) modulation. IPA supplementation in germ-free mice also increases Pxr mRNA expression in aortic segments, and as an agonist activates PXR to regulate aorta and pulmonary vascular vasodilatory function [112]. Butyrate induces PXR transcription in Caco-2 cells [113]. The intestine microbiota plays a role in the ontogeny and establishment of sexually dimorphic liver metabolism through the regulation of GH secretion and sexual maturation $[110,114]$. The exact mechanism of action of microbiome metabolites remains elusive.

\section{Transcriptional Regulation by Transcription Factors}

PXR and CAR establish a crosstalk with other nuclear receptors or transcription factors to control various signaling pathways (reviewed in [115]). This crosstalk provides an explanation of how physiological stimuli affect xenoreceptor activities and how xenobiotics/drugs may affect physiological functions through xenoreceptor activation. The involvement of transcription factors in CAR and PXR expression regulation is reviewed in the following section and summarized in Table 1.

\subsection{Hepatic Nuclear Factor $4 \alpha$}

It is acknowledged that HNF4 $\alpha$ represents a central regulator of gene transcription in hepatocytes. Mouse models with specific and conditional deletion of HNF4 $\alpha$ in hepatocytes show that this transcription factor is crucial for liver early embryonic development [116] and also for adult liver function [117].

In $H n f 4 \alpha^{-/-}$mouse fetuses, many genes that are essential for a functional hepatic parenchyma are not expressed, including Pxr [118]. In mice with conditional Hnf4 $\alpha$ deletion, Cyp3a basal expression is reduced in fetal and adult life, and inducible expression of Cyp3a is reduced in adults [119]. Pxr is not expressed in fetal liver of $H n f 4 \alpha^{-/-}$mice, while Car is not detected in fetal liver of wild-type and 
mutant animals. No difference has been observed in Pxr expression in wild-type and $H n f 4 \alpha^{-/-}$adult mice. Conversely, Car expression is significantly lower in the liver of $H n f 4 \alpha^{-/-}$mice than in wild type animals. These results suggest a dichotomy in HNF4 $\alpha$ function in adult and fetal liver [119].

In the human HepG2 cell line, PXR promoter activity is significantly increased by co-expression of HNF4 $\alpha$ through a DR1 element located on the proximal promoter. Moreover, PXR mRNA level positively correlates with that of $H N F 4 \alpha$ in human liver tissue samples [120]. By screening a transcription factor siRNA library in pancreatic cancer cells (AsPC-1) that express high PXR levels, Oladimeji et al. identified N-alpha-acetyltransferase (NAA10) as a factor in the transcriptional machinery that regulates PXR [121]. NAA10 interacts with PXR promoter and co-immunoprecipitates with HNF4 $\alpha$, suggesting that NAA10 and HNF4 $\alpha$ function in a complex to regulate PXR transcription.

HNF $4 \alpha$ locus is transcriptionally regulated through the use of two distinct promoters, P1 and P2, from which six ( $\alpha 1$ to $\alpha 6$ ) and three isoforms ( $\alpha 7$ to $\alpha 9$ ) are generated though alternative splicing of $H N F 4 \alpha$ pre-mRNA (reviewed in [122]). In murine liver, HNF4 $\alpha 7$ is expressed mainly in embryos and is almost absent in adult animals, whereas HNF $4 \alpha 1$ is almost exclusively detected in adults [123]. In most studies on HNF $4 \alpha$ role in gene regulation, the specific function/expression of the different isoforms was not addressed. Only one study described the specific functions of the HNF4 $\alpha 1$ and HNF4 $\alpha 7$ isoforms. During human liver development, $C A R$ mRNA level increases in parallel, and is correlated with $H N F 4 \alpha 1$ level in adults, but not with $H N F 4 \alpha 7$. Moreover, $H N F 4 \alpha 7$ mRNA overexpression in HCC samples is accompanied by a marked decrease in CAR mRNA level. In CV1 cells, HNF4 1 strongly enhances human $C A R$ promoter activity, whereas HNF4 $\alpha 7$ is a poor activator and acts as a repressor of HNF4 $\alpha 1$-mediated transactivation of the CAR promoter [124]. PHH transduction by HNF4 $\alpha 7$-expressing lentiviruses decreases CAR mRNA level [124], while transduction of liver non-parenchymal epithelial cells [125] with HNF4 $\alpha 1$-expressing lentiviruses increases CAR mRNA expression (unpublished results).

HNF4 $\alpha$ is a master regulator of liver gene expression through a complex mechanism that requires its alternative splicing. The balance between the expression of HNF4 $\alpha 1$ and HNF4 47 is probably a key event in the regulated expression of hepatic genes.

\subsection{Glucocorticoid Receptor}

Glucocorticoid receptor (GR) activation by physiological concentrations of glucocorticoids leads to increased expression of CAR and PXR, and also of their partner, RXR. Sub-micromolar concentrations of dexamethasone increase CAR [126], PXR, and RXR $\alpha$ [127] mRNA expression in PHHs. The maximum induction is reached after 6 to $12 \mathrm{~h}$ of exposure to $100 \mathrm{nM}$ dexamethasone, and is greatly diminished by the GR antagonist RU486. Ketoconazole and miconazole, two antifungal drugs, also inhibit CAR and PXR mRNA expression in PHHs through their antagonist activity on GR [128]. Dexamethasone-mediated PXR and CAR induction was confirmed at the protein level $[126,129]$. A functional distal glucocorticoid response element (GRE) has been identified on CAR promoter [130], and putative GREs have been predicted by in silico analysis to be present on PXR proximal promoter [106]. Co-transfection of a GR expression plasmid with a reporter plasmid that harbor $2.2 \mathrm{~kb}$ of the PXR proximal promoter increases promoter activity. Conversely, the promoter activity is reduced when using a $1.5 \mathrm{~kb}$ sequence of the PXR promoter [106]. However, the presence of a functional GRE on PXR promoter has not been demonstrated yet, and an indirect effect of GR cannot be ruled out. Recently, Smutny et al. proposed that dexamethasone downregulates the expression of hsa-miR-18a-5p, resulting in the stabilization of the $3^{\prime}$ UTR of PXR mRNA and its upregulation [131]. Therefore, GR may regulate PXR through a dual mechanism that involves the activation of PXR promoter and the stabilization of PXR 3'UTR via hsa-miR-18a-5p downregulation.

In rat and mouse primary hepatocytes and in the rat hepatoma H4-II-E-C3 cell line, PXR mRNA and protein expression are regulated by GR [129,132-134]. A rat pancreatic acinar-like cell line can be differentiated to HLC by incubation with $10 \mathrm{nM}$ dexamethasone for 14 days [135]. Interestingly, mRNA expression of Pxr; Rxr $\alpha$; and, to a lesser extent, Car is increased following dexamethasone-induced 
differentiation, leading to fully functional receptors [135]. In zebrafish larvae and adult liver exposed to dexamethasone, prednisolone, and triamcinolone, $p x r$ is among the three most upregulated genes [136]. Conversely, in vitro exposure of rainbow trout primary hepatocytes to $1 \mu \mathrm{M}$ dexamethasone for $24 \mathrm{~h}$ significantly reduces $p x r$ mRNA expression [27]. At this concentration, dexamethasone might activate PXR, and this might inhibit PXR expression through a feedback mechanism [131].

GR-mediated PXR regulation is not restricted to liver. Pxr mRNA is detected in mouse lung following dexamethasone treatment (intraperitoneal injection) for 4 days, but not in control mice. The mouse PXR ligand pregnenolone $16 \alpha$-carbonitrile (PCN) cannot trigger consistently the increase of Cyp3a mRNA and protein in the lung of control mice, whereas CYP3A levels are significantly increased in mice treated with dexamethasone and PCN [137]. Pxr mRNA expression is also upregulated in response to dexamethasone in rat jejunum, ileum, and colon tissue sections [138]. Finally, PXR protein expression was found to be increased in brain-blood barrier capillaries of rats treated in vivo with dexamethasone [68] and in in vitro-stimulated brain endothelial cells [139].

The existence of a GR-(PXR/CAR)-drug metabolizing and transporter signal transmission cascade was proposed due to GR role in PXR and CAR gene regulation [115]. Consequently, modification of GR expression or activity may strongly affect PXR and CAR expression.

\subsection{Aryl Hydrocarbon Receptor}

AHR is a basic helix-loop-helix/per-Arnt-Sim transcription factor that can be activated by exogenous and endogenous ligands [140]. Besides its numerous cellular functions, the best characterized AHR function to date is the response to xenobiotics through induction of the DMET network (reviewed in [140]). Several pieces of evidence suggest that AHR also regulates CAR and PXR expression through unknown mechanisms.

In mouse liver and extrahepatic tissues, AHR activation increases Car mRNA expression with a temporal pattern similar to that of Cyp1a1, a known AHR target gene. This induction is further confirmed in PHHs in response to various AHR activators [72]. For instance, benzo[a]pyrene activates Car promoter, induces Car transcription in rat hepatocytes, and enhances the phenobarbital-dependent induction of Cyp2b1 [141]. Conversely, PXR mRNA expression is reduced after incubation of PHHs with the AHR ligand TCDD for $24 \mathrm{~h}$ [142]. This inhibition is reversed by transfection of anti-AHR siRNAs. Moreover, in HepaRG cells and PHHs, AHR activation decreases rifampicin-induced expression of CYP3A4 [142].

\subsection{Farnesoid X Receptor}

Farnesoid X receptor (FXR) is strongly expressed in liver and intestine, and is the master transcriptional regulator of several entero-hepatic metabolic pathways implicated in bile acid, lipid, and glucose homeostasis [143]. Several studies have shown the importance of CAR and PXR in the regulation of bile acid homeostasis [144]. Jung et al. demonstrated that in mice, FXR positively regulates Pxr expression [145], leading to upregulation of PXR target genes. Bile acids activate FXR that then blocks the synthesis and promotes breakdown of bile acids through PXR transcriptional activation. The combination of the two mechanisms leads to efficient liver protection against bile acid-induced toxicity.

\subsection{Thyroid Receptor}

CAR is involved in the metabolism of thyroid hormones (THs), mainly by inducing enzymes involved in their breakdown $[101,146]$. On the other hand, in a rat model of acute stroke induced by middle cerebral artery occlusion, hypothyroidism after ischemia/reperfusion brain injury was found to be correlated positively with nuclear thyroid receptor (TR) and CAR levels. In vitro experiments indicated that incubation with the TH T3 increases CAR cytoplasmic and nuclear expression [147], as described earlier in rat hepatocyte progenitor cells, called small hepatocytes. The exact mechanism of 
CAR regulation by TH is unknown and may be indirect because TR $\alpha$ binding to the TRE-like sequence of CAR promoter has not been observed [148]. Conversely, PXR does not seem to be affected by THs.

Table 1. Transcription factors that regulate CAR and PXR expression.

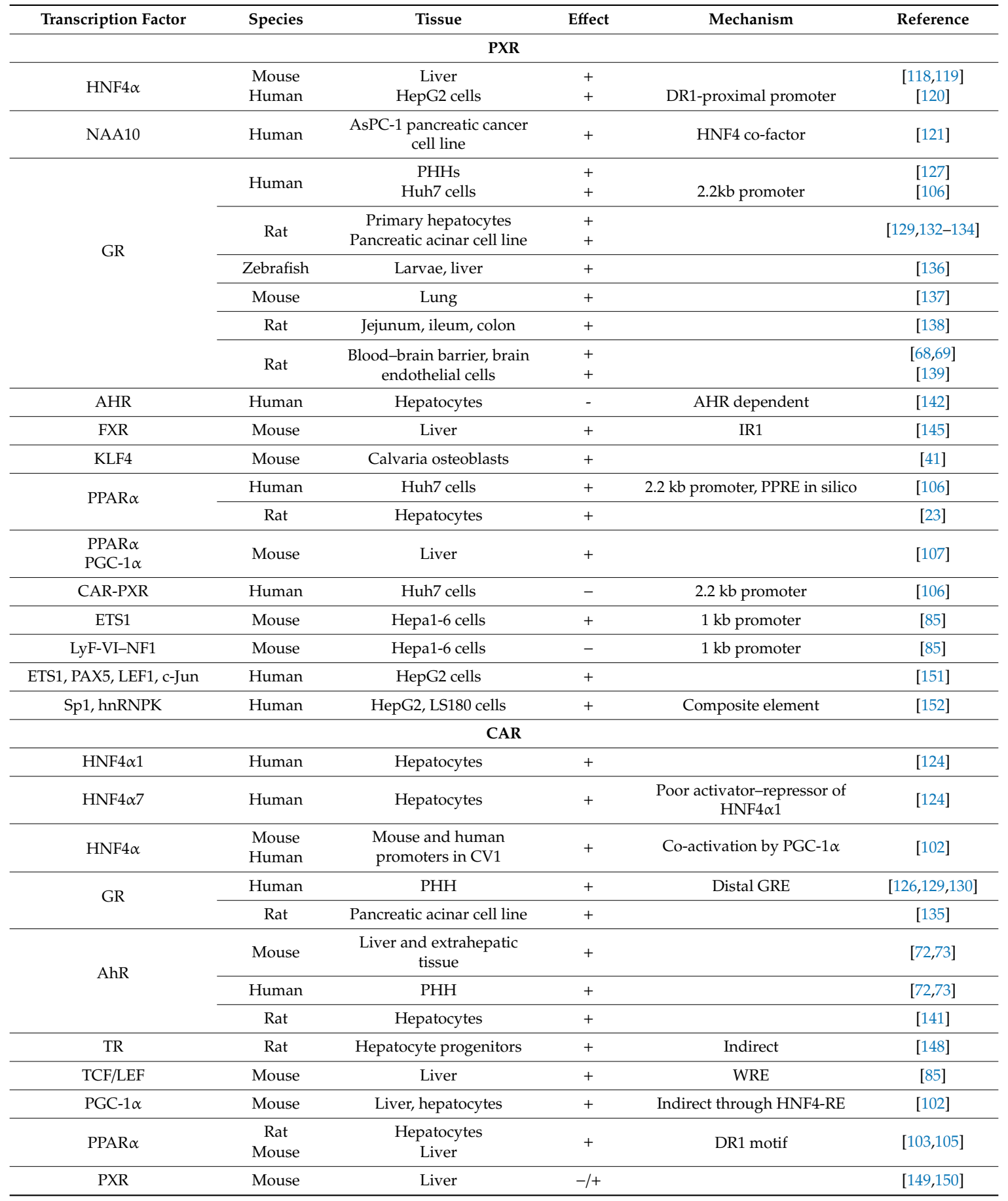

PHH: Primary Human Hepatocytes; PPRE: PPAR Responsive Element; WRE: Wnt Responsive Element.

\subsection{Other Transcription Factors}

PXR participates in osteoblast differentiation and represses osteoblast mineralization. Specifically, Kruppel-like factor 4 inhibits osteoblast differentiation while inducing PXR expression in calvaria osteoblasts [41]. 
Aouabdi et al. demonstrated that estrogen receptor, GR and PPAR $\alpha$ have a positive effect on $P X R$ expression in experiments in which Huh7 hepatoma cells were co-transfected with the $2.2 \mathrm{~kb}$ $P X R$ promoter and expression plasmids for ligand-activated transcription factors. Moreover, CAR and PXR significantly decreased the basal expression of the PXR promoter construct [106]. However, opposite conclusions were reported by studies in mice. Experiments in Pxr and Car single KO mice indicated that PXR represses Car expression, whereas CAR does not reciprocally inhibit Pxr basal expression [149]. Conversely, in the presence of its ligand PCN, PXR self-regulates its expression and upregulates Car expression, whereas CAR ligand has no effect [150]. It is unclear whether the differences in the cross-talk between PXR and CAR are due to the different models used or whether they are species-specific.

Analysis of mouse Pxr distal promoter (5 kb) indicates that the first $1000 \mathrm{bp}$ are sufficient to confer maximal liver-specific expression. The presence of an in silico predicted E26 transformation-specific sequence 1 (ETS1) site was confirmed by EMSA and ChIP experiments. In transient transfection experiments in Hepa 1-6 cells, ETS1 increases mouse Pxr promoter activation by 1.6-fold. Conversely, proteins of the Ikarose family and nuclear factor family (LyF-VI and NF-1) behave as repressors of the mouse Pxr promoter activity [85].

Transfection of human PXR proximal promoter deletion variants in HepG2 cells allowed for identifying putative activation elements in the -497 and -397 and negative regulatory elements in the -397 to -315 regions [151]. Transcription factors from the Ets family (PU.1 and ETS1), together with PAX5, LEF-1, and c-Jun, lead to the coordinated upregulation of $P X R$ gene transcription. The same group identified a composite element (CE) of multiple overlapping cis-elements in PXR proximal promoter (from -449 to -427) that is involved in the transcriptional regulation of PXR basal expression, both in HepG2 and intestinal LS180 cells [152]. DNA-protein interaction studies showed that three binding complexes interact with $\mathrm{CE}$ and contain at least Sp1 and heterogeneous nuclear ribonucleoprotein $\mathrm{K}$ (hnRNPK) [152].

\section{Epigenetic and Post-Transcriptional Regulations}

Several studies have demonstrated the fact that epigenetic modifications affect $C A R$ and PXR gene expression through different mechanisms (DNA methylation, histone modifications, and non-coding RNAs).

\subsection{Histone Modifications}

Active gene transcription is associated with chromatin structure relaxation following histone tail acetylation that allows wider accessibility to DNA-binding proteins. Conversely, histone hypoacetylation is associated with reduced gene transcription.

Histone 4 (H4) acetylation at the proximal human CAR promoter region is promoted by the GR agonist dexamethasone, and inhibited by lipopolysaccharide (LPS) and interleukin-1 $\beta$ (IL-1 $\beta$ ) [153]. This suggests that pro-inflammatory signaling affects the chromatin structure close to the $C A R$ promoter and consequently $C A R$ transcription.

SWI/SNF is an ATP-dependent chromatin remodeling complex that regulates gene transcription, being is composed of two catalytic ATPases and additional subunits named BRG/BM-associated factors (BAFs). Meng et al. demonstrated that the SWI/SNF complex is recruited via BAF60a to the Car promoter in a diet-sensitive manner in mice [154], leading to increased histone $\mathrm{H} 3$ acetylation and trimethylation of $\mathrm{H} 3$ lysine $4(\mathrm{H} 3 \mathrm{~K} 4 \mathrm{~m} 3)$ on the Car promoter and increased Car expression [154]. Mice in which Baf60a was ablated are resistant to diet-induced atherosclerosis [154]. Indeed, hepatic Baf60a deficiency impairs bile acid metabolism and intestinal cholesterol absorption through downregulation of Car and of genes involved in the expression of the alternative bile acid pathway [154]. 


\subsection{DNA Methylation}

When occurring at a gene promoter, DNA methylation typically represses gene transcription. In human pancreatic cancer cells, CAR was identified among the methylated genes [155]. In HepG2 cells, berberine, an isoquinoline alkaloid, inhibits expression of CAR and of its target genes CYP2B6 and CYP3A4 [156]. Berberine enhances DNA methylation level genome-wide, but reduces it at CpG sites of the CYP2B6 and CYP3A4 gene promoters in HepG2 cells that stably express CAR [156]. CAR promoter methylation was not described [156].

PXR activity is epigenetically regulated by chromatin modifications, DNA methylation, and non-coding RNAs (reviewed in [157]). Little is known about the epigenetic regulation of its expression. In human neuroblastoma cell lines, a CpG island located around exon 3 of PXR shows promoter activity, and its methylation status is inversely correlated with PXR expression [158]. Habano et al. demonstrated that in colon cancer cell lines, DNA methylation of the CpG-rich sequence of the PXR promoter is increased in cell lines with low PXR expression [159]. Moreover, lower PXR promoter methylation level was observed in colorectal cancer tissues compared with adjacent normal mucosa, suggesting PXR mRNA upregulation during carcinogenesis [159].

Epigenetic alterations may induce persistent phenotypic changes. For instance, analysis of the DNA methylation status of CpG-enriched sites of the PXR promoter in white blood peripheral cells from pregnant women showed hypermethylation during healthy pregnancy and lower methylation in women with intrahepatic cholestasis of pregnancy [160]. This profile was correlated with bile acid profiling, particularly conjugated bile acids [160].

\section{3. microRNAs (miRNAs)}

PXR protein level is not correlated with PXR mRNA expression in human liver, indicating the involvement of post-transcriptional regulation [161]. Among the molecular mechanisms of post-transcriptional regulation, miRNAs are important regulators of target genes by binding to complementary regions of transcripts to repress their translation or regulate their degradation. The data available on CAR and PXR regulation by miRNAs are summarized in Table 2.

Table 2. miRNAs that regulate CAR and PXR expression.

\begin{tabular}{|c|c|c|c|c|}
\hline miRNA & Cell Type/Species & Target & Effects & Reference \\
\hline \multirow{6}{*}{ miRNA-148a } & HepG2, LS180 cells & $\begin{array}{c}\text { PXR } \\
3^{\prime}-\mathrm{UTR}\end{array}$ & Inhibition & [161] \\
\hline & Human liver & PXR & $\begin{array}{l}\text { No correlation in the Chinese Han } \\
\text { population }\end{array}$ & [164] \\
\hline & Human liver & $\begin{array}{l}\text { PXR } \\
\text { CAR }\end{array}$ & No correlation & [163] \\
\hline & Human liver & $\begin{array}{l}\text { PXR } \\
\text { CAR }\end{array}$ & Positive correlation & [162] \\
\hline & LO2 liver cells & PXR & Inhibition & {$[167]$} \\
\hline & Oropharyngeal cancer cell lines & PXR & Inhibition & [168] \\
\hline \multirow{3}{*}{$\mathrm{miR}-34 \mathrm{a}$} & $\begin{array}{l}\text { Hela, HepG2 cells } \\
\text { Human hepatocytes }\end{array}$ & PXR & Inhibition through HNF4- $\alpha$ & [165] \\
\hline & Human liver & $\begin{array}{l}\text { PXR } \\
\text { CAR }\end{array}$ & Negative correlation & [162] \\
\hline & Human liver & CAR & Negative correlation & {$[163]$} \\
\hline miR449-a & $\begin{array}{l}\text { Hela, HepG2 cells } \\
\text { Human hepatocytes }\end{array}$ & PXR & Inhibition through HNF4- $\alpha$ & [165] \\
\hline miR-204 & Human liver & CAR & Positive correlation & [163] \\
\hline miR-21 & Human liver & CAR & Negative correlation & {$[163]$} \\
\hline mir-150 & Human liver & $\begin{array}{l}\text { PXR } \\
\text { CAR }\end{array}$ & Negative correlation & [162] \\
\hline
\end{tabular}


Table 2. Cont.

\begin{tabular}{|c|c|c|c|c|}
\hline miRNA & Cell Type/Species & Target & Effects & Reference \\
\hline miR27a & Human liver & PXR & Negative correlation & [162] \\
\hline miR-561 & HepG2 & $\begin{array}{l}\text { PXR } \\
\text { CAR }\end{array}$ & Induction through DAX-1 inhibition & [169] \\
\hline \multirow[b]{2}{*}{ miR-137 } & Mouse primary hepatocytes & PXR & Inhibition & [9] \\
\hline & $\begin{array}{l}\text { Neuroblastoma, } \\
\text { HCC, and CRC }\end{array}$ & CAR & Inhibition & [170] \\
\hline miRNA-30c-1-3p & 293T, HepG2, LS180 cells & $\begin{array}{c}\text { PXR } \\
3^{\prime} \text {-UTR }\end{array}$ & Inhibition & [171] \\
\hline miR-140-3p & $\begin{array}{l}\text { HepG2 cells } \\
\text { MHCC } 97-H \text { cells }\end{array}$ & $\begin{array}{c}\text { PXR } \\
3^{\prime} \text {-UTR }\end{array}$ & Inhibition & [172] \\
\hline \multirow[b]{2}{*}{ miRNA-18a-5p } & LS180 cells & PXR & Inhibition & [166] \\
\hline & $\begin{array}{c}\text { Human hepatocytes } \\
\text { Mouse liver } \\
\text { HepG2 cells }\end{array}$ & $\begin{array}{c}\text { PXR } \\
3^{\prime} \text {-UTR }\end{array}$ & Inhibition & [131] \\
\hline $\operatorname{miR}-211-5 p$ & HepG2.2.15 cells & CAR & $\begin{array}{l}\text { Inhibition through sequestration by } \\
\text { the lncRNA F11-AS1 }\end{array}$ & [173] \\
\hline miR-486-5p & HepaRG human hepatocytes & PXR & $\begin{array}{c}\text { Inhibition through sequestration by } \\
\text { the lncRNA LINC00844 }\end{array}$ & [174] \\
\hline
\end{tabular}

miRNA-148a is the first and most studied miRNA implicated in xenoreceptor regulation. It negatively regulates PXR gene expression in human liver, intestinal, and oropharyngeal cell lines. Some studies reported a positive correlation of miRNA-148a expression with that of $C A R$ and PXR in human liver tissues [162], but not others [163,164].

$C A R$ and PXR mRNA levels are negatively correlated with that of miRNA-34a in human liver tissues, and PXR expression is indirectly inhibited by miRNA-34a through inhibition of HNF4 $\alpha$ expression [165].

The expression of PXR and CYP3A is inhibited by miRNA-18a-5p. In human and mouse liver cells, Smutny et al. observed a significant upregulation of miRNA-18a-5p expression following $6 \mathrm{~h}$ of incubation with the PXR ligands rifampicin and PCN, suggesting a negative feedback regulation in hepatic cells [131]. In contrast, Sharma et al. reported that miRNA-18a-5p is inhibited in LS180 colon adenocarcinoma cells incubated with rifampicin for $6 \mathrm{~h} \mathrm{[166].} \mathrm{These} \mathrm{results} \mathrm{highlight} \mathrm{the} \mathrm{tissue-specific}$ regulation and the importance of temporal profiling.

\subsection{Long Non-Coding RNAs (lncRNAs)}

In HepG2.2.15 cells that stably express hepatitis B virus (HBV), the HBx protein inhibits the expression of the IncRNA F11-AS1 and induces that of CAR mRNA [173]. The lncRNA F11-AS1 binds to miR-211-5p, weakening its ability to bind to CAR and inhibit its expression [173]. Emerging evidence has demonstrated that lncRNAs can function as competing endogenous RNAs (ceRNAs) for specific miRNAs, regulating their function and downstream targets [175]. For instance, LINC00844 acts as a ceRNA for miR-785-5p and regulates PXR and DMET expression in HepaRG cells and PHHs [174].

A lncRNA microarray analysis of human liver samples showed that expression of the lncRNA hepatocyte nuclear factor 1 alpha antisense 1 (HNF1 $\alpha$-AS1), an antisense RNA of HNF1 $\alpha$, was correlated with the mRNA expression of several CYPs and also PXR and CAR [176]. Alteration of HNF1 $\alpha$-AS1 expression in human Huh7 liver cells by siRNA-mediated knockdown or plasmid overexpression results in significant changes of PXR mRNA expression, without any concomitant change of CAR and HNF1 $\alpha$ expression [176].

\subsection{RNA Editing}

The adenosine deaminase acting on RNA (ADAR) enzymes catalyze adenosine-to-inosine RNA editing that modulates gene expression and function. Transfection of siRNAs against ADAR1 but not $A D A R 2$ in HepG2 cells resulted in a significant increase in CAR mRNA and protein expression, as well 
as in CYP3A4 and CYP2B6 induction [177]. Incubation with the transcriptional inhibitor $\alpha$-amanitin led to an increase of $C A R$ mRNA half-life from $6.6 \mathrm{~h}$ to $18.6 \mathrm{~h}$ following ADAR1 silencing, demonstrating that ADRA1 inhibition increases CAR mRNA stability in a post-transcriptional manner [177]. Moreover, ADAR1 attenuates CAR splicing at intron 3 in an RNA editing-independent manner, possibly resulting in $C A R$ downregulation.

\section{Post-Translational Regulation}

Masuyama et al. first showed that PXR is degraded by the proteasome system. Indeed, selective inhibitors of the proteasome pathway, including MG-132 and $\beta$-lactone, increase the steady state levels of native PXR protein in mouse mammary gland (BALB-MC) cells [178]. PXR degradation depends on its interaction with suppressor for gal 1 (SUG1, a component of the $26 \mathrm{~S}$ proteasome complex), and is blocked by endocrine-disrupting chemicals. In the presence of cycloheximide, constitutive PXR is rapidly degraded $(\mathrm{t} 1 / 2,<4 \mathrm{~h})$, whereas the degradation of progesterone-occupied PXR proceeds at a slower rate $(\mathrm{t} 1 / 2,<8 \mathrm{~h})[178]$.

Later, it was shown that RBCK1, an E3 ubiquitin ligase, interacts with human PXR to increase its ubiquitination and to decrease its expression in PHHs and other cell lines [179]. Ong et al., by using mass spectroscopy and a kinome-wide siRNA screen, identified a pathway that regulates human PXR stability via phosphorylation-facilitated ubiquitination by the serine/threonine kinase DYRK2 and the E3 ubiquitin ligase UBR5 [180]. PXR might be a substrate for multiple E3 ligases, as previously described for other proteins.

Human PXR can also be degraded via an increase of calpain activity, adding a new level of complexity to its turnover [181]. Specifically, in LS180 cells pretreated with cycloheximide, PXR half-life was of $\approx 4 \mathrm{~h}$, close to the value observed in the mouse, and its degradation was inhibited by incubation with a selective calpain inhibitor. However, in contrast to what observed in the mouse, the presence of a PXR agonist (rifampicin) did not significantly affect PXR turnover rate.

Human CAR activity is regulated by the proteasome complex at multiple levels. CAR is ubiquitinated, and proteasomal inhibition leads to intracellular accumulation of ubiquitinated CAR [182]. However, despite its accumulation, CAR transcriptional activity is markedly downregulated [182]. Indeed, in PHHs, proteasomal inhibition enhances the interaction between CAR and HSP90, affecting its nuclear translocation. This demonstrates that the proteasome system plays a critical role in modulating CAR cellular trafficking [182]. Moreover, mammalian two-hybrid screening experiments showed that MG-132 (a proteasome inhibitor) inhibits the interaction between CAR1 and the co-activators SRC1 and GRP1. Finally, as shown for PXR, SUG-1 represses both constitutive and ligand-activated transcriptional activity of CAR1 [182]. The proteasome ability to regulate CAR activity at multiple levels may contribute to fine-tuning CAR-mediated activation of target genes in response to different CAR ligands and indirect activators, such as phenobarbital.

\section{Pathologies}

\subsection{Inflammation}

Inflammation is a protective response to life-threatening insults (e.g., infection and injury). However, long-term dysregulation of inflammatory pathways contributes to many chronic diseases, including cancer, cardiovascular disease, diabetes, obesity, osteoporosis, rheumatoid arthritis, inflammatory bowel disease, asthma, and central nervous system diseases.

Inflammation and infection affect the activity and expression of DMETs regulated by xenoreceptors. Indeed, during infection or systemic inflammation, liver, due to its strategic position in the body, integrates signals that affect the drug pharmacokinetics and bioavailability. Since 2000, significant advances have been made in unraveling the molecular mechanism that controls the intricacies of inflammation and xenoreceptor-regulated processes. The cross-talk between nuclear receptors 
and drug metabolism enzymes has been described elsewhere [183], and this review focuses on inflammation-mediated regulation of CAR and PXR expression.

\subsubsection{Liver}

Induction of acute phase response by administration of LPS or pro-inflammatory cytokines is characterized by the suppression of DMET expression and activity in liver. This effect is associated with a marked reduction of mouse Car and Pxr mRNA levels, following intraperitoneal injection of LPS [184]. Administration of PHA40, an inhibitor of nuclear factor $\mathrm{KB}$ (NF- $\mathrm{KB}$ ), with LPS does not significantly alter the endotoxin-mediated downregulation of Car mRNA. This suggests that NF- $\mathrm{kB}$ does not play a primary role in CAR regulation after endotoxin exposure. Conversely, LPS-mediated inhibition of PXR mRNA and protein expression is significantly attenuated by PHA408. Surprisingly, LPS-mediated Car mRNA inhibition is abolished in $\mathrm{Pxr}^{-/-}$mice, suggesting a role of PXR in endotoxin-mediated Car inhibition [185]. In mouse Kupffer cells, LPS-mediated Pxr downregulation is reversed by incubation with selective toxicants [186], antioxidants [186-188], and inhibitors of xanthine oxidase and NADPH oxidase [186], suggesting that liver resident macrophages, reactive oxygen species, and xanthine and NADPH oxidases may be involved in this process. On the other hand, selective inhibitors of inducible nitric oxide synthase have no effect [185]. Pxr and Car mRNAs are also downregulated in response to lipoteichoic acid (LTA) from Gram-positive bacteria, a Toll-like receptor 2 (TLR2) ligand, the signaling of which is mediated through Toll-interleukin 1 receptor domain-containing adaptor protein (TIRAP). Nuclear receptor level is reduced in LTA-treated $T l 2^{+/+}$and Tirap ${ }^{+/+}$mice, but not in $\mathrm{Tlr}^{-/-}$and Tirap ${ }^{-/-}$mice, demonstrating that TLR2 effect on nuclear receptor expression is mediated by TIRAP [189].

IL-1 $\beta$, IL- 6 , and TNF- $\alpha$ are considered the major pro-inflammatory cytokines, with their role in the regulation of CAR and PXR expression having been thoroughly investigated. CAR and PXR mRNA downregulation in PHHs in response to IL-6 exposure was first described by Pascussi et al. in 2000 [190]. Dose-dependent inhibition was also observed in HepG2 cells (mRNA and protein levels) [191] and in HepaRG cells (mRNA level) [192]. A recent study identified differentiated embryonic chondrocyte-expressed gene 1 (DEC1) as a mediator of IL-6-mediated downregulation of PXR and CAR in PHHs and HepG2 cells [193]. DEC1 expression is induced in response to IL-6, and DEC1 overexpression has a similar effect as IL-6 on CAR and PXR expression. DEC1 knockdown reverses $C A R$ and PXR downregulation by IL-6. Moreover, DEC1 interacts with RXR $\alpha$, and IL-6 enhances this interaction. IL-6 inhibitory effect on $C A R$ and $P X R$ expression is also observed in mouse liver [194]. Fasting-mediated increase of Car and Pxr mRNA level in mouse liver is significantly reduced by short-term ( $1 \mathrm{~h}$ ) exposure to IL-6 [195]. Surprisingly, the mRNA expression of CAR and PXR is increased in response to high IL-6 concentration in primary porcine hepatocytes [196]. Incubation with IL- $1 \beta$ also significantly reduces $C A R$ mRNA expression in PHHs by activation of the p65 subunit of NF- $\mathrm{kB}$ that interferes with the distal glucocorticoid response element located on CAR promoter [153]. In contrast, PXR mRNA and protein expression are not affected in liver of IL-1 $\beta$ or TNF- $\alpha$ treated mice, while only Car mRNA is transiently reduced following exposure to these cytokines [197].

\subsubsection{Intestine}

In human colon biopsies from patients with Crohn's disease and ulcerative colitis with active inflammation, the mRNA expression of $C A R$ and its target $A B C B 1$ is reduced compared with samples from healthy controls [29]. PXR expression also is reduced in colon colitis, and is unaffected [198] or reduced [199] in patients with Crohn's disease. PXR expression is not affected in mesenteric adipose tissue from patients with Crohn's disease compared with controls [40]. A strict inverse correlation is observed between colon epithelial PXR expression and NF-KB and IL-8 level in colon biopsies from patients with Crohn's disease [200]. Addition of TNF $\alpha$ to CaCo-2 cell monolayers results in reduced PXR expression and induction of IL-8, suggesting that TNF $\alpha$-mediated PXR expression inhibition occurs through the NF- $\mathrm{kB}$ pathway [199]. In mice with ulcerative colitis, CAR and PXR protein 
expression levels in liver are reduced [201,202]. Similarly, CAR protein expression is significantly reduced in colon and ileal crypts of mice with dodecyl sulfate-induced colitis [29]. Pxr expression is downregulated in the intestine of mice treated with LPS [203] and in transgenic mice that constitutively express TNF $\alpha$ [199]. LPS also reduces PXR expression in mouse placenta, and this effect is reversed by antioxidants [204].

It is now well established that the expression of CAR and PXR is regulated negatively during inflammation. In turn, PXR can negatively regulate inflammatory signaling through its ability to inhibit NF- $\mathrm{kB}$ activity. Moreover, interaction of the p65 subunit of NF- $\mathrm{kB}$ with the dimerization partner $R X R \alpha$ reduces PXR transactivation activity (reviewed in [113]).

\subsection{Chronic Diseases}

\subsubsection{Diabetes and Obesity}

Several studies have investigated the expression of drug metabolizing enzymes (DME) and their related nuclear receptors in animals with type 2 diabetes-like syndrome induced genetically or by HFD (Table 3). Contradictory results have been reported, possibly related to differences in the methodologies and animal models used. The level of nuclear receptors, such as CAR, RXR $\alpha$, and $H N F 4 \alpha$, and also of CYP2B and CYP4A, was found to be increased in liver of genetically diabetic $\mathrm{db} / \mathrm{db}$ mice compared with control C57BL/6 mice [205], and Pxr was found to be upregulated in kidney [206]. However, Lam et al. did not observe Car and Pxr deregulation in liver in the same model [207]. Moreover, the opposite was observed in Zucker fatty rats [208], suggesting that the altered energy metabolism in these animals is not the only cause of CAR changes, or that the position of the mutations in the leptin receptor gene in these two models is important. In male rats with diet-induced obesity (HFD for 12 weeks), the mRNA expression of Car and Ppar $\gamma$ was increased in the liver compared with rats in the low fat diet group, without significant differences in Pxr, Rxr $\alpha$, and Ppar $\alpha$ expression level [209]. On the other hand, a significant increase in the expression of Pxr, Fxr, and Lxrs and their target genes, but not Car, was observed in female Sprague-Dawley rats fed an HFD diet for 13 weeks that were mildly obese or overweight [210].

In adult male mice fed a HFD, Car and Ppara were significantly upregulated during the development of insulin resistance and diabetes, while Pxr and Hnf $4 \alpha$ levels were increased only in the group on HFD for 4 weeks (versus 8 and 18 weeks) [211], as observed in HFD male rats [212]. In another study, Car and its target gene Cyp $2 b 10$ were significantly upregulated at 12 weeks, whereas Pxr exhibited a moderate but significant increase at 16, 24, and 32 weeks of HFD [213]. In contrast, reduced Car and Pxr levels and decreased DME expression were observed in male CD1 mice fed a HFD, probably due to a cross-talk between these nuclear receptors and the associated inflammation [214]. In male Tsumura Suzuki obese diabetes (TSOD) mice (a polygenic model that gradually develops obesity and type 2 diabetes), the mRNA expression of Pxr and Pgc-1 $\alpha$, but not of Car, was increased compared with control mice, resulting in increased CYP3A expression and activity. Autoregulation by PGC- $1 \alpha$-activated PXR was proposed as a mechanism for higher Pxr expression [215]. To note, Car expression was increased in male and female mice fed a HFD for 11 and 36 weeks post-weaning, respectively [216]. Female mice are resistant to the HFD effects [211], suggesting a sexual dimorphic response that could be related to the well documented sexual dimorphism of DME and nuclear receptor basal expression [20,21]. The intestinal and renal expression of Pxr also is affected by obesity and diabetes. PXR mRNA and protein levels were significantly increased in duodenum and jejunum, but not ileum, in a rat model of type 2 diabetic mellitus (HFD and streptozotocin treatment) [217]. Gut microbiota metabolites, such as the secondary bile acid lithocholic acid that activates PXR and is elevated in the presence of type 2 diabetic mellitus, could be involved in this upregulation [217]. In normal mouse kidney, Pxr is selectively expressed in proximal tubular cells and the promoter is demethylated. In db/db mice, Pxr mRNA level is significantly increased, and in the promoter, DNA methylation is further reduced and activation histone marks are enriched. This indicates that in 
diabetic kidney, $P x r$ is upregulated through alteration of epigenetic regulations [218]. Information on PXR/CAR expression in patients with diabetes and obesity are scarce. A significant upregulation of PXR has been observed in patients with chronic kidney disease, including diabetic kidney disease, but also in patients with acute renal dysfunction without rejection after transplantation, suggesting a possible role of PXR in human renal injury [218].

Hyperglycemia and hyperinsulinemia in type 2 diabetes mellitus have been linked to NAFLD that can progress to inflammation, fibrosis/cirrhosis, and HCC [219]. High glucose concentration increases PXR expression and activity in HepG2 cells. The AMPK pathway appears to be important for regulating the glucose-induced PXR activity, but does not affect the glucose-dependent regulation of PXR expression [220]. High glucose concentration appears to modulate LPS and IL-6 effect on PXR expression and subcellular localization in hepatocytes [221]. Conversely, long-term exposure of PHHs to hypoglycemic conditions results in increased expression of PXR, CAR, and their target genes [222], in line with data obtained during fasting in rodents [107]. One study investigated in mouse hepatocytes and human hepatic cells the insulin induced-downregulation of carboxylesterase (CES), a PXR target gene, in order to better understand drug-drug interactions and to guide the rational use of drugs in patients with type 2 diabetes. This effect involves the suppression of PXR mRNA and protein expression by insulin in a PI3K/Akt-dependent manner [223]. Interestingly, CES expression variations are associated with PXR expression and activation. Metformin and imitamib both suppress CES through PXR downregulation, but the underlying mechanisms require additional studies [224,225]. In cultured human retinal pigment epithelium cells, high glucose induces iNOS expression that in turn partly suppresses PXR transcription, thus inhibiting the expression and activity of P-glycoprotein. Additional studies are needed to determine the functional implication of this crosstalk in the human outer blood-retinal barrier impairment and diabetic retinopathy progression [226].

\subsubsection{Fibrosis and Cirrhosis}

Worsening of chronic liver disorders, such as chronic HBV and hepatitis $\mathrm{C}$ virus (HCV) infection and alcohol abuse, leads to alcohol liver disease (ALD), NASH [227], and chronic cholestatic disease [228] (primary sclerosis cholangitis-PSC, and primary biliary cirrhosis-PBC). These disorders are characterized by hepatocyte damage, recruitment of inflammatory cells, and activation of collagen-producing cells. Data are summarized in Table 3.

In liver specimens from patients with end-stage liver disease (ALD, HCV, and PSC), the expression of CAR, RXR, and AHR, and to a lesser extent PXR, was decreased in comparison with controls, regardless of the pathology, and thus may be one of the factors associated with the reduced liver metabolic capacity and hepatic failure [229]. In patients with chronic HCV infection, the expression of CAR and PXR is largely correlated with the fibrosis stage and the level of metabolic enzymes [230]. The expression of CAR and PXR is lowest in liver of patients with stage 3 liver fibrosis [231]. CAR levels are unchanged in steatotic, alcoholic, and diabetic cirrhotic liver specimens, while PXR expression is reduced only in liver of patients with cirrhosis and diabetes [232]. Differential expression of specific nuclear receptors correlated with the histologic severity of specific NAFLD features, particularly fibrosis, in pediatric patients enrolled in the TONIC clinical trial. Specifically, $33 \%$ of these nuclear receptors, including CAR, PXR, GCNF, COUP-TF1, NURR1, PPARs, ERs, RAR/RXRs, and TRs, were upregulated in samples with fibrosis compared with samples without [233]. As fibrosis, regardless of the diagnosis of NASH, is the only histologic feature that exhibits long-term prognostic relevance in adult patients with NAFLD [234], therapeutic modulation of the expression of these receptors may have important clinical implications [233].

In animal models with CCL4-induced cirrhosis, $P x r$ mRNA expression is reduced in rat liver [235] and mouse liver and small intestine [236]. In these rats, combined treatment with insulin-like growth factor-I and interferon- $\alpha$ can increase Pxr expression by improving liver functions and reducing fibrosis [235]. Ginkgolide-A, a natural PXR ligand, improves Pxr expression in liver and intestine of cirrhotic mice [236,237]. Pxr mRNA expression is also reduced in rats with 
thioacetamide-induced liver injury [238]. Stroke-prone spontaneously hypertensive rats (SHRSP5/Dmcr strain) fed a high-fat-cholesterol (HFC) diet develop fibrotic steatohepatitis [239] and show reduced Car and Pxr mRNA expression levels in liver after 8 weeks of this diet [239]. However, CAR and PXR mRNA and protein levels were strongly decreased in HFC-fed males, while they were only slightly affected in HFC-diet fed females [240].

CAR is upregulated in skin and skin fibroblasts isolated from patients with systemic sclerosis. TGF- $\beta$ induces CAR mRNA and protein expression in fibroblasts from healthy donors in a SMAD-dependent manner. Moreover, CAR agonists increase the activation of canonical TGF- $\beta$ signaling and exacerbate the fibrosis phenotype [241].

\subsubsection{Cholestasis}

Recently, Wunsch et al. analyzed PXR expression in two chronic cholestatic conditions: PBC and PSC [242]. They found that PXR expression (mRNA and protein) was strongly increased in both pathologies, but this induction did not correlate with cholestasis biochemical features [242]. A previous study found that the expression of PXR and CAR was reduced to $40-60 \%$ in PBC grade III and IV, but this change was not significant [243]. In patients with obstructive cholestasis, PXR and RXR mRNA and protein, as well as CAR protein levels, were markedly increased in comparison with controls [244,245]. PXR but not CAR mRNA expression was found to be reduced in children with late-stage (but not early stage) obstructive cholestasis caused by biliary atresia [246]. Moreover, after surgical intervention, the expression levels of CAR and PXR were lower in patients with poor prognosis [246]. The anticholestatic activity of bezafibrate was investigated in patients with PBC who showed incomplete response to ursodeoxycholic acid [247]. This study found that bezafibrate is a dual PPAR/PXR agonist with potent anticholestatic activity [247]. It also significantly increases PXR mRNA expression, probably through PPAR $\alpha$ activation. Upregulation of PXR expression and activity may contribute to bezafibrate anticholestatic activity [247].

Table 3. Effect of different pathologies on the expression of nuclear receptors and cytochrome P450 enzyme (CYP) target genes.

\begin{tabular}{|c|c|c|c|c|c|c|}
\hline Species & Model & $\mathrm{s}$ & $\begin{array}{c}\text { Age/ } \\
\text { Treatment }\end{array}$ & Organ & $\begin{array}{c}\text { Nuclear Receptors and CYP Target } \\
\text { Genes }\end{array}$ & REF \\
\hline \multicolumn{7}{|c|}{ Diabetes/Obesity } \\
\hline \multirow{6}{*}{ Mouse } & $\mathrm{db} / \mathrm{db}$ & M & $>10 \mathrm{w}$ & liver & $\begin{array}{l}\text { (+) Car, Rxr } \alpha, \text { Hnf } 4 \alpha, \text { Cyp2b10, Cyp2c29, } \\
\text { Cyp4a10, CAR, PXR, RXR } \alpha, \text { HNF4 } \alpha \\
\alpha, \text { CYP2B10, CYP2C29, CYP4A10 }\end{array}$ & [205] \\
\hline & \multirow{2}{*}{$\mathrm{db} / \mathrm{db}$} & \multirow{2}{*}{ M } & $22 \mathrm{w}$ & \multirow{2}{*}{ kidney } & (-) Pxr & [206] \\
\hline & & & $8 \mathrm{w}$ & & (-) Pxr & [218] \\
\hline & \multirow[t]{2}{*}{$\mathrm{db} / \mathrm{db}$} & \multirow[t]{2}{*}{ M } & $10 \mathrm{w}$ & \multirow[t]{2}{*}{ liver } & $\begin{array}{l}\text { (+) Cyp2b10, Cyp4a10, Cyp2c29 } \\
\text { (0) Car, Pxr, Cyp3a11 }\end{array}$ & \multirow[t]{2}{*}{ [207] } \\
\hline & & & $25 w$ & & $\begin{array}{c}\text { (+) Cyp4a10 (-) Cyp2c29 } \\
\text { (0) Car, Pxr, Cyp3a11, Cyp2b10 }\end{array}$ & \\
\hline & TSOD & M & $\begin{array}{l}12 \mathrm{w} \\
28 \mathrm{w}\end{array}$ & liver & $\begin{array}{c}\text { (+) Cyp3a11 } \\
\text { (+) Pxr, Hnf4 } \alpha, P g c-1 \alpha, \text { Cyp3a11, } \\
\text { CYP3A, CYP2C (0) Car }\end{array}$ & [215] \\
\hline \multirow{5}{*}{ Rat } & Zucker & & $7-9 w$ & liver & $\begin{array}{c}\text { (-) Car, CAR } \\
\text { (0) Rxra, Ppara, Fxr, Lxr }\end{array}$ & [208] \\
\hline & HFD/streptozotocin & & $8 w / 5 w$ & intestine & $\begin{array}{c}\text { (+) Pxr, PXR, Cyp } 3 a 2 \\
\text { (-) Cyp } 2 c\end{array}$ & [217] \\
\hline & HFD & M & $4 \mathrm{w} / 4 \mathrm{w}$ & liver & $(+) P x r$ & [212] \\
\hline & HFD & M & $5 \mathrm{w} / 12 \mathrm{w}$ & liver & $\begin{array}{c}\text { (+) Car, Ppar } \\
\text { (0) PXR, RXR } \alpha, \text { PPAR } \alpha\end{array}$ & [209] \\
\hline & HFD & $\mathrm{F}$ & $6 \mathrm{w} / 13 \mathrm{w}$ & liver & $\begin{array}{c}\text { (+) Pxr, Fxr, Lxrs, Cyp3a2, CYP3A2 } \\
\text { (0) CAR }\end{array}$ & [210] \\
\hline
\end{tabular}


Table 3. Cont.

\begin{tabular}{|c|c|c|c|c|c|c|}
\hline Species & Model & $\mathbf{S}$ & $\begin{array}{c}\text { Age/ } \\
\text { Treatment }\end{array}$ & Organ & $\begin{array}{c}\text { Nuclear Receptors and CYP Target } \\
\text { Genes }\end{array}$ & REF \\
\hline \multirow{7}{*}{ Mouse } & \multirow[t]{2}{*}{ HFD } & M & $\begin{array}{c}5 \mathrm{w} / 4 \mathrm{w} \\
5 \mathrm{w} / 8,18 \mathrm{w} \\
\end{array}$ & \multirow[t]{2}{*}{ liver } & 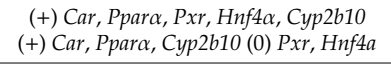 & \multirow[t]{2}{*}{ [211] } \\
\hline & & $\mathrm{F}$ & $\begin{array}{c}5 \mathrm{w} / 4,18 \mathrm{w} \\
5 \mathrm{w} / 8 \mathrm{w}\end{array}$ & & 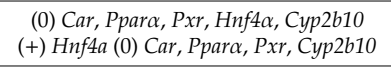 & \\
\hline & HFD & $\begin{array}{c}\mathrm{M} \\
\mathrm{F}\end{array}$ & $\begin{array}{l}4 \mathrm{w} / 11 \mathrm{w} \\
4 \mathrm{w} / 36 \mathrm{w}\end{array}$ & liver & $\begin{array}{l}(+) \text { CAR } \\
(+) \text { CAR } \\
\end{array}$ & [216] \\
\hline & \multirow{3}{*}{ HFD } & \multirow{3}{*}{ M } & $6 \mathrm{w} / 4 \mathrm{w}$ & \multirow{3}{*}{ liver } & (+) Fxr, Cyp3a11 (0) Car, Pxr, Cyp2b10 & \multirow{3}{*}{ [213] } \\
\hline & & & $6 \mathrm{w} / 12 \mathrm{w}$ & & (+) Car, Pxr, Cyp2b10, Cyp3a11 & \\
\hline & & & $6 \mathrm{w} / 16,24,32 \mathrm{w}$ & & (+) Pxr, Cyp3a11 (0) Car, Cyp $2 b 10$ & \\
\hline & CD1/HFD & M & $6 \mathrm{w} / 14 \mathrm{w}$ & liver & $\begin{array}{l}\text { (-) Car, Pxr, Cyp2b10, Cyp2a4, Cyp3a11 } \\
\text { (0) Rxra }\end{array}$ & [214] \\
\hline Human & $\begin{array}{l}\text { Chronic kidney disease, } \\
\text { acute renal dysfunction }\end{array}$ & & adult & kidney & $(-)$ PXR & [218] \\
\hline & & & Fibrosis/Cirrl & & & \\
\hline \multirow{6}{*}{ Human } & $\begin{array}{l}\text { End-stage liver disease } \\
\text { (ALD, HCV, PSC) }\end{array}$ & & adult & liver & (-) CAR, RXR, AHR, PXR & [229] \\
\hline & HCV F3 fibrosis & & adult & liver & $(-) C A R, P X R$ & [231] \\
\hline & Steatosis, diabetes & & \multirow{3}{*}{ adult } & \multirow{3}{*}{ liver } & (0) CAR, PXR, FXR, SHP & \multirow{3}{*}{ [232] } \\
\hline & Alcohol cirrhosis & & & & (0) CAR, PXR, SHP (-) FXR & \\
\hline & Diabetic cirrhosis & & & & $(-)$ PXR, FXR (0) CAR, SHP & \\
\hline & NAFLD—fibrosis & & Pediatric & liver & $\begin{array}{l}\text { (+) CAR, PXR, GCNF, COUP-TF1, } \\
\text { NURR1, PPARs, Ers, TR, RAR/RXR }\end{array}$ & [233] \\
\hline \multirow{3}{*}{ Rat } & CCl4-induced cirrhosis & M & $3 \mathrm{w} / 12 \mathrm{w}$ & liver & $(-)$ PXR & [235] \\
\hline & $\begin{array}{l}\text { Thioacetamide-induced } \\
\text { cirrhosis }\end{array}$ & & $200 \mathrm{~g} / 7 \mathrm{w}$ & liver & (-) Pxr, Cyp3a (-) PXR, CYP3A & [238] \\
\hline & $\begin{array}{l}\text { SHRSP5/Dmcr } \\
\text { HFC }\end{array}$ & $\begin{array}{c}\mathrm{M} \\
\mathrm{F}\end{array}$ & $10 \mathrm{w} / 8 \mathrm{w}$ & liver & $\begin{array}{c}\text { (-) Car, Pxr (-) CAR, PXR (-) Cyp8b1 } \\
(-) \text { CYP8B1 } \\
(+) \text { Cyp7a1, Cyp7b1 (+) CYP7A1, } \\
\text { CYP7B1 }\end{array}$ & {$[239,240]$} \\
\hline Mouse & CCl4-induced cirrhosis & $\mathrm{M}$ & $25 \mathrm{~g} / 12 \mathrm{w}$ & $\begin{array}{c}\text { liver } \\
\text { intestine }\end{array}$ & (-) Pxr, Сyp3a & {$[236,237]$} \\
\hline \multicolumn{7}{|c|}{ Cholestasis } \\
\hline \multirow{6}{*}{ Human } & $\begin{array}{c}\text { Chronic cholestasis PBC } \\
\text { PSC }\end{array}$ & & adult & liver & (+) PXR (+) PXR & [242] \\
\hline & PBC grade III, IV & & adult & liver & $\begin{array}{c}\text { (0) PXR, CAR, FXR, RXR, SHP, HNF1 } \alpha, \\
H N F 4 \alpha \\
(-) \text { CYP7A1 (0) CYP8B1, CYP3A4 }\end{array}$ & [243] \\
\hline & Obstructive cholestasis & & adult & liver & $\begin{array}{c}\text { (+) PXR, RXR, VDR, HNF4 } \alpha, R A R \alpha \\
(+) \text { PXR, RXR, CAR, VDR, } H N F 4 \alpha, \\
R A R \alpha \\
(+) \text { CYP7B1 (+) CYP7B1, CYP8B1 }\end{array}$ & {$[244,245]$} \\
\hline & Obstructive cholestasis & & \multirow{3}{*}{ children } & \multirow{3}{*}{ liver } & (0) PXR (0) CAR (-) FXR, CYP7A1 & \multirow{3}{*}{ [246] } \\
\hline & Early stage & & & & & \\
\hline & Late stage & & & & (-) PXR (0) CAR, CYP3A4 & \\
\hline \multirow[b]{2}{*}{ Rat } & Bile duct ligation & $\mathrm{M}$ & $3 \mathrm{w}$ after surgery & liver & (-) PXR, CAR, Cyp3a1/2, CYP3Aa1/2 & [248] \\
\hline & $\begin{array}{l}\text { Bile duct ligation } \\
\text { Mild cholestasis } \\
\text { Severe cholestasis }\end{array}$ & M & $\begin{array}{l}2 \mathrm{w} \text { after surgery } \\
4 \mathrm{w} \text { after surgery }\end{array}$ & liver & $\begin{array}{c}\text { (+) Pxr, Car, PXR, CAR, Cyp3A1/2, } \\
\text { CYP3A1/2 } \\
\text { (-) Pxr, Car, PXR, CAR, Cyp3A1/2, } \\
\text { CYP3A1/2 }\end{array}$ & [251] \\
\hline \multirow{2}{*}{ Mouse } & $\begin{array}{l}\text { ANIT-induced } \\
\text { cholestasis }\end{array}$ & M & & liver & $\begin{array}{c}(+) \text { Pxr, Ppar } \alpha \\
(-) \text { Fxr, Ahr, Shp, Cyp7a1, Cyp8b1, } \\
\text { CYP8B1 }\end{array}$ & [249] \\
\hline & CA fed mice & M & $10 \mathrm{w} / 5 \mathrm{~d}$ & & $\begin{array}{c}\text { (+) Pxr, Fxr, Cyp3a11, Cyp7a1 } \\
\text { (-) Car }\end{array}$ & [250] \\
\hline
\end{tabular}

(+) induction, (-) inhibition, (0) not affected; S: sex; M: male, F: female, w: week, d: day; ALD: alcoholic liver disease; CA: cholic acid; HCV: hepatitis C virus; HFC: high-fat cholesterol; HFD: high-fat diet; PBC: primary biliary cirrhosis; PSC: primary sclerosis.

In bile duct-ligated rats, the nuclear expression of CAR and PXR is significantly reduced [248]. CAR, but not PXR, protein content is restored to normal levels by treatment with dexamethasone that reduces inflammation and oxidative stress [248]. Conversely, Pxr mRNA expression was induced in a mouse model of alpha-naphthylisothiocyanate-induced cholestasis [249] and in cholic acid-fed mice [250]. Gabbia et al. demonstrated that CAR and PXR expression levels are influenced by cholestasis severity following bile duct ligation in rats [251]. Indeed, PXR and CAR mRNA and protein 
expression levels were significantly increased in rats with mild cholestasis, and significantly reduced in rats with severe cholestasis. This suggests that the protective role of CAR and PXR is lost in the late stages of cholestasis following their downregulation [251].

\subsection{Cancer}

PXR expression is detected in ovarian [252], colon [253], esophageal [254], and breast carcinoma [255]; in prostate [256] and endometrial cancer [257]; and in sarcoma primary cells [60]. $P X R$ is specifically expressed in colorectal cancer stem cells, where it drives the expression of genes involved in self-renewal and chemoresistance [258]. Most chemoresistance-related enzymes, including CYP3A4, P-glycoproteins, and multidrug resistance proteins, are encoded by PXR target genes, and this may contribute to the acquired resistance to chemotherapy in colon, breast, and prostate cancer [259].

However, PXR pleiotropic effects in cancer have not been completely elucidated (reviewed in [28]). Recent studies showed that TGF- $\beta$ plays a key regulatory role in chronic liver diseases, including resistance to chemotherapy in many cancers. Bhagyaraj et al. demonstrated that in the HCC cell line HepG2, TGF- $\beta$ signaling enhances PXR endogenous expression. TGF- $\beta$ binding to its receptor triggers the activation of the non-canonical ERK signaling pathway. Activated ERK phosphorylates and activates the ETS1 transcription factor and enhances its binding to the PXR promoter [260]. The authors proposed that acquisition of drug resistance in response to TGF- $\beta$ can be mediated through the TGF- $\beta / E R K / E T S 1 / P X R$ signaling cascade, leading to increased expression of efflux transporters [260]. Conversely, expression of PXR mRNA and protein and of its target genes is reduced in DEN-induced hepatic cancer in mice, while CAR is not affected and RXR $\alpha$ is induced [261]. PXR downregulation is associated with upregulation of the inflammatory cytokines IL-6 and TNF $\alpha$. Moreover, HepG2 cells stably transfected with human or mouse PXR display reduced tumorigenic potential in vitro (cell migration, adhesion, invasion), suggesting that high PXR level may reduce tumorigenic potential in liver [261].

CAR role in cancer is still controversial. Phenobarbital, a CAR activator, promotes liver cancer in rodents; however, epidemiological studies have shown that phenobarbital does not increase the incidence of liver tumors in humans [262]. Like PXR, CAR is expressed in cancer cells and cancer stem cells $[28,259,263,264]$. CAR expression is reduced in $\mathrm{CD}^{2} 33^{+}$brain tumor stem cells, and its activation by CITCO induces its own expression and inhibits stem cell proliferation [265]. In a mouse model of lung carcinogenesis, macrophages and type I and II pneumocytes express CAR, whereas fibroblasts and endothelial cells do not [266]. Moreover, the number of CAR-positive tumor cells was lower in malignant than benign tumor lesions [266]. CAR mRNA expression is downregulated in hepatoblastoma and can be used as a predictor to assign unknown samples to the healthy or hepatoblastoma group with $100 \%$ accuracy [267].

\section{Xenobiotics}

PXR and CAR are activated by many exogenous compounds, including toxic molecules, to protect the body by facilitating their elimination through DMET regulation. While xenoreceptor activation in response to xenobiotics has been extensively studied, the impact on CAR and PXR expression has been poorly investigated. Data are summarized in Table 4.

\subsection{Nanoparticles}

The rapid expansion of nanomaterial technology has led to a growing interest in nanoscience and nanomedicine. As lungs and gastrointestinal tract are in constant contact with the external environment, much higher quantities of nanomaterials are accumulated in liver than in other organs.

Zinc oxide $(\mathrm{ZnO})$ and copper nanoparticles are frequently used as additives in animal feed, representing promising modalities in biomedical research and for clinical applications. Rats fed a diet supplemented with $\mathrm{ZnO}$ nanoparticles displayed liver and kidney injury [268]. Moreover, the concentrations of IL-6, INF- $\gamma$, and TNF- $\alpha$ in liver were increased, while Car mRNA was reduced in 
a dose-dependent manner. Pxr mRNA was only slightly induced [268]. Similarly, in rats, oral exposure to copper nanoparticles induced significant oxidative stress and inflammation, while the mRNA expression of Car and Pxr was significantly decreased in liver [269]. This was accompanied by activation of the NF-kB, MAPK, and Stat3 pathways. In rat brain, copper nanoparticles induce severe oxidative stress, decrease the expression of most CYP450 enzymes, and inhibit PXR and CAR protein expression [270].

Zebrafish embryos are protected against environmental pollutants, including quantum dots (QDs), thanks to adenosine triphosphate-binding cassette $(\mathrm{ABC})$ transporters. Expression of the mrp1 and mrp2 $\mathrm{ABC}$ transporters is increased in response to QDs. Moreover, the stronger upregulation of $p x r$ and $n r f 2$, compared with mrp gene induction, could be used as biomarker of QD toxicity [271].

Graphene oxide (GO) is a biocompatible and attractive nanomaterial for drug delivery. In vitro tests demonstrated that the mRNA expression of $P X R$ and of its target $A B C B 1$ is decreased in intestinal LS180 cells and in PHHs after incubation with GO [272]. PXR protein expression also is downregulated in PHHs, independently of the proteasomal pathway [272].

Many studies have investigated the harmful effects of a wide range of nanomaterials in liver, but the underlying mechanisms are still unclear. The analysis of PXR and CAR expression may help to better understand the activity of these new compounds [273].

\subsection{Environmental Pollutants and Food Contaminants}

Endocrine-disrupting chemicals interact with xenobiotics and drug-metabolizing enzymes, representing a global environmental and human health problem [274]. Besides their effect as "endocrine disruptors" that mimic or antagonize the action of endogenous signaling molecules through nuclear receptors $[275,276]$, these molecules might also affect xenoreceptor expression. In juvenile salmon, nonylphenol at environmentally relevant concentrations induce cyp3a and pxr mRNA expression in liver [277]. In rat primary hippocampal cell cultures, nonylphenol neurotoxic and apoptotic effects are accompanied by increased mRNA and protein levels of RXR $\alpha$, PXR, and CAR [278]. Glyphosate, the most widely used pesticide worldwide, can significantly increase the mRNA and protein expression of CAR, but not of PXR in piglets fed with a glyphosate level based on the maximum residue limits adopted by the Codex Alimentarius Commission. This is not accompanied by an increase of the expression of CAR and PXR target genes [279]. Exposure of HepG2 cells to cis-BF, a pyrethroid pesticide, increases PXR mRNA and protein levels, and activates PXR, contributing to cis-BF adverse effects on lipid accumulation [280].

Arsenic and heavy metals are environmental contaminants implicated in numerous human and animal pathological conditions. In the small intestine of CYP3A4 humanized transgenic mice, arsenite and its metabolites increased Pxr mRNA and CYP3A4 mRNA and protein levels [281]. Conversely, in rat and human hepatocytes, co-incubation with arsenite and rifampicin or phenobarbital (two CYP3A4 inducers) inhibited both basal and rifampicin- and phenobarbital-mediated CYP3A mRNA induction, but had no effect on PXR expression, and rather inhibited $R X R \alpha$ expression [282]. In embryonic zebrafish fibroblasts, heavy metal ions $\left(\mathrm{Ag}^{+}\right.$and $\left.\mathrm{Pb}^{+}\right)$dramatically (45-fold) induce pxr mRNA expression [283], suggesting a role for pxr in the heavy metal detoxication mechanism. 1-Octyl-3-methylimidazolium, a green substitute to conventional solvents, increases both Cyp3a and Pxr mRNA expression in mouse mammary carcinoma cell lines [284]. In addition to its natural presence at high concentrations in some areas, uranium has several civilian and military applications that could cause contamination of human populations through chronic ingestion. In rats chronically exposed to depleted uranium, Cyp3a and Pxr mRNA levels were found to be increased in brain, liver, and kidneys, while Cyp1a was not affected. Uranium strongly upregulates Car mRNA expression in lung [285].

Aflatoxin B1, one of the most common mycotoxins found in human foods and animal feed, is primarily hepatotoxic. In PHHs, aflatoxin B1 at non-cytotoxic concentrations caused a significant increase in CYP1As, CYP2B6, CYP3As, and CYP2C9 mRNA expression [286]. This was accompanied by $P X R, C A R$, and $A H R$ upregulation [286]. In the same cell model, patulin, another mycotoxin 
found in fruit, induced PXR and also CYP2B6, CYP3As, and CYP2C9 expression, but did not modify $C A R$ and $A H R$ levels [287]. Conversely, the mycotoxin ochratoxin A led to PXR protein decrease in PHHs via a proteasome-independent mechanism, and accelerated PXR mRNA degradation via increased miR-148a transcription [288]. In PXR-overexpressing HepG2 cells, a derivative of ochratoxin A that lacks the methyl group of the lactone-ring and the chlorine atom decreased PXR protein expression by $90 \%$, with low cytotoxicity [289]. The PXR expression plasmid contained only PXR coding sequence without the miR-148a recognition element [288], suggesting marginal changes in PXR mRNA expression. The mechanism of ochratoxin A-mediated inhibition of PXR expression needs to be explored.

\subsection{Drugs}

High doxorubicin doses damage rat gonadal epithelium, and this effect is associated with a strong upregulation of genes implicated in oxidative stress, including Pxr (8.2-fold increase) and Nrf2 (7.4-fold increase) [290]. Paclitaxel induces Car mRNA expression in the mouse lung cancer cell line E9, in the presence or absence of CAR ligand [291]. The antiretroviral drug efavirenz and the antituberculosis drug rifampicin reduce CAR mRNA expression in HepaRG cells, but not PXR mRNA level [292]. In the small benthic fish Mugilogobius abei, the mRNA expression of pxr and cyp3a was found to be increased following exposure to diclofenac [293].

\subsection{Food Components}

PXR and CAR are also activated by many herbal remedies, and are involved in drug-drug and drug-food interactions. The effect of food components has been mainly explored to determine their role in PXR expression in the context of intestinal inflammation. Liu et al. showed that compounds isolated from Chinese herbal medicines can modify PXR expression in the intestinal cell line LS174 [294]. Artemisinin [25], piperidine [295], tanshinone IIA [296], and isorhamnetin [297] are potential agonists and inducers of PXR mRNA and protein expression. In LS174 cells and in mice with dextran sodium sulfate-induced bowel disease, these compounds contribute to reducing the expression of inflammatory mediators and colon inflammation. Isorhamnetin represses the NF- $\mathrm{kB}$ pathway, with this potentially contributing to improvements in experimental colitis directly or through induction of PXR expression [297]. A fraction of tannin polymers isolated from the Chinese medicinal herb Paeoniae radix rubra inhibits PXR transcription in rat H4IIE liver cells, most likely by disrupting the activity of the transcription factor GR [298]. A combination of fish oil and indomethacin exerts synergistic anti-inflammatory and lipid-lowering effects in plasma and liver via several mechanisms, partly related to PXR upregulation [299]. The probiotic VSL\#3 reverses colitis-induced Pxr mRNA inhibition in mouse colon and adipose tissue [40]. In female mice fed a HFD and HCD, the combination of purified n-3 fatty acids (n-3) and SC-560 (SC), a cyclooxygenase-1-specific inhibitor, induced both Pxr and Fxr and reduced Fgfr4 expression, leading to upregulation of genes involved in bile synthesis and/or detoxification, and ameliorating nonalcoholic fatty liver disease. PXR expression and activation were also increased in Huh7 hepatoma cells incubated with this combination. FXR could mediate at least partly the effect of $n-3+$ SC through transactivation of PXR and its target genes [300]. A study to determine the role of the nutritional factor alpha-ketoglutarate (AKG) in PXR-mediated improvement of induced colitis showed that PXR activity might be increased through NF- $\mathrm{KB}$ downregulation that in turn de-represses PXR. It is unclear whether AKG acts as a regulator to modulate PXR activity [301]. It is important to strictly discriminate between PXR activation and expression in response to these molecules.

Plant extracts also affect CAR expression. Triptolide [302] and xanthohumol [303] negatively affect CAR mRNA and/or protein expression in rat liver and human hepatic cell lines. Moreover, Z-guggulsterone inhibits CAR expression in human microvessel endothelial cells [304]. Catalpol extracted from Rehmannia glutinosa reverses triptolide-mediated CAR inhibition [302]. Caffeine, one of the world's most consumed substances, causes a slight but significant increase of Car expression and 
potentiates the pleiotropic effects of TСРОВOP (the most potent mouse CAR ligand) in mouse liver, including hepatomegaly and hepatocyte proliferation [305].

Table 4. Xenobiotics that affect CAR and PXR expression.

\begin{tabular}{|c|c|c|c|c|}
\hline Compound & Target & Model & Effect/Mechanism & Reference \\
\hline \multicolumn{5}{|c|}{ Nanoparticles } \\
\hline $\mathrm{ZnO}$ & CAR & Rat liver in vivo & $\begin{array}{l}\text { Inhibition through inflammatory } \\
\text { signaling }\end{array}$ & [268] \\
\hline \multirow[t]{2}{*}{ Nano-copper } & \multirow[t]{2}{*}{ CAR PXR } & Rat liver in vivo & $\begin{array}{c}\text { Inflammatory signaling and oxidative } \\
\text { stress }\end{array}$ & [269] \\
\hline & & Rat brain & Inhibition through oxidative stress & [270] \\
\hline Quantum dots & PXR & Zebrafish embryos & Induction & [271] \\
\hline Graphene oxide & PXR & PHH LS174 cells & Proteasome-independent inhibition & [272] \\
\hline \multicolumn{5}{|c|}{ Environmental pollutants } \\
\hline \multirow{2}{*}{ Nonylphenol } & PXR & Juvenile salmon & Induction & [277] \\
\hline & CAR PXR & Rat hippocampal cells & Induction & {$[278]$} \\
\hline Glyphosate & CAR & Piglet liver & Induction & [279] \\
\hline cis-BF pyrethroid pesticide & PXR & Human HepG2 cells & Induction & [280] \\
\hline Benzo[a]pyrene & CAR & Rat hepatocytes & Induction & [141] \\
\hline Arsenic & PXR & Mouse small intestine & Induction & [281] \\
\hline Arsenite & PXR & Rat and human hepatocytes & No effect & {$[306]$} \\
\hline Heavy metal & PXR & Zebrafish fibroblasts & Induction & [283] \\
\hline \multirow{2}{*}{ Uranium } & PXR & Rat brain, liver, and kidney & Induction & \multirow{2}{*}{ [285] } \\
\hline & CAR & Rat lung & Induction & \\
\hline 1-octyl-3-methylimidazolium & PXR & $\begin{array}{l}\text { Mouse mammary carcinoma cell } \\
\text { line }\end{array}$ & Induction & [284] \\
\hline \multicolumn{5}{|c|}{ Food contaminants } \\
\hline Aflatoxin B1 & $\begin{array}{l}\text { CAR } \\
\text { PXR }\end{array}$ & PHH & Induction & [286] \\
\hline Patulin & PXR & PHH & Induction & [287] \\
\hline Ochratoxin A & PXR & PHH & $\begin{array}{l}\text { Proteasome-independent inhibition } \\
\text { through miR-148a }\end{array}$ & [288] \\
\hline Ochratoxin A derivative & PXR & PXR-overexpressing HepG2 cells & Inhibition & [289] \\
\hline \multicolumn{5}{|c|}{ Drugs } \\
\hline Diclofenac & PXR & Benthic small fish & Induction & [293] \\
\hline Doxorubicin & PXR & Rat gonad epithelium & Induction & [290] \\
\hline Paclitaxel & CAR & Mouse lung cancer cell line E9 & Induction & [266] \\
\hline Efavirenz & \multirow{2}{*}{ CAR } & \multirow{2}{*}{ Human HepaRG cells } & \multirow{2}{*}{ Inhibition } & \multirow[t]{2}{*}{ [292] } \\
\hline Rifampicin & & & & \\
\hline \multicolumn{5}{|c|}{ Food components } \\
\hline Artemisinin & PXR & Human LS174 cells & Induction & [25] \\
\hline Piperidine & PXR & Human LS174 cells & Induction & [295] \\
\hline Tanshione IIA & PXR & Human LS174 cells & Induction & [296] \\
\hline Isorhamnetin & PXR & Human LS174 cells & Induction & [297] \\
\hline Probiotics VSL\#3 & PXR & $\begin{array}{l}\text { Colon and adipose/induced colitis } \\
\text { mouse model }\end{array}$ & Reverse colitis-induced PXR inhibition & [40] \\
\hline A-ketoglutarate & PXR & Induced colitis & Induction & [301] \\
\hline Paeoniae radix rubra extracts & PXR & Rat hepatic cell line H4IIE & $\begin{array}{c}\text { Downregulation by disruption of GR } \\
\text { signaling }\end{array}$ & [298] \\
\hline $\begin{array}{l}\mathrm{n}-3 \text { fatty acids }(\mathrm{n}-3)+ \\
\text { SC-560 }\end{array}$ & PXR & $\begin{array}{l}\text { HFD mice liver } \\
\text { Human Huh7 cells }\end{array}$ & Induction through FXR signaling? & [300] \\
\hline Fish oil + indomethacin & PXR & Liver & Induction & [299] \\
\hline Tripolide & CAR & $\begin{array}{c}\text { Rat liver } \\
\text { Human L-02 and HepG2 cells }\end{array}$ & Inhibition & [302] \\
\hline Z-guggulsterone & CAR & $\begin{array}{l}\text { Human brain micro-vessel } \\
\text { endothelial cells }\end{array}$ & Inhibition & [304] \\
\hline Xanthohumol & CAR & Rat liver & Inhibition & [303] \\
\hline Catalpol & CAR & $\begin{array}{c}\text { Rat liver } \\
\text { Human L-02 and HepG2 cells }\end{array}$ & Reverse tripolide-mediated inhibition & [302] \\
\hline Caffeine & CAR & Mouse liver & Induction & [305] \\
\hline
\end{tabular}




\section{Conclusions}

The expression of PXR and CAR is influenced by a wide range of physiological, pathological, and environmental stimuli and is controlled by complex regulatory mechanisms that are not well are described and that involve transcription factors and post-transcriptional and epigenetic modifications.

The observed expression variations are often small, in contrast to what reported for their target genes. R.K. Tyagi's group proposed that PXR gene expression is tightly regulated in physiological conditions by "an interplay between activators and repressors so as to maintain a low cellular level of PXR protein" [151]. In contrast, high PXR expression level could be associated with aberrant homeostasis, diseases, and exposure to some xenobiotics. As described for PXR, CAR expression is low, and its altered in pathological situations and in response to environmental cues. However, changes in CAR and PXR expression are not linear during disease progression. The modification of their expression is probably associated with the disease severity, as suggested by studies on cholestatic disorders. CAR and PXR may exert a protective role in the early stage of hepatic diseases, but this effect may be lost during disease progression. Their expression should be monitored throughout the disease course.

It is well established that PXR and CAR bind to different chemical compounds and exhibit species and isoform selectivity [307]. Similarly, some of their physiological functions show species differences [4]. However, virtually no study has investigated whether the regulation of their expression is species-specific. It should be noted that regulatory pathways, such as the GR, NF-kB, and PGC- $1 \alpha / \mathrm{PPAR} \alpha$ signaling cascades, seem to be conserved at least between rodents and humans.

Most of the studies on CAR and PXR expression focused on their mRNA expression. Due to the lack of efficient and specific antibodies, their protein expression has been minimally explored. Consequently, many aspects of PXR and CAR protein expression regulation are unknown, for instance protein half-life and degradation, translation efficiency, variants, and impact of post-translational modifications on protein stability.

The PXR and CAR activities are controlled by a crosstalk with transcription factors and other nuclear receptors. Most of them also modulate the expression of PXR and CAR, a level of regulation that is still poorly studied. Because of their important roles in physiological and pathological conditions, understanding the regulatory mechanisms of CAR and PXR transcription is crucial to decipher their many functional roles in health and in the development of immune, metabolic, and malignant diseases.

Funding: This work was supported by the French Agence Nationale de la Recherche ANR-17-CE18-0035.

Conflicts of Interest: The authors declare no conflict of interest.

\section{References}

1. Yan, J.; Xie, W. A brief history of the discovery of PXR and CAR as xenobiotic receptors. Acta Pharm. Sin. B 2016, 6, 450-452. [CrossRef]

2. Oladimeji, P.O.; Chen, T. PXR: More than just a master xenobiotic receptor. Mol. Pharmacol. 2017, 93, $119-127$. [CrossRef] [PubMed]

3. Banerjee, M.; Robbins, D.; Chen, T. Targeting xenobiotic receptors PXR and CAR in human diseases. Drug Discov. Today 2015, 20, 618-628. [CrossRef] [PubMed]

4. Mackowiak, B.; Hodge, J.; Stern, S.; Wang, H. The roles of xenobiotic receptors: Beyond chemical disposition. Drug Metab. Dispos. 2018, 46, 1361-1371. [CrossRef] [PubMed]

5. Xiao, L.; Nickbarg, E.; Wang, W.; Thomas, A.; Ziebell, M.; Prosise, W.W.; Lesburg, C.A.; Taremi, S.S.; Gerlach, V.L.; Le, H.V.; et al. Evaluation of in vitro PXR-based assays and in silico modeling approaches for understanding the binding of a structurally diverse set of drugs to PXR. Biochem. Pharmacol. 2011, 81, 669-679. [CrossRef]

6. Yang, H.; Wang, H. Signaling control of the constitutive androstane receptor (CAR). Protein Cell 2014, 5, 113-123. [CrossRef] 
7. Balasubramaniyan, N.; Shahid, M.; Suchy, F.J.; Ananthanarayanan, M. Multiple mechanisms of ontogenic regulation of nuclear receptors during rat liver development. Am. J. Physiol. Liver Physiol. 2005, 288, G251-G260. [CrossRef]

8. Xu, S.-F.; Hu, A.-L.; Xie, L.; Liu, J.-J.; Wu, Q.; Liu, J. Age-associated changes of cytochrome P450 and related phase-2 gene/proteins in livers of rats. PeerJ 2019, 7, e7429. [CrossRef]

9. Chen, S.; He, N.; Yu, J.; Li, L.; Hu, Y.; Deng, R.; Zhong, S.; Shen, L. Post-transcriptional regulation by miR-137 underlies the low abundance of CAR and low rate of bilirubin clearance in neonatal mice. Life Sci. 2014, 107, 8-13. [CrossRef]

10. Greger, D.; Philipona, C.; Blum, J. Ontogeny of mRNA abundance of nuclear receptors and nuclear receptor target genes in young cattle. Domest. Anim. Endocrinol. 2006, 31, 76-87. [CrossRef]

11. Marques, C.; Roberto, V.P.; Granadeiro, L.; Trindade, M.; Gavaia, P.J.; Laizé, V.; Cancela, M.L.; Fernández, I. The xenobiotic sensor PXR in a marine flatfish species (Solea senegalensis): Gene expression patterns and its regulation under different physiological conditions. Mar. Environ. Res. 2017, 130, 187-199. [CrossRef]

12. Funakoshi, N.; Duret, C.; Pascussi, J.-M.; Blanc, P.; Maurel, P.; Daujat-Chavanieu, M.; Gerbal-Chaloin, S. Comparison of hepatic-like cell production from human embryonic stem cells and adult liver progenitor cells: CAR transduction activates a battery of detoxification genes. Stem Cell Rev. Rep. 2011, 7, 518-531. [CrossRef]

13. Betts, S.; Björkhem-Bergman, L.; Rane, A.; Ekström, L. Expression of CYP3A4 and CYP3A7 in human foetal tissues and its correlation with nuclear receptors. Basic Clin. Pharmacol. Toxicol. 2015, 117, 261-266. [CrossRef] [PubMed]

14. Chen, F.; Zamule, S.M.; Coslo, D.M.; Chen, T.; Omiecinski, C.J. The human constitutive androstane receptor promotes the differentiation and maturation of hepatic-like cells. Dev. Biol. 2013, 384, 155-165. [CrossRef] [PubMed]

15. Miki, Y.; Suzuki, T.; Tazawa, C.; Blumberg, B.; Sasano, H. Steroid and xenobiotic receptor (SXR), cytochrome P450 3A4 and multidrug resistance gene 1 in human adult and fetal tissues. Mol. Cell. Endocrinol. 2005, 231, 75-85. [CrossRef] [PubMed]

16. Chen, C.; Soto-Gutierrez, A.; Baptista, P.M.; Spee, B. Biotechnology challenges to in vitro maturation of hepatic stem cells. Gastroenterology 2018, 154, 1258-1272. [CrossRef]

17. Godoy, P.; Schmidt-Heck, W.; Natarajan, K.; Lucendo-Villarin, B.; Szkolnicka, D.; Asplund, A.; Björquist, P.; Widera, A.; Stöber, R.; Campos, G.; et al. Gene networks and transcription factor motifs defining the differentiation of stem cells into hepatocyte-like cells. J. Hepatol. 2015, 63, 934-942. [CrossRef]

18. Xie, W.; Barwick, J.L.; Downes, M.; Blumberg, B.; Simon, C.M.; Nelson, M.C.; Neuschwander-Tetri, B.A.; Brunt, E.M.; Guzelian, P.S.; Evans, R.M. Humanized xenobiotic response in mice expressing nuclear receptor SXR. Nat. Cell Biol. 2000, 406, 435-439. [CrossRef]

19. Wei, P.; Zhang, J.; Egan-Hafley, M.; Liang, S.; Moore, D.D. The nuclear receptor CAR mediates specific xenobiotic induction of drug metabolism. Nat. Cell Biol. 2000, 407, 920-923. [CrossRef]

20. Waxman, D.J.; Holloway, M.G. Sex differences in the expression of hepatic drug metabolizing enzymes. Mol. Pharmacol. 2009, 76, 215-228. [CrossRef]

21. Lu, Y.-F.; Jin, T.; Xu, Y.; Zhang, D.; Wu, Q.; Zhang, Y.-K.J.; Liu, J. Sex differences in the circadian variation of cytochrome P450 genes and corresponding nuclear receptors in mouse liver. Chronobiol. Int. 2013, 30, 1135-1143. [CrossRef]

22. Kennedy, M.J. Hormonal regulation of hepatic drug-metabolizing enzyme activity during adolescence. Clin. Pharmacol. Ther. 2008, 84, 662-673. [CrossRef] [PubMed]

23. Zhang, H.; LeCulyse, E.; Liu, L.; Hu, M.; Matoney, L.; Zhu, W.; Yan, B. Rat pregnane X receptor: Molecular cloning, tissue distribution, and xenobiotic regulation. Arch. Biochem. Biophys. 1999, 368, 14-22. [CrossRef] [PubMed]

24. Nishimura, M.; Naito, S.; Yokoi, T. Tissue-specific mRNA expression profiles of human nuclear receptor subfamilies. Drug Metab. Pharmacokinet. 2004, 19, 135-149. [CrossRef] [PubMed]

25. Hu, D.; Wang, Y.; Chen, Z.; Ma, Z.-C.; You, Q.; Zhang, X.; Zhou, T.; Xiao, Y.; Liang, Q.; Tan, H.; et al. Artemisinin protects against dextran sulfate-sodium-induced inflammatory bowel disease, which is associated with activation of the pregnane X receptor. Eur. J. Pharmacol. 2014, 738, 273-284. [CrossRef]

26. Pollock, C.B.; Rogatcheva, M.B.; Schook, L.B. Comparative genomics of xenobiotic metabolism: A porcine-human PXR gene comparison. Mamm. Genome 2007, 18, 210-219. [CrossRef] 
27. Wassmur, B.; Gräns, J.; Kling, P.; Celander, M.C. Interactions of pharmaceuticals and other xenobiotics on hepatic pregnane $X$ receptor and cytochrome $\mathrm{P} 450$ 3A signaling pathway in rainbow trout (Oncorhynchus mykiss). Aquat. Toxicol. 2010, 100, 91-100. [CrossRef]

28. Xing, Y.; Yan, J.; Niu, Y. PXR: A center of transcriptional regulation in cancer. Acta Pharm. Sin. B 2019, 10, 197-206. [CrossRef]

29. Hudson, G.M.; Flannigan, K.L.; Erickson, S.L.; Vicentini, F.A.; Zamponi, A.; Hirota, C.L.; Alston, L.; Altier, C.; Ghosh, S.; Rioux, K.P.; et al. Constitutive androstane receptor regulates the intestinal mucosal response to injury. Br. J. Pharmacol. 2017, 174, 1857-1871. [CrossRef]

30. Chirulli, V.; Longo, V.; Marini, S.; Mazzaccaro, A.; Fiorio, R.; Gervasi, P.G. CAR and PXR expression and inducibility of CYP2B and CYP3A activities in rat and rabbit lungs. Life Sci. 2005, 76, 2535-2546. [CrossRef]

31. Baes, M.; Gulick, T.; Choi, H.S.; Martinoli, M.G.; Simha, D.; Moore, D.D. A new orphan member of the nuclear hormone receptor superfamily that interacts with a subset of retinoic acid response elements. Mol. Cell. Biol. 1994, 14, 1544-1552. [CrossRef] [PubMed]

32. Choi, H.-S.; Chung, M.; Tzameli, I.; Simha, D.; Lee, Y.-K.; Seol, W.; Moore, D.D. Differential transactivation by two isoforms of the orphan nuclear hormone receptor CAR. J. Biol. Chem. 1997, 272, 23565-23571. [CrossRef] [PubMed]

33. Li, Z.; Kruijt, J.K.; Van Der Sluis, R.J.; Van Berkel, T.J.C.; Hoekstra, M.; Der Sluis, R.J.V.; Berkel, T.J.C.V. Nuclear receptor atlas of female mouse liver parenchymal, endothelial, and Kupffer cells. Physiol. Genom. 2013, 45, 268-275. [CrossRef] [PubMed]

34. Lu, P.; Prost, S.; Caldwell, H.; Tugwood, J.D.; Betton, G.R.; Harrison, D.J. Microarray analysis of gene expression of mouse hepatocytes of different ploidy. Mamm. Genome 2007, 18, 617-626. [CrossRef]

35. Wallace, K.; Cowie, D.E.; Konstantinou, D.K.; Hill, S.J.; Tjelle, T.E.; Axon, A.; Koruth, M.; White, S.A.; Carlsen, H.; Mann, D.A.; et al. The PXR is a drug target for chronic inflammatory liver disease. J. Steroid Biochem. Mol. Biol. 2010, 120, 137-148. [CrossRef]

36. Haughton, E.L.; Tucker, S.J.; Marek, C.J.; Durward, E.; Leel, V.; Bascal, Z.; Monaghan, T.M.; Koruth, M.; Collie-Duguid, E.; Mann, D.A.; et al. Pregnane X receptor activators inhibit human hepatic stellate cell transdifferentiation in vitro. Gastroenterology 2006, 131, 194-209. [CrossRef]

37. Renga, B.; Daniela, F.; D'Amore, C.; Schiaroli, E.; Carino, A.; Baldelli, F.; Fiorucci, S. HIV-1 infection is associated with changes in nuclear receptor transcriptome, pro-inflammatory and lipid profile of monocytes. BMC Infect. Dis. 2012, 12, 274. [CrossRef]

38. Schote, A.B.; Turner, J.D.; Schiltz, J.; Muller, C.P. Nuclear receptors in human immune cells: Expression and correlations. Mol. Immunol. 2007, 44, 1436-1445. [CrossRef] [PubMed]

39. Hudson, G.M.; Flannigan, K.L.; Venu, V.K.P.; Alston, L.; Sandall, C.F.; Macdonald, J.A.; Muruve, D.A.; Chang, T.K.; Mani, S.; A Hirota, S. Pregnane X receptor activation triggers rapid atp release in primed macrophages that mediates NLRP3 inflammasome activation. J. Pharmacol. Exp. Ther. 2019, 370, 44-53. [CrossRef]

40. Mencarelli, A.; Distrutti, E.; Renga, B.; D’Amore, C.; Cipriani, S.; Palladino, G.; Donini, A.; Ricci, P.; Fiorucci, S. Probiotics modulate intestinal expression of nuclear receptor and provide counter-regulatory signals to inflammation-driven adipose tissue activation. PLoS ONE 2011, 6, e22978. [CrossRef]

41. Takeuchi, Y.; Kito, A.; Itoh, S.; Naruse, H.; Fujikawa, J.; Sadek, K.M.; Akiyama, S.; Yamashiro, T.; Wakisaka, S.; Abe, M. Kruppel-like factor 4 represses osteoblast differentiation via ciliary Hedgehog signaling. Exp. Cell Res. 2018, 371, 417-425. [CrossRef]

42. Pavek, P.; Smutný, T. Nuclear receptors in regulation of biotransformation enzymes and drug transporters in the placental barrier. Drug Metab. Rev. 2013, 46, 19-32. [CrossRef]

43. Torres-Vergara, P.; Ho, Y.S.; Espinoza, F.; Nualart, F.; Escudero, C.; Penny, J. The constitutive androstane receptor and pregnane $X$ receptor in the brain. Br. J. Pharmacol. 2020, 177, 2666-2682. [CrossRef] [PubMed]

44. Auerbach, S.S.; Ramsden, R.; Stoner, M.A.; Verlinde, C.; Hassett, C.; Omiecinski, C.J. Alternatively spliced isoforms of the human constitutive androstane receptor. Nucleic Acids Res. 2003, 31, 3194-3207. [CrossRef]

45. Jinno, H.; Tanaka-Kagawa, T.; Hanioka, N.; Ishida, S.; Saeki, M.; Soyama, A.; Itoda, M.; Nishimura, T.; Saito, Y.; Ozawa, S.; et al. Identification of novel alternative splice variants of human constitutive androstane receptor and characterization of their expression in the liver. Mol. Pharmacol. 2004, 65, 496-502. [CrossRef] 
46. Lamba, J.K.; Lamba, V.; Yasuda, K.; Lin, Y.S.; Assem, M.; Thompson, E.; Strom, S.C.; Schuetz, E. Expression of constitutive androstane receptor splice variants in human tissues and their functional consequences. J. Pharmacol. Exp. Ther. 2004, 311, 811-821. [CrossRef] [PubMed]

47. DeKeyser, J.G.; Laurenzana, E.M.; Peterson, E.C.; Chen, T.; Omiecinski, C.J. Selective phthalate activation of naturally occurring human constitutive androstane receptor splice variants and the pregnane $\mathrm{X}$ receptor. Toxicol. Sci. 2011, 120, 381-391. [CrossRef] [PubMed]

48. DeKeyser, J.G.; Stagliano, M.C.; Auerbach, S.S.; Prabhu, K.S.; Jones, A.D.; Omiecinski, C.J. Di(2-ethylhexyl) phthalate is a highly potent agonist for the human constitutive androstane receptor splice variant CAR2. Mol. Pharmacol. 2009, 75, 1005-1013. [CrossRef]

49. Rondini, E.A.; Duniec-Dmuchowski, Z.; Kocarek, T.A. Nonsterol isoprenoids activate human constitutive androstane receptor in an isoform-selective manner in primary cultured mouse hepatocytes. Drug Metab. Dispos. 2016, 44, 595-604. [CrossRef]

50. Sharma, A.; Yun, H.; Jyotsana, N.; Chaturvedi, A.; Schwarzer, A.; Yung, E.; Lai, C.K.; Kuchenbauer, F.; Argiropoulos, B.; Görlich, K.; et al. Constitutive IRF8 expression inhibits AML by activation of repressed immune response signaling. Leukemia 2014, 29, 157-168. [CrossRef]

51. Ross, J.; Plummer, S.M.; Rode, A.; Scheer, N.; Bower, C.C.; Vogel, O.; Henderson, C.J.; Wolf, C.R.; Elcombe, C. Human Constitutive Androstane Receptor (CAR) and Pregnane X Receptor (PXR) support the hypertrophic but not the hyperplastic response to the murine nongenotoxic hepatocarcinogens phenobarbital and chlordane in vivo. Toxicol. Sci. 2010, 116, 452-466. [CrossRef]

52. Arnold, K.; Eichelbaum, M.; Burk, O. Alternative splicing affects the function and tissue-specific expression of the human constitutive androstane receptor. Nucl. Recept. 2004, 2, 1. [CrossRef]

53. Gray, M.A.; Peacock, J.N.; Squires, E.J. Characterization of the porcine constitutive androstane receptor (CAR) and its splice variants. Xenobiotica 2009, 39, 915-930. [CrossRef]

54. Fukuen, S.; Fukuda, T.; Matsuda, H.; Sumida, A.; Yamamoto, I.; Inaba, T.; Azuma, J. Identification of the novel splicing variants for the hPXR in human livers. Biochem. Biophys. Res. Commun. 2002, 298, $433-438$. [CrossRef]

55. Lamba, J.K. PXR (NR1I2): Splice variants in human tissues, including brain, and identification of neurosteroids and nicotine as PXR activators. Toxicol. Appl. Pharmacol. 2004, 199, 251-265. [CrossRef]

56. Gardner-Stephen, D.; Heydel, J.-M.; Goyal, A.; Lu, Y.; Xie, W.; Lindblom, T.; MacKenzie, P.I.; Radominska-Pandya, A. Human PXR variants and their differential effects on the regulation of human udp-glucuronosyltransferase gene expression. Drug Metab. Dispos. 2004, 32, 340-347. [CrossRef]

57. Kliewer, S.; Moore, J.T.; Wade, L.; Staudinger, J.L.; Watson, M.; Jones, S.; McKee, D.D.; Oliver, B.B.; Willson, T.M.; Zetterström, R.H.; et al. An orphan nuclear receptor activated by pregnanes defines a novel steroid signaling pathway. Cell 1998, 92, 73-82. [CrossRef]

58. Brewer, C.T.; Chen, T. PXR variants: The impact on drug metabolism and therapeutic responses. Acta Pharm. Sin. B 2016, 6, 441-449. [CrossRef]

59. Breuker, C.; Planque, C.; Rajabi, F.; Nault, J.-C.; Couchy, G.; Zucman-Rossi, J.; Evrard, A.; Kantar, J.; Chevet, E.; Bioulac-Sage, P.; et al. Characterization of a novel PXR isoform with potential dominant-negative properties. J. Hepatol. 2014, 61, 609-616. [CrossRef]

60. Mensah-Osman, E.J.; Thomas, D.G.; Tabb, M.M.; Larios, J.M.; Hughes, D.P.; Giordano, T.J.; Ms, M.L.L.; Rae, J.M.; Blumberg, B.; Hollenberg, P.F.; et al. Expression levels and activation of a PXR variant are directly related to drug resistance in osteosarcoma cell lines. Cancer 2007, 109, 957-965. [CrossRef]

61. Liu, Y.; Ji, W.; Yin, Y.; Fan, L.; Zhang, J.; Yun, H.; Wang, N.; Li, Q.; Wei, Z.; Ouyang, D.; et al. The effects of splicing variant of PXR PAR-2 on CYP3A4 and MDR1 mRNA expressions. Clin. Chim. Acta 2009, 403, 142-144. [CrossRef] [PubMed]

62. Matic, M.; Corradin, A.P.; Tsoli, M.; Clarke, S.J.; Polly, P.; Robertson, G.R. The alternatively spliced murine pregnane $X$ receptor isoform, $\mathrm{mPXR} \Delta 171-211$ exhibits a repressive action. Int. J. Biochem. Cell Biol. 2010, 42, 672-682. [CrossRef] [PubMed]

63. Gray, M.; Pollock, C.B.; Schook, L.B.; Squires, E.J. Characterization of porcine pregnane X receptor, farnesoid $X$ receptor and their splice variants. Exp. Biol. Med. 2010, 235, 718-736. [CrossRef]

64. Burris, T.P. Nuclear hormone receptors for heme: REV-ERB $\alpha$ and REV-ERB $\beta$ are ligand-regulated components of the mammalian clock. Mol. Endocrinol. 2008, 22, 1509-1520. [CrossRef] 
65. Mohawk, J.A.; Green, C.B.; Takahashi, J.S. Central and peripheral circadian clocks in mammals. Annu. Rev. Neurosci. 2012, 35, 445-462. [CrossRef]

66. Yang, X.; Downes, M.; Yu, R.T.; Bookout, A.L.; He, W.; Straume, M.; Mangelsdorf, D.J.; Evans, R.M. Nuclear receptor expression links the circadian clock to metabolism. Cell 2006, 126, 801-810. [CrossRef] [PubMed]

67. Zhang, Y.-K.J.; Yeager, R.L.; Klaassen, C.D. Circadian expression profiles of drug-processing genes and transcription factors in mouse liver. Drug Metab. Dispos. 2009, 37, 106-115. [CrossRef] [PubMed]

68. Chan, G.N.; Saldivia, V.; Yang, Y.; Pang, H.; Lannoy, L.; Bendayan, R. In vivo induction of P-glycoprotein expression at the mouse blood-brain barrier: An intracerebral microdialysis study. J. Neurochem. 2013, 127, 342-352. [CrossRef]

69. Gachon, F.; Olela, F.F.; Schaad, O.; Descombes, P.; Schibler, U. The circadian PAR-domain basic leucine zipper transcription factors DBP, TEF, and HLF modulate basal and inducible xenobiotic detoxification. Cell Metab. 2006, 4, 25-36. [CrossRef] [PubMed]

70. De Vries, E.M.; Oosterman, J.E.; Eggink, H.M.; De Goede, P.; Şen, S..; Foppen, E.; Boudzovitch-Surovtseva, O.; Boelen, A.; Romijn, J.A.; LaFleur, S.E.; et al. Effects of meal composition and meal timing on the expression of genes involved in hepatic drug metabolism in rats. PLOS ONE 2017, 12, e0185520. [CrossRef]

71. Kanno, Y.; Otsuka, S.; Hiromasa, T.; Nakahama, T.; Inouye, Y. Diurnal difference in CAR mRNA expression. Nucl. Recept. 2004, 2, 6. [CrossRef]

72. Patel, R.D.; Hollingshead, B.D.; Omiecinski, C.J.; Perdew, G.H. Aryl-hydrocarbon receptor activation regulates constitutive androstane receptor levels in murine and human liver. Hepatology 2007, 46, 209-218. [CrossRef]

73. Richardson, V.M.; Santostefano, M.J.; Birnbaum, L.S. Daily cycle of bHLH-PAS proteins, Ah receptor and arnt, in multiple tissues of female sprague-dawley rats. Biochem. Biophys. Res. Commun. 1998, 252, 225-231. [CrossRef]

74. Lin, Y.; Wang, S.; Zhou, Z.; Guo, L.; Yu, F.; Wu, B. Bmal1 regulates circadian expression of cytochrome P450 3a11 and drug metabolism in mice. Commun. Biol. 2019, 2, 378. [CrossRef]

75. Kang, H.S.; Angers, M.; Beak, J.Y.; Wu, X.; Gimble, J.M.; Wada, T.; Xie, W.; Collins, J.B.; Grissom, S.F.; Jetten, A.M. Gene expression profiling reveals a regulatory role for ROR $\alpha$ and $\mathrm{ROR} \gamma$ in phase I and phase II metabolism. Physiol. Genom. 2007, 31, 281-294. [CrossRef] [PubMed]

76. Liu, C.; Li, S.; Liu, T.; Borjigin, J.; Lin, J.D. Transcriptional coactivator PGC-1 $\alpha$ integrates the mammalian clock and energy metabolism. Nat. Cell Biol. 2007, 447, 477-481. [CrossRef]

77. Lamia, K.A.; Papp, S.J.; Yu, R.T.; Barish, G.D.; Uhlenhaut, N.H.; Jonker, J.W.; Downes, M.; Evans, R.M. Cryptochromes mediate rhythmic repression of the glucocorticoid receptor. Nat. Cell Biol. 2011, 480, 552-556. [CrossRef]

78. Kettner, N.M.; Voicu, H.; Finegold, M.J.; Coarfa, C.; Sreekumar, A.; Putluri, N.; Katchy, C.A.; Lee, C.; Moore, D.D.; Fu, L. Circadian homeostasis of liver metabolism suppresses hepatocarcinogenesis. Cancer Cell 2016, 30, 909-924. [CrossRef]

79. Ben-Moshe, S.; Itzkovitz, S. Spatial heterogeneity in the mammalian liver. Nat. Rev. Gastroenterol. Hepatol. 2019, 16, 395-410. [CrossRef]

80. Benhamouche, S.; Decaens, T.; Godard, C.; Chambrey, R.; Rickman, D.S.; Moinard, C.; Vasseur-Cognet, M.; Kuo, C.J.; Kahn, A.; Perret, C.; et al. Apc tumor suppressor gene is the "Zonation-Keeper" of mouse liver. Dev. Cell 2006, 10, 759-770. [CrossRef]

81. Rocha, A.S.; Vidal, V.; Mertz, M.; Kendall, T.J.; Charlet, A.; Okamoto, H.; Schedl, A. The angiocrine factor Rspondin3 is a key determinant of liver zonation. Cell Rep. 2015, 13, 1757-1764. [CrossRef]

82. Braeuning, A.; Ittrich, C.; Köhle, C.; Hailfinger, S.; Bonin, M.; Buchmann, A.; Schwarz, M. Differential gene expression in periportal and perivenous mouse hepatocytes. FEBS J. 2006, 273, 5051-5061. [CrossRef] [PubMed]

83. Braeuning, A.; Sanna, R.; Huelsken, J.; Schwarz, M. Inducibility of drug-metabolizing enzymes by xenobiotics in mice with liver-specific knockout of Ctnnb1. Drug Metab. Dispos. 2009, 37, 1138-1145. [CrossRef] [PubMed]

84. Gougelet, A.; Torre, C.; Veber, P.; Sartor, C.; Bachelot, L.; Denechaud, P.-D.; Godard, C.; Moldes, M.; Burnol, A.; Dubuquoy, C.; et al. T-cell factor 4 and beta-catenin chromatin occupancies pattern zonal liver metabolism in mice. Hepatology 2014, 59, 2344-2357. [CrossRef] [PubMed]

85. Kumari, S.; Mukhopadhyay, G.; Tyagi, R.K. Transcriptional regulation of mouse PXR gene: An interplay of transregulatory factors. PLoS ONE 2012, 7, e44126. [CrossRef] 
86. Gerbal-Chaloin, S.; Dumé, A.-S.; Briolotti, P.; Klieber, S.; Raulet, E.; Duret, C.; Fabre, J.-M.; Ramos, J.; Maurel, P.; Daujat-Chavanieu, M. The WNT/ $\beta$-Catenin pathway is a transcriptional regulator of CYP2E1,CYP1A2, and aryl hydrocarbon receptor gene expression in primary human hepatocytes. Mol. Pharmacol. 2014, 86, 624-634. [CrossRef]

87. Thomas, M.; Bayha, C.; Vetter, S.; Hofmann, U.; Schwarz, M.; Zanger, U.M.; Braeuning, A. Activating and inhibitory functions of WNT/beta-Catenin in the induction of cytochromes $\mathrm{P} 450$ by nuclear receptors in HepaRG cells. Mol. Pharmacol. 2015, 87, 1013-1020. [CrossRef]

88. Jaworski, M.; Buchmann, A.; Bauer, P.; Riess, O.; Schwarz, M. B-Raf and Ha-ras mutations in chemically induced mouse liver tumors. Oncogene 2004, 24, 1290-1295. [CrossRef]

89. Hailfinger, S.; Jaworski, M.; Braeuning, A.; Buchmann, A.; Schwarz, M. Zonal gene expression in murine liver: Lessons from tumors. Hepatology 2006, 43, 407-414. [CrossRef]

90. Stahl, S.; Ittrich, C.; Marx-Stoelting, P.; Köhle, C.; Altug-Teber, Ö.; Riess, O.; Bonin, M.; Jobst, J.; Kaiser, S.; Buchmann, A.; et al. Genotype-phenotype relationships in hepatocellular tumors from mice and man. Hepatology 2005, 42, 353-361. [CrossRef]

91. Braeuning, A.; Ittrich, C.; Köhle, C.; Buchmann, A.; Schwarz, M. Zonal gene expression in mouse liver resembles expression patterns of Ha-ras and beta-catenin mutated hepatomas. Drug Metab. Dispos. 2007, 35, 503-507. [CrossRef]

92. Braeuning, A.; Kollotzek, F.; Zeller, E.; Knorpp, T.; Templin, M.F.; Schwarz, M. Mouse hepatomas with Ha-ras and B-raf mutations differ in mitogen-activated protein kinase signaling and response to constitutive androstane receptor activation. Drug Metab. Dispos. 2018, 46, 1462-1465. [CrossRef]

93. Braeuning, A.; Menzel, M.; Kleinschnitz, E.-M.; Harada, N.; Tamai, Y.; Köhle, C.; Buchmann, A.; Schwarz, M. Serum components and activated Ha-ras antagonize expression of perivenous marker genes stimulated by beta-catenin signaling in mouse hepatocytes. FEBS J. 2007, 274, 4766-4777. [CrossRef]

94. Bachleda, P.; Vrza, R.; Dvorak, Z. Activation of MAPKs influences the expression of drug-metabolizing enzymes in primary human hepatocytes. Gen. Physiol. Biophys. 2009, 28, 316-320. [CrossRef]

95. De Boussac, H.; Gondeau, C.; Briolotti, P.; Duret, C.; Treindl, F.; Römer, M.; Fabre, J.-M.; Herrero, A.; Ramos, J.; Maurel, P.; et al. Epidermal growth factor represses constitutive androstane receptor expression in primary human hepatocytes and favors regulation by pregnane X receptor. Drug Metab. Dispos. 2017, 46, $223-236$. [CrossRef] [PubMed]

96. Halpern, K.B.; Shenhav, R.; Matcovitch-Natan, O.; Tóth, B.; Lemze, D.; Golan, M.; Massasa, E.E.; Baydatch, S.; Landen, S.; Moor, A.E.; et al. Single-cell spatial reconstruction reveals global division of labour in the mammalian liver. Nat. Cell Biol. 2017, 542, 352-356. [CrossRef] [PubMed]

97. Halpern, K.B.; Shenhav, R.; Matcovitch-Natan, O.; Tóth, B.; Lemze, D.; Golan, M.; Massasa, E.; Baydatch, S.; Landen, S.; Moor, A.; et al. Erratum: Single-cell spatial reconstruction reveals global division of labour in the mammalian liver. Nature 2017, 543, 742. [CrossRef]

98. Yan, J.; Chen, B.; Lu, J.; Xie, W. Deciphering the roles of the constitutive androstane receptor in energy metabolism. Acta Pharmacol. Sin. 2014, 36, 62-70. [CrossRef]

99. Zhao, L.-Y.; Xu, J.-Y.; Shi, Z.; Englert, N.A.; Zhang, S.-Y. Pregnane X receptor (PXR) deficiency improves high fat diet-induced obesity via induction of fibroblast growth factor 15 (FGF15) expression. Biochem. Pharmacol. 2017, 142, 194-203. [CrossRef] [PubMed]

100. Sookoian, S.; Castaño, G.O.; Burgueño, A.L.; Gianotti, T.F.; Rosselli, M.S.; Pirola, C.J. The nuclear receptor PXR gene variants are associated with liver injury in nonalcoholic fatty liver disease. Pharm. Genom. 2010, 20,1-8. [CrossRef]

101. Maglich, J.M.; Watson, J.; McMillen, P.J.; Goodwin, B.; Willson, T.M.; Moore, J.T. The nuclear receptor CAR is a regulator of thyroid hormone metabolism during caloric restriction. J. Biol. Chem. 2004, 279, 19832-19838. [CrossRef]

102. Ding, X.; Lichti, K.; Kim, I.; Gonzalez, F.J.; Staudinger, J.L. Regulation of constitutive androstane receptor and its target genes by fasting, cAMP, hepatocyte nuclear factor alpha, and the coactivator peroxisome proliferator-activated receptor gamma coactivator-1alpha. J. Biol. Chem. 2006, 281, 26540-26551. [CrossRef]

103. Wieneke, N.; Hirsch-Ernst, K.I.; Kuna, M.; Kersten, S.; Puschel, G.P. PPARalpha-dependent induction of the energy homeostasis-regulating nuclear receptor NR1i3 (CAR) in rat hepatocytes: Potential role in starvation adaptation. FEBS Lett. 2007, 581, 5617-5626. [CrossRef] 
104. Bougarne, N.; Weyers, B.; Desmet, S.J.; Deckers, J.; Ray, D.W.; Staels, B.; De Bosscher, K. Molecular actions of PPARalpha in Lipid metabolism and inflammation. Endocr. Rev. 2018, 39, 760-802. [CrossRef]

105. Saito, K.; Kobayashi, K.; Mizuno, Y.; Fukuchi, Y.; Furihata, T.; Chiba, K. Peroxisome Proliferator-activated Receptor Alpha (PPAR $\alpha$ ) agonists induce Constitutive Androstane Receptor (CAR) and cytochrome P450 2B in rat primary hepatocytes. Drug Metab. Pharmacokinet. 2010, 25, 108-111. [CrossRef]

106. Aouabdi, S.; Gibson, G.; Plant, N. Transcriptional regulation of the PXR gene: Identification and characterization of a functional peroxisome proliferator-activated receptor $\alpha$ binding site within the proximal promoter of pxr. Drug Metab. Dispos. 2005, 34, 138-144. [CrossRef]

107. Buler, M.; Aatsinki, S.-M.; Skoumal, R.; Hakkola, J. Energy sensing factors PGC-1 $\alpha$ and SIRT1 modulate PXR expression and function. Biochem. Pharmacol. 2011, 82, 2008-2015. [CrossRef]

108. Bhutia, Y.; Ogura, J.; Sivaprakasam, S.; Ganapathy, V. Gut microbiome and colon cancer: Role of bacterial metabolites and their molecular targets in the host. Curr. Color. Cancer Rep. 2017, 13, 111-118. [CrossRef]

109. Björkholm, B.; Bok, C.M.; Lundin, A.; Rafter, J.; Hibberd, M.L.; Pettersson, S. Intestinal microbiota regulate xenobiotic metabolism in the liver. PLoS ONE 2009, 4, e6958. [CrossRef]

110. Selwyn, F.P.; Cheng, S.L.; Bammler, T.K.; Prasad, B.; Vrana, M.; Klaassen, C.; Cui, J.Y. Developmental regulation of drug-processing genes in livers of germ-free mice. Toxicol. Sci. 2015, 147, 84-103. [CrossRef]

111. Zemanová, N.; Anzenbacher, P.; Zapletalová, I.; Jourová, L.; Hermanová, P.; Hudcovic, T.; Kozáková, H.; Vodička, M.; Pácha, J.; Anzenbacherová, E. The role of the microbiome and psychosocial stress in the expression and activity of drug metabolizing enzymes in mice. Sci. Rep. 2020, 10, 1-8. [CrossRef] [PubMed]

112. Venu, V.K.P.; Saifeddine, M.; Mihara, K.; Tsai, Y.-C.; Nieves, K.; Alston, L.; Mani, S.; McCoy, K.D.; Hollenberg, M.D.; Hirota, S.A. The pregnane $\mathrm{X}$ receptor and its microbiota-derived ligand indole 3-propionic acid regulate endothelium-dependent vasodilation. Am. J. Physiol. Metab. 2019, 317, E350-E361. [CrossRef]

113. Ranhotra, H.S.; Flannigan, K.L.; Brave, M.; Mukherjee, S.; Lukin, D.J.; Hirota, S.A.; Mani, S. Xenobiotic receptor-mediated regulation of intestinal barrier function and innate immunity. Nucl. Recept. Res. 2016, 3, 3. [CrossRef]

114. Weger, B.D.; Gobet, C.; Yeung, J.; Martin, E.; Jimenez, S.; Betrisey, B.; Foata, F.; Berger, B.; Balvay, A.; Foussier, A.; et al. The mouse microbiome is required for sex-specific diurnal rhythms of gene expression and metabolism. Cell Metab. 2019, 29, 362-382. [CrossRef] [PubMed]

115. Pascussi, J.-M.; Gerbal-Chaloin, S.; Duret, C.; Daujat-Chavanieu, M.; Vilarem, M.-J.; Maurel, P. The tangle of nuclear receptors that controls xenobiotic metabolism and transport: Crosstalk and consequences. Annu. Rev. Pharmacol. Toxicol. 2008, 48, 1-32. [CrossRef]

116. Parviz, F.; Matullo, C.; Garrison, W.D.; Savatski, L.; Adamson, J.W.; Ning, G.; Kaestner, K.H.; Rossi, J.M.; Zaret, K.S.; Duncan, S. Hepatocyte nuclear factor $4 \alpha$ controls the development of a hepatic epithelium and liver morphogenesis. Nat. Genet. 2003, 34, 292-296. [CrossRef]

117. Hayhurst, G.P.; Lee, Y.-H.; Lambert, G.; Ward, J.M.; Gonzalez, F.J. Hepatocyte nuclear factor $4 \alpha$ (nuclear receptor 2A1) is essential for maintenance of hepatic gene expression and lipid homeostasis. Mol. Cell. Biol. 2001, 21, 1393-1403. [CrossRef]

118. Li, J.; Ning, G.; Duncan, S.A. Mammalian hepatocyte differentiation requires the transcription factor HNF- $4 \alpha$. Genome Res. 2000, 14, 464-474.

119. Tirona, R.G.; Lee, W.; Leake, B.F.; Lan, L.-B.; Cline, C.B.; Lamba, V.; Parviz, F.; Duncan, S.A.; Inoue, Y.; Gonzalez, F.J.; et al. The orphan nuclear receptor HNF4 $\alpha$ determines PXR- and CAR-mediated xenobiotic induction of CYP3A. Nat. Med. 2003, 9, 220-224. [CrossRef]

120. Iwazaki, N.; Kobayashi, K.; Morimoto, K.; Hirano, M.; Kawashima, S.; Furihata, T.; Chiba, K. Involvement of hepatocyte nuclear factor 4alpha in transcriptional regulation of the human pregnane $\mathrm{X}$ receptor gene in the human liver. Drug Metab. Pharmacokinet. 2008, 23, 59-66. [CrossRef]

121. Oladimeji, P.; Wright, W.C.; Wu, J.; Chen, T. RNA interference screen identifies NAA10 as a regulator of PXR transcription. Biochem. Pharmacol. 2019, 160, 92-109. [CrossRef] [PubMed]

122. Babeu, J.-P. Hepatocyte nuclear factor 4-alpha involvement in liver and intestinal inflammatory networks. World J. Gastroenterol. 2014, 20, 22-30. [CrossRef] [PubMed]

123. Nakhei, H.; Lingott, A.; Lemm, I.; Ryffel, G.U. An alternative splice variant of the tissue specific transcription factor HNF4 predominates in undifferentiated murine cell types. Nucleic Acids Res. 1998, 26, 497-504. [CrossRef] [PubMed] 
124. Pascussi, J.-M.; Robert, A.; Moreau, A.; Ramos, J.; Bioulac-Sage, P.; Navarro, F.; Blanc, P.; Assenat, E.; Maurel, P.; Vilarem, M.J. Differential regulation of constitutive androstane receptor expression by hepatocyte nuclear factor $4 \alpha$ isoforms. Hepatology 2007, 45, 1146-1153. [CrossRef]

125. Duret, C.; Gerbal-Chaloin, S.; Ramos, J.; Fabre, J.-M.; Jacquet, E.; Navarro, F.; Blanc, P.; Cunha, A.S.; Maurel, P.; Daujat-Chavanieu, M.; et al. Isolation, characterization, and differentiation to hepatocyte-like cells of nonparenchymal epithelial cells from adult human liver. STEM CELLS 2007, 25, 1779-1790. [CrossRef]

126. Pascussi, J.-M.; Gerbal-Chaloin, S.; Fabre, J.-M.; Maurel, P.; Vilarem, M.-J. Dexamethasone enhances constitutive androstane receptor expression in human hepatocytes: Consequences on cytochrome P450 gene regulation. Mol. Pharmacol. 2000, 58, 1441-1450. [CrossRef]

127. Pascussi, J.; Drocourt, L.; Fabre, J.-M.; Maurel, P.; Vilarem, M.-J. Dexamethasone induces pregnane X receptor and retinoid $X$ receptor- $\alpha$ expression in human hepatocytes: Synergistic increase of CYP3A4 induction by pregnane X receptor activators. Mol. Pharmacol. 2000, 58, 361-372. [CrossRef]

128. Duret, C.; Daujat-Chavanieu, M.; Pascussi, J.-M.; Pichard-Garcia, L.; Balaguer, P.; Fabre, J.-M.; Vilarem, M.-J.; Maurel, P.; Gerbal-Chaloin, S. Ketoconazole and miconazole are antagonists of the human glucocorticoid receptor: Consequences on the expression and function of the constitutive androstane receptor and the pregnane X receptor. Mol. Pharmacol. 2006, 70, 329-339. [CrossRef]

129. Cooper, B.W.; Cho, T.M.; Thompson, P.M.; Wallace, A.D. Phthalate induction of CYP3A4 is dependent on glucocorticoid regulation of PXR expression. Toxicol. Sci. 2008, 103, 268-277. [CrossRef]

130. Pascussi, J.-M.; Coniat, M.B.-L.; Maurel, P.; Vilarem, M.-J. Transcriptional analysis of the orphan Nuclear Receptor Constitutive Androstane Receptor (NR1I3) gene promoter: Identification of a distal glucocorticoid response element. Mol. Endocrinol. 2003, 17, 42-55. [CrossRef]

131. Smutny, T.; Dusek, J.; Hyrsova, L.; Nekvindova, J.; Horvatova, A.; Micuda, S.; Gerbal-Chaloin, S.; Pavek, P. The $3^{\prime}$-untranslated region contributes to the pregnane $X$ receptor (PXR) expression down-regulation by PXR ligands and up-regulation by glucocorticoids. Acta Pharm. Sin. B 2019, 10, 136-152. [CrossRef] [PubMed]

132. Huss, J.M.; Kasper, C.B. Two-stage glucocorticoid induction ofCYP3A23through both the glucocorticoid and pregnane X receptors. Mol. Pharmacol. 2000, 58, 48-57. [CrossRef]

133. Bhadhprasit, W.; Sakuma, T.; Hatakeyama, N.; Fuwa, M.; Kitajima, K.; Nemoto, N. Involvement of glucocorticoid receptor and pregnane $\mathrm{X}$ receptor in the regulation of mouse CYP3A44 female-predominant expression by glucocorticoid hormone. Drug Metab. Dispos. 2007, 35, 1880-1885. [CrossRef] [PubMed]

134. Shi, D.; Yang, D.; Yan, B. Dexamethasone transcriptionally increases the expression of the pregnane $\mathrm{X}$ receptor and synergistically enhances pyrethroid esfenvalerate in the induction of cytochrome P450 3A23. Biochem. Pharmacol. 2010, 80, 1274-1283. [CrossRef]

135. Probert, P.M.E.; Chung, G.W.; Cockell, S.J.; Agius, L.; Mosesso, P.; White, S.A.; Oakley, F.; Brown, C.D.A.; Wright, M.C. Utility of B-13 progenitor-derived hepatocytes in hepatotoxicity and genotoxicity studies. Toxicol. Sci. 2013, 137, 350-370. [CrossRef]

136. Chen, Q.; Jia, A.; Snyder, S.A.; Gong, Z.; Lam, S.H. Glucocorticoid activity detected by in vivo zebrafish assay and in vitro glucocorticoid receptor bioassay at environmental relevant concentrations. Chemosphere 2016, 144, 1162-1169. [CrossRef]

137. Haag, M.; Fautrel, A.; Guillouzo, A.; Frossard, N.; Pons, F. Expression of cytochromes P450 3A in mouse lung: Effects of dexamethasone and pregnenolone $16 \alpha$-carbonitrile. Arch. Toxicol. 2002, 77, 145-149. [CrossRef]

138. Khan, A.A.; Chow, E.C.; Van Loenen-Weemaes, A.-M.M.; Porte, R.J.; Pang, K.S.; Groothuis, G.M. Comparison of effects of VDR versus PXR, FXR and GR ligands on the regulation of CYP3A isozymes in rat and human intestine and liver. Eur. J. Pharm. Sci. 2009, 37, 115-125. [CrossRef] [PubMed]

139. Narang, V.S.; Fraga, C.; Kumar, N.; Shen, J.; Throm, S.; Stewart, C.F.; Waters, C.M. Dexamethasone increases expression and activity of multidrug resistance transporters at the rat blood-brain barrier. Am. J. Physiol. Physiol. 2008, 295, C440-C450. [CrossRef]

140. Larigot, L.; Juricek, L.; Dairou, J.; Coumoul, X. AhR signaling pathways and regulatory functions. Biochim. Open 2018, 7, 1-9. [CrossRef]

141. Schraplau, A.; Schewe, B.; Neuschäfer-Rube, F.; Ringel, S.; Neuber, C.; Kleuser, B.; Püschel, G.P. Enhanced thyroid hormone breakdown in hepatocytes by mutual induction of the constitutive and rostane receptor (CAR, NR1I3) and arylhydrocarbon receptor by benzo[a]pyrene and phenobarbital. Toxicology 2015, 328, 21-28. [CrossRef] 
142. Rasmussen, M.K.; Daujat-Chavanieu, M.; Gerbal-Chaloin, S. Activation of the aryl hydrocarbon receptor decreases rifampicin-induced CYP3A4 expression in primary human hepatocytes and HepaRG. Toxicol. Lett. 2017, 277, 1-8. [CrossRef] [PubMed]

143. Modica, S.; Gadaleta, R.M.; Moschetta, A. Deciphering the nuclear bile acid receptor FXR paradigm. Nucl. Recept. Signal. 2010, 8, e005. [CrossRef] [PubMed]

144. Li, T.; Chiang, J.Y.L. Nuclear receptors in bile acid metabolism. Drug Metab. Rev. 2013, 45, 145-155. [CrossRef] [PubMed]

145. Jung, D.; Mangelsdorf, D.J.; Meyer, U.A. Pregnane X receptor is a target of farnesoid X receptor. J. Biol. Chem. 2006, 281, 19081-19091. [CrossRef]

146. Wieneke, N.; Neuschafer-Rube, F.; Bode, L.M.; Kuna, M.; Andres, J.; Carnevali, L.C., Jr.; Hirsch-Ernst, K.I.; Puschel, G.P. Synergistic acceleration of thyroid hormone degradation by phenobarbital and the PPAR alpha agonist WY14643 in rat hepatocytes. Toxicol. Appl. Pharmacol. 2009, 240, 99-107. [CrossRef]

147. Bing, Y.; Zhu, S.; Jiang, K.; Dong, G.; Li, J.; Yang, Z.; Yang, J.; Yue, J. Reduction of thyroid hormones triggers down-regulation of hepatic CYP2B through nuclear receptors CAR and TR in a rat model of acute stroke. Biochem. Pharmacol. 2014, 87, 636-649. [CrossRef]

148. Ooe, H.; Kon, J.; Oshima, H.; Mitaka, T. Thyroid hormone is necessary for expression of constitutive androstane receptor in rat hepatocytes. Drug Metab. Dispos. 2009, 37, 1963-1969. [CrossRef]

149. Wahlang, B.; Prough, R.A.; Falkner, K.C.; Hardesty, J.E.; Song, M.; Clair, H.B.; Clark, B.J.; States, J.C.; Arteel, G.E.; Cave, M.C. Polychlorinated biphenyl-xenobiotic nuclear receptor interactions regulate energy metabolism, behavior, and inflammation in non-alcoholic-steatohepatitis. Toxicol. Sci. 2015, 149, 396-410. [CrossRef]

150. Maglich, J.M.; Stoltz, C.M.; Goodwin, B.; Hawkins-Brown, D.; Moore, J.T.; Kliewer, S.A. Nuclear pregnane x receptor and constitutive androstane receptor regulate overlapping but distinct sets of genes involved in xenobiotic detoxification. Mol. Pharmacol. 2002, 62, 638-646. [CrossRef]

151. Kumari, S.; Saradhi, M.; Rana, M.; Chatterjee, S.; Aumercier, M.; Mukhopadhyay, G.; Tyagi, R.K. Pregnane and Xenobiotic Receptor gene expression in liver cells is modulated by Ets-1 in synchrony with transcription factors Pax5, LEF-1 and c-jun. Exp. Cell Res. 2015, 330, 398-411. [CrossRef] [PubMed]

152. Saradhi, M.; Kumari, S.; Rana, M.; Mukhopadhyay, G.; Tyagi, R.K. Identification and interplay of sequence specific DNA binding proteins involved in regulation of human Pregnane and Xenobiotic Receptor gene. Exp. Cell Res. 2015, 339, 187-196. [CrossRef]

153. Assenat, E.; Gerbal-Chaloin, S.; Larrey, D.; Saric, J.; Fabre, J.M.; Maurel, P.; Vilarem, M.J.; Pascussi, J.M. Interleukin 1beta inhibits CAR-induced expression of hepatic genes involved in drug and bilirubin clearance. Hepatology 2004, 40, 951-960. [CrossRef]

154. Meng, Z.-X.; Wang, L.; Chang, L.; Sun, J.; Bao, J.; Li, Y.; Chen, Y.E.; Lin, J.D. A diet-sensitive BAF60a-mediated pathway links hepatic bile acid metabolism to cholesterol absorption and atherosclerosis. Cell Rep. 2015, 13, 1658-1669. [CrossRef] [PubMed]

155. Ishihara, H.; Yamashita, S.; Amano, R.; Kimura, K.; Hirakawa, K.; Ueda, T.; Murakami, Y.; Tamori, A.; Tanabe, K.; Kawada, N.; et al. Pancreatic cancer cell fraction estimation in a DNA sample. Oncology 2018, 95, 370-379. [CrossRef] [PubMed]

156. Zhang, L.; Miao, X.-J.; Wang, X.; Pan, H.-H.; Li, P.; Ren, H.; Jia, Y.-R.; Lu, C.; Wang, H.-B.; Yuan, L.; et al. Antiproliferation of berberine is mediated by epigenetic modification of constitutive androstane receptor (CAR) metabolic pathway in hepatoma cells. Sci. Rep. 2016, 6, 28116. [CrossRef]

157. Tian, Y. Epigenetic regulation of pregnane X receptor activity. Drug Metab. Rev. 2013, 45, 166-172. [CrossRef] [PubMed]

158. Misawa, A.; Inoue, J.; Sugino, Y.; Hosoi, H.; Sugimoto, T.; Hosoda, F.; Ohki, M.; Imoto, I.; Inazawa, J. Methylation-associated silencing of the nuclear receptor 1I2 gene in advanced-type neuroblastomas, identified by bacterial artificial chromosome array-based methylated CpG island amplification. Cancer Res. 2005, 65, 10233-10242. [CrossRef]

159. Habano, W.; Gamo, T.; Terashima, J.; Sugai, T.; Otsuka, K.; Takahara, T.; Ozawa, S. Involvement of promoter methylation in the regulation of Pregnane X receptor in colon cancer cells. BMC Cancer 2011, 11, 81. [CrossRef]

160. Cabrerizo, R.; Castaño, G.O.; Burgueño, A.L.; Gianotti, T.F.; Ledesma, M.M.G.L.; Flichman, D.; Pirola, C.J.; Sookoian, S. Promoter DNA methylation of farnesoid X receptor and pregnane $\mathrm{X}$ receptor modulates the intrahepatic cholestasis of pregnancy phenotype. PLoS ONE 2014, 9, e87697. [CrossRef] 
161. Takagi, S.; Nakajima, M.; Mohri, T.; Yokoi, T. Post-transcriptional regulation of human pregnane $\mathrm{X}$ receptor by micro-RNA affects the expression of cytochrome P450 3A4. J. Biol. Chem. 2008, 283, 9674-9680. [CrossRef] [PubMed]

162. Lamba, V.; Ghodke-Puranik, Y.; Guan, W.; Tracy, T. microRNA-34a is associated with expression of key hepatic transcription factors and cytochromes P450. Biochem. Biophys. Res. Commun. 2014, 445, 404-411. [CrossRef]

163. Rieger, J.K.; Klein, K.; Winter, S.; Zanger, U.M. Expression variability of absorption, distribution, metabolism, excretion-related MicroRNAs in human liver: Influence of nongenetic factors and association with gene expression. Drug Metab. Dispos. 2013, 41, 1752-1762. [CrossRef]

164. Wei, Z.; Chen, M.; Zhang, Y.; Wang, X.; Jiang, S.; Wang, Y.; Wu, X.; Qin, S.; He, L.; Zhang, L.; et al. No Correlation of hsa-miR-148a with expression of PXR or CYP3A4 in human livers from chinese han population. PLoS ONE 2013, 8, e59141. [CrossRef]

165. Ramamoorthy, A.; Li, L.; Gaedigk, A.; Bradford, L.D.; Benson, E.A.; Flockhart, D.A.; Skaar, T.C. In silico and in vitro identification of microRNAs that regulate hepatic nuclear factor $4 \alpha$ expression. Drug Metab. Dispos. 2012, 40, 726-733. [CrossRef]

166. Sharma, D.; Turkistani, A.A.; Chang, T.K.; Hu, C.; Xu, Z.; Chang, T.K.H. Negative regulation of human pregnane $X$ receptor by MicroRNA-18a-5p: Evidence for suppression of MicroRNA-18a-5p expression by rifampin and rilpivirine. Mol. Pharmacol. 2017, 92, 48-56. [CrossRef]

167. Rao, Z.-Z.; Zhang, X.-W.; Ding, Y.-L.; Yang, M.-Y. miR-148a-mediated estrogen-induced cholestasis in intrahepatic cholestasis of pregnancy: Role of PXR/MRP. PLoS ONE 2017, 12, e0178702. [CrossRef]

168. Reuter, T.; Herold-Mende, C.; Dyckhoff, G.; Rigalli, J.P.; Weiss, J. Functional role of miR-148a in oropharyngeal cancer: Influence on pregnane $X$ receptor and P-glycoprotein expression. J. Recept. Signal Transduct. 2019, 39, 451-459. [CrossRef] [PubMed]

169. Li, M.; Yang, Y.; He, Z.-X.; Zhou, Z.-W.; Yang, T.; Guo, P.; Zhang, X.; Zhou, S.-F. MicroRNA-561 promotes acetaminophen-induced hepatotoxicity in HepG2 cells and primary human hepatocytes through downregulation of the nuclear receptor corepressor dosage-sensitive sex-reversal adrenal hypoplasia congenital critical region on the X chromosome, gene 1 (DAX-1). Drug Metab. Dispos. 2013, 42, 44-61. [CrossRef]

170. Takwi, A.; Wang, Y.-M.; Wu, J.; Michaelis, M.; Cinatl, J.; Chen, T. miR-137 regulates the constitutive androstane receptor and modulates doxorubicin sensitivity in parental and doxorubicin-resistant neuroblastoma cells. Oncogene 2014, 33, 3717-3729. [CrossRef] [PubMed]

171. Vachirayonstien, T.; Yan, B. MicroRNA-30c-1-3p is a silencer of the pregnane $X$ receptor by targeting the $3^{\prime}$-untranslated region and alters the expression of its target gene cytochrome P450 3A4. Biochim. Biophys. Acta (BBA) Bioenerg. 2016, 1859, 1238-1244. [CrossRef]

172. Li, J.; Zhao, J.; Wang, H.; Li, X.; Liu, A.; Qin, Q.; Li, B. MicroRNA-140-3p enhances the sensitivity of hepatocellular carcinoma cells to sorafenib by targeting pregnenolone $\mathrm{X}$ receptor. OncoTargets Ther. 2018, 11, 5885-5894. [CrossRef]

173. Deng, Y.; Wei, Z.; Huang, M.; Xu, G.; Wei, W.; Peng, B.; Nong, S.; Qin, H. Long non-coding RNA F11-AS1 inhibits HBV-related hepatocellular carcinoma progression by regulating NR1I3 via binding to microRNA-211-5p. J. Cell. Mol. Med. 2019, 24, 1848-1865. [CrossRef]

174. Li, D.; Wu, L.; Knox, B.; Chen, S.; Tolleson, W.H.; Liu, F.; Yu, D.; Guo, L.; Tong, W.; Ning, B. Long noncoding RNA LINC00844-mediated molecular network regulates expression of drug metabolizing enzymes and nuclear receptors in human liver cells. Arch. Toxicol. 2020, 94, 1637-1653. [CrossRef]

175. Qi, X.; Zhang, D.-H.; Wu, N.; Xiao, J.-H.; Wang, X.; Ma, W. ceRNA in cancer: Possible functions and clinical implications. J. Med. Genet. 2015, 52, 710-718. [CrossRef]

176. Wang, Y.; Yan, L.; Liu, J.; Chen, S.; Liu, G.; Nie, Y.; Wang, P.; Yang, W.; Chen, L.; Zhong, X.; et al. The HNF1 $\alpha$-regulated LncRNA HNF1 $\alpha$-AS1 Is involved in the regulation of cytochrome P450 expression in human liver tissues and Huh7 cells. J. Pharmacol. Exp. Ther. 2019, 368, 353-362. [CrossRef] [PubMed]

177. Nakano, M.; Fukami, T.; Nakajima, M. Adenosine deaminases acting on RNA downregulate the expression of constitutive androstane receptor in the human liver-derived cells by attenuating splicing. J. Pharmacol. Exp. Ther. 2019, 370, 408-415. [CrossRef]

178. Masuyama, H.; Inoshita, H.; Hiramatsu, Y.; Kudo, T. Ligands have various potential effects on the degradation of pregnane $X$ receptor by proteasome. Endocrinology 2002, 143, 55-61. [CrossRef] 
179. Rana, R.; Coulter, S.; Kinyamu, H.; Goldstein, J.A. RBCK1, an E3 ubiquitin ligase, interacts with and ubiquinates the human pregnane X receptor. Drug Metab. Dispos. 2012, 41, 398-405. [CrossRef]

180. Ong, S.S.; Goktug, A.N.; Elias, A.; Wu, J.; Saunders, D.N.; Chen, T. Stability of the human pregnane X receptor is regulated by E3 ligase UBR5 and serine/threonine kinase DYRK. Biochem. J. 2014, 459, 193-203. [CrossRef]

181. Pettersson, F.; Hanna, N.; Lagodich, M.; Dupéré-Richer, D.; Couture, M.-C.; Choi, C.; Miller, W.H. Rexinoids modulate steroid and xenobiotic receptor activity by increasing its protein turnover in a calpain-dependent manner. J. Biol. Chem. 2008, 283, 21945-21952. [CrossRef]

182. Chen, T.; Laurenzana, E.M.; Coslo, D.M.; Chen, F.; Omiecinski, C.J. Proteasomal interaction as a critical activity modulator of the human constitutive androstane receptor. Biochem. J. 2014, 458, 95-107. [CrossRef]

183. Gerbal-Chaloin, S.; Iankova, I.; Maurel, P.; Daujat-Chavanieu, M. Nuclear receptors in the cross-talk of drug metabolism and inflammation. Drug Metab. Rev. 2013, 45, 122-144. [CrossRef]

184. Beigneux, A.P.; Moser, A.H.; Shigenaga, J.K.; Grunfeld, C.; Feingold, K.R. Reduction in cytochrome P-450 enzyme expression is associated with repression of CAR (constitutive androstane receptor) and PXR (pregnane $X$ receptor) in mouse liver during the acute phase response. Biochem. Biophys. Res. Commun. 2002, 293, 145-149. [CrossRef]

185. Abualsunun, W.A.; Piquette-Miller, M. Involvement of nuclear factor $\kappa B$, not pregnane $X$ receptor, in inflammation-mediated regulation of hepatic transporters. Drug Metab. Dispos. 2017, 45, 1077-1083. [CrossRef]

186. Xu, D.-X.; Wei, W.; Sun, M.-F.; Wu, C.-Y.; Wang, J.-P.; Wei, L.-Z.; Zhou, C.-F. Kupffer cells and reactive oxygen species partially mediate lipopolysaccharide-induced downregulation of nuclear receptor pregnane $x$ receptor and its target gene CYP3a in mouse liver. Free. Radic. Biol. Med. 2004, 37, 10-22. [CrossRef]

187. Xu, D.-X.; Chen, Y.-H.; Wang, J.-P.; Sun, M.-F.; Wang, H.; Wei, L.-Z.; Wei, W. Perinatal lipopolysaccharide exposure downregulates pregnane $\mathrm{X}$ receptor and Cyp3a11 expression in fetal mouse liver. Toxicol. Sci. 2005, 87, 38-45. [CrossRef]

188. Xu, D.-X.; Wei, W.; Sun, M.-F.; Wei, L.-Z.; Wang, J.-P. Melatonin attenuates lipopolysaccharide-induced down-regulation of pregnane $X$ receptor and its target gene CYP3A in mouse liver. J. Pineal Res. 2005, 38, 27-34. [CrossRef]

189. Ghose, R.; Guo, T.; Vallejo, J.G.; Gandhi, A. Differential role of Toll-interleukin 1 receptor domain-containing adaptor protein in Toll-like receptor 2-mediated regulation of gene expression of hepatic cytokines and drug-metabolizing enzymes. Drug Metab. Dispos. 2011, 39, 874-881. [CrossRef]

190. Pascussi, J.-M.; Gerbal-Chaloin, S.; Pichard-Garcia, L.; Daujat, M.; Fabre, J.-M.; Maurel, P.; Vilarem, M.-J. Interleukin-6 negatively regulates the expression of pregnane $x$ receptor and constitutively activated receptor in primary human hepatocytes. Biochem. Biophys. Res. Commun. 2000, 274, 707-713. [CrossRef]

191. Ogura, J.; Terada, Y.; Tsujimoto, T.; Koizumi, T.; Kuwayama, K.; Maruyama, H.; Fujikawa, A.; Takaya, A.; Kobayashi, M.; Itagaki, S.; et al. The decrease in farnesoid $X$ receptor, pregnane $X$ receptor and constitutive androstane receptor in the liver after intestinal ischemia-reperfusion. J. Pharm. Pharm. Sci. 2012, 15, 616-631. [CrossRef]

192. Tanner, N.; Kubik, L.; Luckert, C.; Thomas, M.; Hofmann, U.; Zanger, U.M.; Bohmert, L.; Lampen, A.; Braeuning, A. Regulation of drug metabolism by the interplay of inflammatory signaling, steatosis, and xeno-sensing receptors in HepaRG cells. Drug Metab. Dispos. 2018, 46, 326-335. [CrossRef] [PubMed]

193. Ning, R.; Zhan, Y.; He, S.; Hu, J.; Zhu, Z.; Hu, G.; Yan, B.; Yang, J.; Liu, W. Interleukin-6 induces DEC1, promotes DEC1 interaction with RXRalpha and suppresses the expression of PXR, CAR and their target genes. Front. Pharmacol. 2017, 8, 866. [CrossRef]

194. Teng, S.; Piquette-Miller, M. The involvement of the pregnane $X$ receptor in hepatic gene regulation during inflammation in mice. J. Pharmacol. Exp. Ther. 2004, 312, 841-848. [CrossRef]

195. Rasmussen, M.K.; Bertholdt, L.; Gudiksen, A.; Pilegaard, H.; Knudsen, J.G. Impact of fasting followed by short-term exposure to interleukin-6 on cytochrome P450 mRNA in mice. Toxicol. Lett. 2018, 282, 93-99. [CrossRef]

196. Xie, L.; He, Y.; Zhou, X.; Li, X.; Jin, X.; Wang, X.; Shi, D. Porcine interleukin-6 enhances the expression of CYP2C33 through a constitutive androstane receptor/retinoid $\mathrm{X}$ receptor-mediated pathway. Xenobiotica 2018, 49, 257-264. [CrossRef] 
197. Geier, A.; Dietrich, C.G.; Voigt, S.; Ananthanarayanan, M.; Lammert, F.; Schmitz, A.; Trauner, M.; Wasmuth, H.E.; Boraschi, D.; Balasubramaniyan, N.; et al. Cytokine-dependent regulation of hepatic organic anion transporter gene transactivators in mouse liver. Am. J. Physiol. Liver Physiol. 2005, 289, G831-G841. [CrossRef]

198. Langmann, T.; Moehle, C.; Mauerer, R.; Scharl, M.; Liebisch, G.; Zahn, A.; Stremmel, W.; Schmitz, G. Loss of detoxification in inflammatory bowel disease: Dysregulation of pregnane $\mathrm{X}$ receptor target genes. Gastroenterology 2004, 127, 26-40. [CrossRef]

199. Bossche, L.V.D.; Borsboom, D.; Devriese, S.; Van Welden, S.; Holvoet, T.; Devisscher, L.; Hindryckx, P.; De Vos, M.; Laukens, D. Tauroursodeoxycholic acid protects bile acid homeostasis under inflammatory conditions and dampens Crohn's disease-like ileitis. Lab. Investig. 2017, 97, 519-529. [CrossRef]

200. Deuring, J.J.; Li, M.; Cao, W.; Chen, S.; Wang, W.; de Haar, C.; van der Woude, C.J.; Peppelenbosch, M. Pregnane $\mathrm{X}$ receptor activation constrains mucosal NF-kappaB activity in active inflammatory bowel disease. PLOS ONE 2019, 14, e0221924. [CrossRef]

201. Kusunoki, Y.; Ikarashi, N.; Hayakawa, Y.; Ishii, M.; Kon, R.; Ochiai, W.; Machida, Y.; Sugiyama, K. Hepatic early inflammation induces downregulation of hepatic cytochrome $\mathrm{P} 450$ expression and metabolic activity in the dextran sulfate sodium-induced murine colitis. Eur. J. Pharm. Sci. 2014, 54, 17-27. [CrossRef]

202. Kusunoki, Y.; Ikarashi, N.; Matsuda, S.; Matsukawa, Y.; Kitaoka, S.; Kon, R.; Tajima, M.; Wakui, N.; Ochiai, W.; Machida, Y.; et al. Expression of hepatic cytochrome P450 in a mouse model of ulcerative colitis changes with pathological conditions. J. Gastroenterol. Hepatol. 2015, 30, 1618-1626. [CrossRef] [PubMed]

203. Xu, D.-X.; Wang, J.-P.; Sun, M.-F.; Chen, Y.-H.; Wei, W. Lipopolysaccharide downregulates the expressions of intestinal pregnane $X$ receptor and cytochrome P450 3a11. Eur. J. Pharmacol. 2006, 536, 162-170. [CrossRef]

204. Chen, Y.-H.; Wang, J.-P.; Wang, H.; Sun, M.-F.; Wei, L.-Z.; Wei, W.; Xu, D.-X. Lipopolysaccharide treatment downregulates the expression of the pregnane $X$ receptor, cyp3a11 and mdr1a genes in mouse placenta. Toxicology 2005, 211, 242-252. [CrossRef] [PubMed]

205. Yoshinari, K.; Takagi, S.; Sugatani, J.; Miwa, M. Changes in the expression of cytochromes P450 and nuclear receptors in the liver of genetically diabetic db/db mice. Biol. Pharm. Bull. 2006, 29, 1634-1638. [CrossRef]

206. Zhang, H.; Zhao, T.; Li, Z.; Yan, M.; Zhao, H.; Zhu, B.; Li, P. Transcriptional profile of kidney from type 2 diabetic db/db mice. J. Diabetes Res. 2017, 2017, 1-12. [CrossRef] [PubMed]

207. Lam, J.L.; Jiang, Y.; Zhang, T.; Zhang, E.Y.; Smith, B.J. Expression and functional analysis of hepatic cytochromes P450, nuclear receptors, and membrane transporters in 10- and 25-week-old db/db mice. Drug Metab. Dispos. 2010, 38, 2252-2258. [CrossRef]

208. Xiong, H.; Yoshinari, K.; Brouwer, K.L.; Negishi, M. Role of constitutive androstane receptor in the in vivo induction of Mrp3 and CYP2B1/2 by phenobarbital. Drug Metab. Dispos. 2002, 30, 918-923. [CrossRef]

209. Zhang, L.; Xu, P.; Cheng, Y.; Wang, P.; Ma, X.; Liu, M.; Wang, X.; Xu, F. Diet-induced obese alters the expression and function of hepatic drug-metabolizing enzymes and transporters in rats. Biochem. Pharmacol. 2019, 164, 368-376. [CrossRef]

210. Ghoneim, R.H.; Sock, E.T.N.; Lavoie, J.-M.; Piquette-Miller, M. Effect of a high-fat diet on the hepatic expression of nuclear receptors and their target genes: Relevance to drug disposition. Br. J. Nutr. 2015, 113, 507-516. [CrossRef]

211. Wang, P.; Shao, X.; Bao, Y.; Zhu, J.; Chen, L.; Zhang, L.; Ma, X.; Zhong, X.-B. Impact of obese levels on the hepatic expression of nuclear receptors and drug-metabolizing enzymes in adult and offspring mice. Acta Pharm. Sin. B 2020, 10, 171-185. [CrossRef] [PubMed]

212. Zhang, F.; Duan, Y.; Wei, Y.; Zhang, J.; Ma, X.; Tian, H.; Wang, X.; Saad, A.A.A.; Li, B.; Wu, X. The inhibition of hepatic Pxr-Oatp2 pathway mediating decreased hepatic uptake of rosuvastatin in rats with high-fat diet-induced obesity. Life Sci. 2020, 257, 118079. [CrossRef] [PubMed]

213. Li, X.; Wang, Z.; Klaunig, J.E. Modulation of xenobiotic nuclear receptors in high-fat diet induced non-alcoholic fatty liver disease. Toxicology 2018, 410, 199-213. [CrossRef]

214. Ghose, R.; Omoluabi, O.; Gandhi, A.; Shah, P.; Strohacker, K.; Carpenter, K.C.; McFarlin, B.; Guo, T. Role of high-fat diet in regulation of gene expression of drug metabolizing enzymes and transporters. Life Sci. 2011, 89, 57-64. [CrossRef]

215. Kudo, T.; Shimada, T.; Toda, T.; Igeta, S.; Suzuki, W.; Ikarashi, N.; Ochiai, W.; Ito, K.; Aburada, M.; Sugiyama, K. Altered expression of CYP in TSOD mice: A model of type 2 diabetes and obesity. Xenobiotica 2009, 39, 889-902. [CrossRef] 
216. Bushkofsky, J.R.; Maguire, M.; Larsen, M.C.; Fong, Y.H.; Jefcoate, C.R. Cyp1b1 affects external control of mouse hepatocytes, fatty acid homeostasis and signaling involving HNF4alpha and PPARalpha. Arch. Biochem. Biophys. 2016, 597, 30-47. [CrossRef]

217. Yao, H.; Gu, J.; Shan, Y.; Wang, Y.; Chen, X.; Sun, D.; Guo, Y. Type 2 diabetes mellitus decreases systemic exposure of clopidogrel active metabolite through upregulation of P-glycoprotein in rats. Biochem. Pharmacol. 2020, 180, 114142. [CrossRef]

218. Watanabe, A.; Marumo, T.; Kawarazaki, W.; Nishimoto, M.; Ayuzawa, N.; Ueda, K.; Hirohama, D.; Tanaka, T.; Yagi, S.; Ota, S.; et al. Aberrant DNA methylation of pregnane $\mathrm{X}$ receptor underlies metabolic gene alterations in the diabetic kidney. Am. J. Physiol. Physiol. 2018, 314, F551-F560. [CrossRef]

219. Cusi, K. Nonalcoholic fatty liver disease in type 2 diabetes mellitus. Curr. Opin. Endocrinol. Diabetes Obes. 2009, 16, 141-149. [CrossRef]

220. Oladimeji, P.; Lin, W.; Brewer, C.T.; Chen, T. Glucose-dependent regulation of pregnane $X$ receptor is modulated by AMP-activated protein kinase. Sci. Rep. 2017, 7, 46751. [CrossRef]

221. Xiong, J.; Shang, W.; Wu, L.; Chen, R.; Liu, W.; Ning, R.; Hu, G.; Yang, J. Glucose dominates the regulation of carboxylesterases induced by lipopolysaccharide or interleukin-6 in primary mouse hepatocytes. Life Sci. 2014, 112, 41-48. [CrossRef]

222. Davidson, M.D.; Ballinger, K.R.; Khetani, S.R. Long-term exposure to abnormal glucose levels alters drug metabolism pathways and insulin sensitivity in primary human hepatocytes. Sci. Rep. 2016, 6, 28178. [CrossRef] [PubMed]

223. Yang, X.; Zhang, X.; Liu, Y.; Xi, T.; Xiong, J. Insulin transcriptionally down-regulates carboxylesterases through pregnane $X$ receptor in an Akt-dependent manner. Toxicology 2019, 422, 60-68. [CrossRef]

224. Shan, E.; Zhu, Z.; He, S.; Chu, D.; Ge, D.; Zhan, Y.; Liu, W.; Yang, J.; Xiong, J. Involvement of pregnane $\mathrm{X}$ receptor in the suppression of carboxylesterases by metformin in vivo and in vitro, mediated by the activation of AMPK and JNK signaling pathway. Eur. J. Pharm. Sci. 2017, 102, 14-23. [CrossRef] [PubMed]

225. Luo, W.; Xin, Y.; Zhao, X.; Zhang, F.; Liu, C.; Fan, H.; Xi, T.; Xiong, J. Suppression of carboxylesterases by imatinib mediated by the down-regulation of pregnane $X$ receptor. Br. J. Pharmacol. 2017, 174, 700-717. [CrossRef] [PubMed]

226. Zhang, Y.; Li, C.; Sun, X.; Kuang, X.; Ruan, X.-C. High glucose decreases expression and activity of p-glycoprotein in cultured human retinal pigment epithelium possibly through iNOS induction. PLoS ONE 2012, 7, e31631. [CrossRef] [PubMed]

227. Rowe, I.A. Lessons from epidemiology: The burden of liver disease. Dig. Dis. 2017, 35, 304-309. [CrossRef]

228. Jungst, C.; Lammert, F. Cholestatic liver disease. Dig Dis. 2013, 31, 152-154. [CrossRef]

229. Kurzawski, M.; Dziedziejko, V.; Post, M.; Wójcicki, M.; Urasińska, E.; Miętkiewski, J.; Drozdzik, M. Expression of genes involved in xenobiotic metabolism and transport in end-stage liver disease: Up-regulation of ABCC4 and CYP1B. Pharmacol. Rep. 2012, 64, 927-939. [CrossRef]

230. Congiu, M.; Mashford, M.L.; Slavin, J.L.; Desmond, P.V. Coordinate regulation of metabolic enzymes and transporters by nuclear transcription factors in human liver disease. J. Gastroenterol. Hepatol. 2009, 24, 1038-1044. [CrossRef]

231. Hanada, K.; Nakai, K.; Tanaka, H.; Suzuki, F.; Kumada, H.; Ohno, Y.; Ozawa, S.; Ogata, H. Effect of nuclear receptor downregulation on hepatic expression of cytochrome $\mathrm{P} 450$ and transporters in chronic hepatitis $\mathrm{C}$ in association with fibrosis development. Drug Metab. Pharmacokinet. 2011, 27, 301-306. [CrossRef] [PubMed]

232. More, V.R.; Cheng, Q.; Donepudi, A.C.; Buckley, D.B.; Lu, Z.J.; Cherrington, N.J.; Slitt, A.L. Alcohol cirrhosis alters nuclear receptor and drug transporter expression in human liver. Drug Metab. Dispos. 2013, 41, 1148-1155. [CrossRef]

233. Elbel, E.E.; LaVine, J.E.; Downes, M.; Van Natta, M.; Yu, R.; Schwimmer, J.B.; Behling, C.; Brunt, E.M.; Tonascia, J.; Evans, R. Hepatic nuclear receptor expression associates with features of histology in pediatric nonalcoholic fatty liver disease. Hepatol. Commun. 2018, 2, 1213-1226. [CrossRef]

234. Angulo, P.; Kleiner, D.E.; Dam-Larsen, S.; Adams, L.A.; Björnsson, E.S.; Charatcharoenwitthaya, P.; Mills, P.R.; Keach, J.C.; Lafferty, H.D.; Stahler, A.; et al. Liver fibrosis, but no other histologic features, is associated with long-term outcomes of patients with nonalcoholic fatty liver disease. Gastroenterology 2015, 149, 389-397. [CrossRef] 
235. Tutau, F.; Rodríguez, C.; Puche, J.E.; Juanarena, N.; Monreal, I.; Garcia-Fernandez, M.I.; Clavijo, E.; Castilla, A.; Castilla-Cortázar, I. Enhanced actions of insulin-like growth factor-I and interferon- $\alpha$ co-administration in experimental cirrhosis. Liver Int. 2009, 29, 37-46. [CrossRef] [PubMed]

236. Mohandas, S.; Vairappan, B. Ginkgolide-A attenuates bacterial translocation through activating PXR and improving antimicrobial peptide Reg 3A in experimental cirrhosis. Life Sci. 2020, 257, 118111. [CrossRef]

237. Mohandas, S.; Vairappan, B. Pregnane $X$ receptor activation by its natural ligand Ginkgolide-A improves tight junction proteins expression and attenuates bacterial translocation in cirrhosis. Chem. Interact. 2020, 315, 108891. [CrossRef]

238. Xie, Y.; Hao, H.-P.; Wang, H.; Wang, Z.-X.; Wang, G.-J. Reversing effects of silybin on TAA-induced hepatic CYP3A dysfunction through PXR regulation. Chin. J. Nat. Med. 2013, 11, 645-652. [CrossRef]

239. Naito, H.; Jia, X.; Yetti, H.; Yanagiba, Y.; Tamada, H.; Kitamori, K.; Hayashi, Y.; Wang, D.; Kato, M.; Ishii, A.; et al. Importance of detoxifying enzymes in differentiating fibrotic development between SHRSP5/Dmcr and SHRSP rats. Environ. Health Prev. Med. 2016, 21, 368-381. [CrossRef]

240. Yetti, H.; Naito, H.; Yuan, Y.; Jia, X.; Hayashi, Y.; Tamada, H.; Kitamori, K.; Ikeda, K.; Yamori, Y.; Nakajima, T. Bile acid detoxifying enzymes limit susceptibility to liver fibrosis in female SHRSP5/Dmcr rats fed with a high-fat-cholesterol diet. PLOS ONE 2018, 13, e0192863. [CrossRef]

241. Avouac, J. Mouse model of experimental dermal fibrosis: The bleomycin-induced dermal fibrosis. Adv. Struct. Saf. Stud. 2014, 1142, 91-98. [CrossRef]

242. Wunsch, E.; Klak, M.; Wasik, U.; Milkiewicz, M.; Blatkiewicz, M.; Urasinska, E.; Barbier, O.; Bielicki, D.; Bogdanos, D.P.; Elias, E.; et al. Liver expression of sulphotransferase 2A1 enzyme is impaired in patients with primary sclerosing cholangitis: Lack of the response to enhanced expression of PXR. J. Immunol. Res. 2015, 2015, 1-8. [CrossRef]

243. Zollner, G.; Wagner, M.; Fickert, P.; Silbert, D.; Gumhold, J.; Zatloukal, K.; Denk, H.; Trauner, M. Expression of bile acid synthesis and detoxification enzymes and the alternative bile acid efflux pump MRP4 in patients with primary biliary cirrhosis. Liver Int. 2007, 27, 920-929. [CrossRef] [PubMed]

244. Chai, J.; Luo, D.; Wu, X.; Wang, H.; He, Y.; Li, Q.; Zhang, Y.; Chen, L.; Peng, Z.-H.; Xiao, T.; et al. Changes of organic anion transporter MRP4 and related nuclear receptors in human obstructive cholestasis. J. Gastrointest. Surg. 2011, 15, 996-1004. [CrossRef] [PubMed]

245. Chai, J.; Feng, X.; Zhang, L.; Chen, S.; Cheng, Y.; He, X.; Yang, Y.; He, Y.; Wang, H.; Wang, R.; et al. Hepatic expression of detoxification enzymes is decreased in human obstructive cholestasis due to gallstone biliary obstruction. PLoS ONE 2015, 10, e0120055. [CrossRef] [PubMed]

246. Chen, H.-L.; Liu, Y.-J.; Chen, H.-L.; Wu, S.-H.; Ni, Y.-H.; Ho, M.-C.; Lai, H.-S.; Hsu, W.-M.; Chang, M.-H.; Tseng, H.-C.; et al. Expression of hepatocyte transporters and nuclear receptors in children with early and late-stage biliary atresia. Pediatr. Res. 2008, 63, 667-673. [CrossRef]

247. Honda, A.; Ikegami, T.; Nakamuta, M.; Miyazaki, T.; Iwamoto, J.; Hirayama, T.; Saito, Y.; Takikawa, H.; Imawari, M.; Matsuzaki, Y. Anticholestatic effects of bezafibrate in patients with primary biliary cirrhosis treated with ursodeoxycholic acid. Hepatology 2013, 57, 1931-1941. [CrossRef]

248. Gabbia, D.; Pozzo, L.; Zigiotto, G.; Roverso, M.; Sacchi, D.; Pozza, A.D.; Carrara, M.; Bogialli, S.; Floreani, A.; Guido, M.; et al. Dexamethasone counteracts hepatic inflammation and oxidative stress in cholestatic rats via CAR activation. PLoS ONE 2018, 13, e0204336. [CrossRef]

249. Li, T.; Xu, L.; Zheng, R.; Wang, X.; Li, L.; Ji, H.; Hu, Q. Picroside II protects against cholestatic liver injury possibly through activation of farnesoid $X$ receptor. Phytomedicine 2020, 68, 153153. [CrossRef]

250. Teng, S.; Piquette-Miller, M. Hepatoprotective role of PXR activation and MRP3 in cholic acid-induced cholestasis. Br. J. Pharmacol. 2007, 151, 367-376. [CrossRef]

251. Gabbia, D.; Pozza, A.D.; Albertoni, L.; Lazzari, R.; Zigiotto, G.; Carrara, M.; Baldo, V.; Baldovin, T.; Floreani, A.; De Martin, S. Pregnane $X$ receptor and constitutive androstane receptor modulate differently CYP3A-mediated metabolism in early- and late-stage cholestasis. World J. Gastroenterol. 2017, 23, 7519-7530. [CrossRef]

252. Gupta, D.; Venkatesh, M.; Wang, H.; Kim, S.; Sinz, M.; Goldberg, G.L.; Whitney, K.; Longley, C.; Mani, S. Expanding the roles for pregnane $\mathrm{X}$ receptor in cancer: Proliferation and drug resistance in ovarian cancer. Clin. Cancer Res. 2008, 14, 5332-5340. [CrossRef] 
253. Dong, Y.; Wang, Z.; Xie, G.; Li, C.; Zuo, W.-W.; Meng, G.; Xu, C.-P.; Li, J. Pregnane X receptor is associated with unfavorable survival and induces chemotherapeutic resistance by transcriptional activating multidrug resistance-related protein 3 in colorectal cancer. Mol. Cancer 2017, 16, 71. [CrossRef] [PubMed]

254. Van de Winkel, A.; Menke, V.; Capello, A.; Moons, L.M.; Pot, R.G.; van Dekken, H.; Siersema, P.D.; Kusters, J.G.; van der Laan, L.J.; Kuipers, E.J. Expression, localization and polymorphisms of the nuclear receptor PXR in Barrett's esophagus and esophageal adenocarcinoma. BMC Gastroenterol. 2011, 11, 108. [CrossRef]

255. Dotzlaw, H.; Leygue, E.; Watson, P.; Murphy, L.C. The human orphan receptor PXR messenger RNA is expressed in both normal and neoplastic breast tissue. Clin. Cancer Res. 1999, 5, 2103-2107. [PubMed]

256. Chen, Y.; Tang, Y.; Wang, M.-T.; Zeng, S.; Nie, D. Human pregnane X receptor and resistance to chemotherapy in prostate cancer. Cancer Res. 2007, 67, 10361-10367. [CrossRef] [PubMed]

257. Masuyama, H.; Hiramatsu, Y.; Kodama, J.-I.; Kudo, T. Expression and potential roles of pregnane X receptor in endometrial cancer. J. Clin. Endocrinol. Metab. 2003, 88, 4446-4454. [CrossRef] [PubMed]

258. Planque, C.; Rajabi, F.; Grillet, F.; Finetti, P.; Bertucci, F.; Gironella, M.; Lozano, J.J.; Beucher, B.; Giraud, J.; Garambois, V.; et al. Pregnane X-receptor promotes stem cell-mediated colon cancer relapse. Oncotarget 2016, 7, 56558-56573. [CrossRef] [PubMed]

259. Qiao, E.; Ji, M.; Wu, J.; Ma, R.; Zhang, X.; He, Y.; Zha, Q.; Song, X.; Zhu, L.-W.; Tang, J. Expression of the PXR gene in various types of cancer and drug resistance. Oncol. Lett. 2013, 5, 1093-1100. [CrossRef]

260. Bhagyaraj, E.; Ahuja, N.; Kumar, S.; Tiwari, D.; Gupta, S.; Nanduri, R.; Gupta, P. TGF-beta induced chemoresistance in liver cancer is modulated by xenobiotic nuclear receptor PXR. Cell Cycle 2019, 18, 3589-3602. [CrossRef]

261. Kotiya, D.; Jaiswal, B.; Ghose, S.; Kaul, R.; Datta, K.; Tyagi, R.K. Role of PXR in hepatic cancer: Its influences on liver detoxification capacity and cancer progression. PLoS ONE 2016, 11, e0164087. [CrossRef]

262. Haines, C.; Elcombe, B.M.; Chatham, L.R.; Vardy, A.; Higgins, L.G.; Elcombe, C.R.; Lake, B.G. Comparison of the effects of sodium phenobarbital in wild type and humanized constitutive androstane receptor (CAR)/pregnane $X$ receptor (PXR) mice and in cultured mouse, rat and human hepatocytes. Toxicology 2018, 396-397, 23-32. [CrossRef]

263. Chen, Y.; Tang, Y.; Guo, C.; Wang, J.; Boral, D.; Nie, D. Nuclear receptors in the multidrug resistance through the regulation of drug-metabolizing enzymes and drug transporters. Biochem. Pharmacol. 2012, 83, 1112-1126. [CrossRef]

264. Robbins, D.; Chen, T. Tissue-specific regulation of pregnane $X$ receptor in cancer development and therapy. Cell Biosci. 2014, 4, 17. [CrossRef] [PubMed]

265. Chakraborty, S.; Kanakasabai, S.; Bright, J.J. Constitutive androstane receptor agonist CITCO inhibits growth and expansion of brain tumour stem cells. Br. J. Cancer 2011, 104, 448-459. [CrossRef] [PubMed]

266. Fukumasu, H.; Cordeiro, Y.; Rochetti, A.; Barra, C.; Sámora, T.; Strefezzi, R.; Dagli, M.L.Z. Expression of NR1I3 in mouse lung tumors induced by the tobacco-specific nitrosamine 4-(methylnitrosamino)-4-(3-pyridyl)-1-butanone. Braz. J. Med. Biol. Res. 2015, 48, 240-244. [CrossRef]

267. Nagata, T.; Takahashi, Y.; Ishii, Y.; Asai, S.; Nishida, Y.; Murata, A.; Koshinaga, T.; Fukuzawa, M.; Hamazaki, M.; Asami, K.; et al. Transcriptional profiling in hepatoblastomas using high-density oligonucleotide DNA array. Cancer Genet. Cytogenet. 2003, 145, 152-160. [CrossRef]

268. Tang, H.Q.; Xu, M.; Rong, Q.; Jin, R.W.; Liu, Q.J.; Li, Y.L. The effect of ZnO nanoparticles on liver function in rats. Int. J. Nanomed. 2016, 11, 4275-4285.

269. Tang, H.; Xu, M.; Shi, F.; Ye, G.; Lv, C.; Luo, J.; Zhao, L.; Li, Y. Effects and mechanism of nano-copper exposure on hepatic cytochrome P450 enzymes in rats. Int. J. Mol. Sci. 2018, 19, 2140. [CrossRef]

270. Wang, Y.; Tang, H.; Xu, M.; Luo, J.; Zhao, L.; Shi, F.; Ye, G.; Lv, C.; Li, Y. Effect of copper nanoparticles on brain cytochrome P450 enzymes in rats. Mol. Med. Rep. 2019, 20, 771-778. [CrossRef] [PubMed]

271. Tian, J.; Hu, J.; Liu, G.; Yin, H.; Chen, M.; Miao, P.; Bai, P.; Yin, J. Corrigendum to "Altered gene expression of $\mathrm{ABC}$ transporters, nuclear receptors and oxidative stress signaling in zebrafish embryos exposed to CdTe quantum dots". Environ. Pollut. 2019, 245, 1136. [CrossRef]

272. Zenata, O.; Vrzalova, A.; Bachleda, P.; Janečková, J.; Panáček, A.; Kvítek, L.; Vrzal, R. The effect of graphene oxide on signalling of xenobiotic receptors involved in biotransformation. Chemosphere 2020, 253, 126753. [CrossRef]

273. Kermanizadeh, A.; Gaiser, B.K.; Johnston, H.; Brown, D.M.; Stone, V. Toxicological effect of engineered nanomaterials on the liver. Br. J. Pharmacol. 2014, 171, 3980-3987. [CrossRef] [PubMed] 
274. Yilmaz, B.; Terekeci, H.; Sandal, S.; Kelestimur, F. Endocrine disrupting chemicals: Exposure, effects on human health, mechanism of action, models for testing and strategies for prevention. Rev. Endocr. Metab. Disord. 2019, 21, 127-147. [CrossRef]

275. Hernandez, J.P.; Huang, W.; Chapman, L.M.; Chua, S.; Moore, D.D.; Baldwin, W.S. The environmental estrogen, nonylphenol, activates the constitutive androstane receptor. Toxicol. Sci. 2007, 98, 416-426. [CrossRef]

276. Toporova, L.; Balaguer, P. Nuclear receptors are the major targets of endocrine disrupting chemicals. Mol. Cell. Endocrinol. 2020, 502, 110665. [CrossRef]

277. Meucci, V.; Arukwe, A. The xenoestrogen 4-nonylphenol modulates hepatic gene expression of pregnane $\mathrm{X}$ receptor, aryl hydrocarbon receptor, CYP3A and CYP1A1 in juvenile Atlantic salmon (Salmo salar). Comp. Biochem. Physiol. Part C: Toxicol. Pharmacol. 2006, 142, 142-150. [CrossRef] [PubMed]

278. Litwa, E.; Kajta, M.; Wnuk, A.; Lasoń, W.; Krzeptowski, W.; Kajta, M. RXR $\alpha$, PXR and CAR xenobiotic receptors mediate the apoptotic and neurotoxic actions of nonylphenol in mouse hippocampal cells. J. Steroid Biochem. Mol. Biol. 2016, 156, 43-52. [CrossRef] [PubMed]

279. Fu, H.; Qiu, S.; Yao, X.; Gao, F.; Tan, P.; Teng, T.; Shi, B. Toxicity of glyphosate in feed for weanling piglets and the mechanism of glyphosate detoxification by the liver nuclear receptor CAR/PXR pathway. J. Hazard. Mater. 2020, 387, 121707. [CrossRef] [PubMed]

280. Xiang, D.; Chu, T.; Li, M.; Wang, Q.; Zhu, G. Effects of pyrethroid pesticide cis-bifenthrin on lipogenesis in hepatic cell line. Chemosphere 2018, 201, 840-849. [CrossRef]

281. Medina-Díaz, I.; Estrada-Muñiz, E.; Reyes-Hernández, O.; Ramírez, P.; Vega, L.; Elizondo, G. Arsenite and its metabolites, MMAIII and DMAIII, modify CYP3A4, PXR and RXR alpha expression in the small intestine of CYP3A4 transgenic mice. Toxicol. Appl. Pharmacol. 2009, 239, 162-168. [CrossRef] [PubMed]

282. Noreault, T.L.; Kostrubsky, V.E.; Wood, S.G.; Nichols, R.C.; Strom, S.C.; Trask, H.W.; Wrighton, S.A.; Evans, R.M.; Jacobs, J.M.; Sinclair, P.R.; et al. Arsenite decreases CYP3A4 and RXRalpha in primary human hepatocytes. Drug Metab. Dispos. 2005, 33, 993-1003. [CrossRef]

283. Liu, G.; Tian, J.; Yin, H.; Yin, J.; Tang, Y. Self-protective transcriptional alterations in ZF4 cells exposed to $\mathrm{Pb}\left(\mathrm{NO}_{3}\right)_{2}$ and $\mathrm{AgNO}_{3}$. J. Biochem. Mol. Toxicol. 2019, 33, e22408. [CrossRef] [PubMed]

284. Li, X.-Y.; Ma, J.; Jing, C.; Wang, J. Expression alterations of cytochromes P4501A1, 2E1, and 3A, and their receptors AhR and PXR caused by 1-octyl-3-methylimidazolium chloride in mouse mammary carcinoma cells. Chemosphere 2013, 93, 2488-2492. [CrossRef]

285. Souidi, M.; Gueguen, Y.; Linard, C.; Dudoignon, N.; Grison, S.; Baudelin, C.; Marquette, C.; Gourmelon, P.; Aigueperse, J.; Dublineau, I. In vivo effects of chronic contamination with depleted uranium on CYP3A and associated nuclear receptors PXR and CAR in the rat. Toxicology 2005, 214, 113-122. [CrossRef]

286. Ayed-Boussema, I.; Pascussi, J.-M.; Maurel, P.; Bacha, H.; Hassen, W. Effect of aflatoxin B1 on nuclear receptors PXR, CAR, and AhR and their target cytochromes P450 mRNA expression in primary cultures of human hepatocytes. Int. J. Toxicol. 2011, 31, 86-93. [CrossRef]

287. Ayed-Boussema, I.; Pascussi, J.-M.; Rjiba, K.; Maurel, P.; Bacha, H.; Hassen, W. The mycotoxin, patulin, increases the expression of PXR and AhR and their target cytochrome P450s in primary cultured human hepatocytes. Drug Chem. Toxicol. 2011, 35, 241-250. [CrossRef]

288. Dořičáková, A.; Vrzal, R. A food contaminant ochratoxin A suppresses pregnane X receptor (PXR)-mediated CYP3A4 induction in primary cultures of human hepatocytes. Toxicology 2015, 337, 72-78. [CrossRef]

289. Shen, Y.; Shi, Z.; Fan, J.T.; Yan, B. Dechlorination and demethylation of ochratoxin A enhance blocking activity of PXR activation, suppress PXR expression and reduce cytotoxicity. Toxicol. Lett. 2020, 332, 171-180. [CrossRef] [PubMed]

290. Renu, K.; Gopalakrishnan, A.V. Deciphering the molecular mechanism during doxorubicin-mediated oxidative stress, apoptosis through Nrf2 and PGC-1 $\alpha$ in a rat testicular milieu. Reprod. Biol. 2019, 19, $22-37$. [CrossRef]

291. Fukumasu, H.; Rochetti, A.L.; Pires, P.R.L.; Da Silva, E.R.; Mesquita, L.G.; Strefezzi, R.; De Carvalho, D.D.; Dagli, M.L.Z. Constitutive androstane receptor ligands modulate the anti-tumor efficacy of paclitaxel in non-small cell lung cancer cells. PLoS ONE 2014, 9, e99484. [CrossRef] [PubMed]

292. Swart, M.; Dandara, C. MicroRNA mediated changes in drug metabolism and target gene expression by efavirenz and rifampicin in vitro: Clinical implications. OMICS A J. Integr. Biol. 2019, 23, 496-507. [CrossRef] 
293. Ku, P.; Wang, C.; Nie, X.; Ou, R.; Li, K. Regulation of pregnane-X-receptor and microRNAs on detoxification-related genes expressions in Mugilogobius abei under the exposure to diclofenac. Environ. Pollut. 2018, 233, 395-406. [CrossRef]

294. Liu, Y.-H.; Mo, S.-L.; Bi, H.; Hu, B.-F.; Li, C.G.; Wang, Y.-T.; Huang, L.; Huang, M.; Duan, W.; Liu, J.-P.; et al. Regulation of human pregnane $X$ receptor and its target gene cytochrome P450 3A4 by Chinese herbal compounds and a molecular docking study. Xenobiotica 2010, 41, 259-280. [CrossRef] [PubMed]

295. Hu, D.; Wang, Y.; Chen, Z.; Ma, Z.; You, Q.; Zhang, X.; Liang, Q.; Tan, H.; Xiao, C.; Tang, X.; et al. The protective effect of piperine on dextran sulfate sodium induced inflammatory bowel disease and its relation with pregnane $X$ receptor activation. J. Ethnopharmacol. 2015, 169, 109-123. [CrossRef] [PubMed]

296. Zhang, X.; Gao, Y.; Wang, Y.; Ma, Z.; Liang, Q.; Tang, X.; Hu, D.; Tan, H.; Xiao, C. Tanshinone IIA ameliorates dextran sulfate sodium-induced inflammatory bowel disease via the pregnane $\mathrm{X}$ receptor. Drug Des. Dev. Ther. 2015, 9, 6343-6362. [CrossRef] [PubMed]

297. Dou, W.; Zhang, J.; Li, H.; Kortagere, S.; Sun, K.; Ding, L.; Ren, G.; Hu, F.; Mani, S. Plant flavonol isorhamnetin attenuates chemically induced inflammatory bowel disease via a PXR-dependent pathway. J. Nutr. Biochem. 2014, 25, 923-933. [CrossRef]

298. Juan, Y.-C.; Chang, C.-C.; Tsai, W.-J.; Lin, Y.-L.; Hsu, Y.-S.; Liu, H.-K. Pharmacological evaluation of insulin mimetic novel suppressors of PEPCK gene transcription from Paeoniae Rubra Radix. J. Ethnopharmacol. 2011, 137, 592-600. [CrossRef]

299. Murali, G.; Milne, G.L.; Webb, C.D.; Stewart, A.B.; McMillan, R.P.; Lyle, B.C.; Hulver, M.W.; Saraswathi, V. Fish oil and indomethacin in combination potently reduce dyslipidemia and hepatic steatosis in LDLR(-/-) mice. J. Lipid Res. 2012, 53, 2186-2197. [CrossRef]

300. Saraswathi, V.; Perriotte-Olson, C.; Ganesan, M.; DeSouza, C.V.; Alnouti, Y.; Duryee, M.J.; Thiele, G.M.; Nordgren, T.M.; Clemens, D.L. A combination of dietary N-3 fatty acids and a cyclooxygenase-1 inhibitor attenuates nonalcoholic fatty liver disease in mice. J. Nutr. Biochem. 2017, 42, 149-159. [CrossRef]

301. He, L.; Li, H.; Huang, N.; Zhou, X.; Tian, J.; Li, T.; Wu, J.; Tian, Y.; Yin, Y.; Yao, K. Alpha-ketoglutarate suppresses the NF-kB-mediated inflammatory pathway and enhances the PXR-regulated detoxification pathway. Oncotarget 2017, 8, 102974-102988. [CrossRef] [PubMed]

302. Fu, L.; Zhou, L.; Geng, S.; Li, M.; Lu, W.; Lu, Y.; Feng, Z.; Zhou, X. Catalpol coordinately regulates phase I and II detoxification enzymes of Triptolide through CAR and NRF2 pathways to reduce Triptolide-induced hepatotoxicity. Biomed. Pharmacother. 2020, 129, 110379. [CrossRef] [PubMed]

303. Radović, B.; Hussong, R.; Gerhäuser, C.; Meinl, W.; Frank, N.; Becker, H.; Köhrle, J. Xanthohumol, a prenylated chalcone from hops, modulates hepatic expression of genes involved in thyroid hormone distribution and metabolism. Mol. Nutr. Food Res. 2010, 54, S225-S235. [CrossRef]

304. Xu, H.-B.; Tang, Z.-Q.; Wang, J.; Kong, P.-S. Z-guggulsterone regulates MDR1 expression mainly through the pregnane $X$ receptor-dependent manner in human brain microvessel endothelial cells. Eur. J. Pharmacol. 2020, 874, 173023. [CrossRef] [PubMed]

305. Fukumasu, H.; Rochetti, A.L.; Latorre, A.O.; Pires, P.R.L.; Silva, T.C.; Dagli, M.L.Z. Caffeine increases Nr1i3 expression and potentiates the effects of its ligand, TCPOBOP, in mice liver. Braz. J. Pharm. Sci. 2015, 51, 295-303. [CrossRef]

306. Noreault, T.L.; Jacobs, J.M.; Nichols, R.C.; Trask, H.W.; Wrighton, S.A.; Sinclair, P.R.; Sinclair, J.F. Mechanism of arsenite-mediated decreases in CYP3A23 in rat hepatocytes. Biochem. Biophys. Res. Commun. 2005, 333, 1211-1217. [CrossRef]

307. Chai, S.C.; Cherian, M.T.; Wang, Y.-M.; Chen, T. Small-molecule modulators of PXR and CAR. Biochim. Biophys. Acta (BBA) Bioenerg. 2016, 1859, 1141-1154. [CrossRef]

Publisher's Note: MDPI stays neutral with regard to jurisdictional claims in published maps and institutional affiliations. 